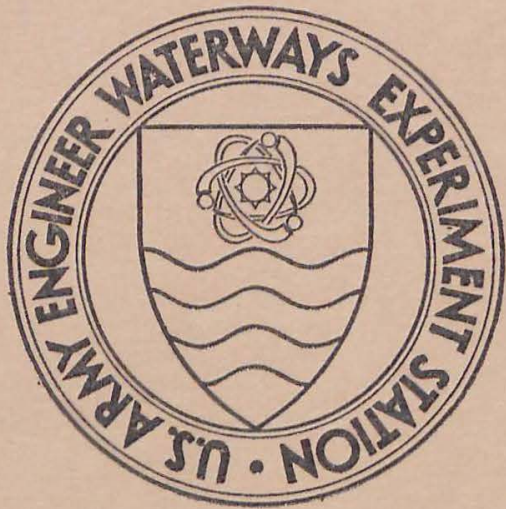

MISCELLANEOUS PAPER M-74-1

\title{
A LIMITED STUDY OF THE PERFORMANCE OF AN INTERIM 3/4-TON WHEEL/TRACK CONVERTIBLE TEST RIG, HOUGHTON, MICHIGAN, AND VICKSBURG, MISSISSIPPI \\ by
}

W. E. Willoughby

\section{11}

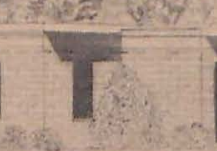

April 1974

Sponsored by U. S. Army Materiel Command and

U. S. Army Tank-Automotive Command

Conducted by U. S. Army Engineer Waterways Experiment Station

Mobility and Environmental Systems Laboratory

Vicksburg, Mississippi 
Destroy this report when no longer needed. Do not return it to the originator.

The findings in this report are not to be construed as an official

Department of the Army position unless so designated by other authorized documents. 


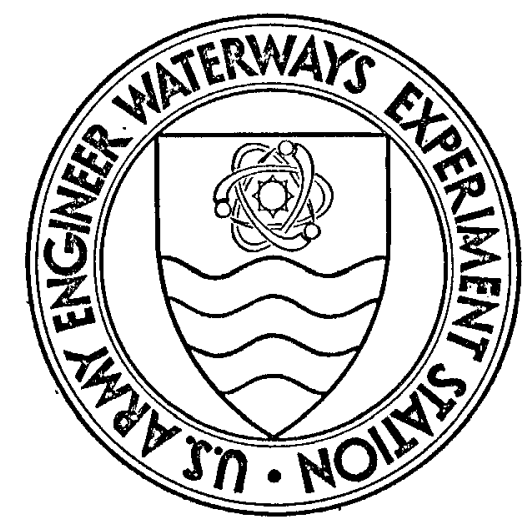

MISCELLANEOUS PAPER M-74-1

\section{A LIMITED STUDY OF THE PERFORMANCE OF AN INTERIM 3/4-TON WHEEL/TRACK CONVERTIBLE TEST RIG, HOUGHTON, MICHIGAN, AND VICKSBURG, MISSISSIPPI by}

W. E. Willoughby

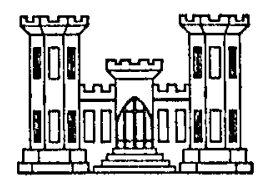

April 1974

Sponsored by U. S. Army Materiel Command and

U. S. Army Tank-Automotive Command

Conducted by U. S. Army Engineer Waterways Experiment Station

Mobility and Environmental Systems Laboratory

Vicksburg, Mississippi 

THE CONTENTS OF THIS REPORT ARE NOT TO BE USED FOR ADVERTISING, PUBLICATION, OR PROMOTIONAI PURPOSES. CITATION OF TRADE ILAMES DOES NOT CONSTITUTE AN OFFICIAI ENDORSEMENT OR APPROVAL OF THE USE OF SUCH COMMERCIAL PRODUCTS. 



\section{FOREWORD}

The test program reported herein was requested by Headquarters, U. S. Army Materiel Command and funded through the U. S. Army TankAutomotive Command (TACOM) by Intra-Army Order for Reimbursable Services, No. 72-3R, dated 14 June 1972. It was conducted during MayOctober 1973 by personne1 of the U. S. Army Engineer Waterways Experiment Station (WES) and TACOM under the general supervision of Messrs. W. G. Shockley, Chief of the Mobility and Environmental Systems Laboratory (MESL), WES; A. A. Rula, Chief of the Mobility Systems Division (MSD), MESL; and E. S. Rush, Chief of the Mobility Investigations Branch (MIB), MSD; and Tibor Czako, Surface Mobility Division, TACOM. Field tests were performed near Houghton, Michigan, and Vicksburg, Mississippi, under the direction of Messrs. W. E. Willoughby of the MIB and J. F. Kopera, Concept and Technology Division, TACOM. Mr. Willoughby prepared this report.

Acknowledgments are made to personne1 of TACOM, builders of the test rig, and of Keweenaw Field Station at Houghton for assistance and support during the tests.

COL G. H. Hilt, CE, was Director of the WES during the test program and preparation of the report. Mr. F. R. Brown was Technical Director. 

CONTENTS

$\underline{\text { Page }}$

FOREWORD . . . . . . . . . . . . . . . . . . V v

CONVERSION FACTORS, BRITISH TO METRIC AND METRIC TO BRITISH

UNITS OF MEASUREMENT . . . . . . . . . . . . . . . . . . . . ix

SUMMARY . . . . . . . . . . . . . . . . . . . . xi

PART I: INTRODUCTION . . . . . . . . . . . . . . . I I

Background . . . . . . . . . . . . . . . . . 1

Purpose and Scope .................... 2

Definitions . . . . . . . . . . . . . . . . . 2

PART II: TEST PROGRAM AT HOUGHTON, MICHIGAN . . . . . . . . ID

Description of Test Sites . . . . . . . . . . . . 12

Test Vehicles . . . . . . . . . . . . . . . . . . 17

Tests Conducted, Procedures, and Data Collected . . . . 21

PART III: TEST PROGRAM AT VICKSBURG, MISSISSIPPI . . . . . . 30

Description of Test Sites . . . . . . . . . 30

Test Vehicles... . . . . . . . . . . . 32

Tests Conducted, Procedures, and Data Collected . . . . . 32

PART IV: ANALYSIS OF DATA . . . . . . . . . . . . . 40

Tests at Houghton, Michigan . . . . . . . . . . 40

Tests at Vicksburg, Mississippi . . . . . . . . . . 44

PART V: CONCLUSIONS AND RECOMMENDATIONS . . . . . . . . . 48

Conclusions .................... . . 48

Recommendations . . . . . . . . . . . . . 49

TABLES $1-12$

APPENDIX A: TEST PLAN FOR WHEEL/TRACK CONVERTIBLE TEST

RIG, 3/4-TON . . . . . . . . . . . . . . . AI

Background . . . . . . . . . . . . . . . . . . Al

Status . . . . . . . . . . . . . . . . . . Al

Objective . . . . . . . . . . . . . . . . . $\mathrm{A} 2$

Scope . . . . . . . . . . . . . . . . . . A2

Test Vehicles . . . . . . . . . . . . . . . . . A3

Test Areas . . . . . . . . . . . . . . . . . . A3

Test Program . . . . . . . . . . . . . . . . A6

Test Schedule and Cost . . . . . . . . . . . . Al5

TABLES Al-AII 

CONVERSION FACTORS, BRITISH TO METRIC AND METRIC TO BRITISH UNITS OF MEASUREMENT

Units of measurement used in this report can be converted as follows:

\begin{tabular}{|c|c|c|}
\hline Multiply & by & To Obtain \\
\hline & British to Metric & \\
\hline inches & 25.4 & millimeters \\
\hline feet & 0.3048 & meters \\
\hline feet per minute & 0.3048 & meters per minute \\
\hline pounds (mass) & 0.45359 & kilograms \\
\hline pounds (force) & 4.4482 & newtons \\
\hline tons $(2000 \mathrm{lb})$ & 907.185 & kilograms \\
\hline square inches & 645.16 & square mil1imeters \\
\hline pounds per square inch & 6.894757 & kilopascals \\
\hline pounds per cubic foot & 0.0160 & grams per cubic centimeter \\
\hline miles per hour & 1.609344 & kilometers per hour \\
\hline miles (U. S. statute) & 1.6093 & kilometers \\
\hline cubic inches & 16.3871 & cubic centimeters \\
\hline \multicolumn{3}{|c|}{ Metric to British } \\
\hline millimeters & 0.0394 & inches \\
\hline centimeters & 0.3937 & inches \\
\hline
\end{tabular}



SUMMARY

The interim Wheel/Track Convertible Test Rig, a uniquely suspended $8 \times 8$ wheeled vehicle that uses wrap-around tracks for improved performance, was tested in a variety of terrain conditions at Houghton, Michigan, and at Vicksburg, Mississippi, and in soil bins in a facility at Vicksburg. Tests were conducted to: evaluate the feasibility of the concept, determine if the track would stay on, observe interaction at the wheel-track interface to determine any possible slippage, determine ride and handling characteristics of the Wheel/Track Test Rig, which uses powered road arm suspensions, and evaluate and compare performance of the Test Rig with that of other available vehicles in tests on trails, cross-country traverses, special terrain, and laboratoryprepared soils.

The Wheel/Track Test Rig performed well in a variety of terrain conditions; generally its performance equaled or exceeded the performance of both wheeled and tracked comparison vehicles. Vehicle ride and handling characteristics were considered better than those of the comparison vehicles. Test rig performance in soil in the wheel mode was impressive: a drawbar pull/weight coefficient of 0.96 was obtained on a clay soil prepared in the laboratory to a strength of $66 \mathrm{RCI}$, and a field experimental one-pass vehicle cone index of 11 was obtained. No whee1-track slip occurred during any of these tests, including tests on soft buckshot clay in which the vehicle running gear accumulated $16001 \mathrm{~b}$ of mud (on a 6700-1b vehicle).

Based on these tests, the Wheel/Track Convertible locomotion system is practicable, and the ride, handling, and performance of the Wheel/Track Test Rig suggest advanced testing, following any future design modifications.

Appendix A presents the plan of tests followed in this program. 


\section{A LIMITED STUDY OF THE PERFORMANCE OF AN INTERIM}

3/4-TON WHEEL/TRACK CONVERTIBLE TEST RIG

HOUGHTON, MICHIGAN, AND VICKSBURG, MISSISSIPPI

PART I: INTRODUCTION

\section{$\underline{\text { Background }}$}

1. An exploratory development effort was initiated by the U. S. Army Tank-Automotive Command (TACOM) in fiscal year 1972 to determine the feasibility of using a wheel/track convertible concept to attain a major improvement in off-road surface mobility and tactical and logistical flexibility. The original concept was an $8 \times 8$ wheeled vehicle with infinite-variable-ratio steering. It could be readily converted to a tracked vehicle for soft-soil and snow mobility whenever the season or major terrain area required. An interim 3/4-ton* test rig powered by a differential-gear-steered power train was subsequent1y designed and fabricated by TACOM to assess the critical wheel-track interface, the unique integrated drive and trailing arm suspension system, and the skid-steer handling of the wheeled version. Upon satisfactory completion of the feasibility evaluation, it is tentatively planned to install a hydromechanical power train to assess the remaining critical area, that of high road speed-infinite variable ratio steer performance. This final configuration may satisfy Alaskan and infantry draft-load carrier requirements and future needs for highmobility utility vehicles. This report covers the tests with the interim differential-gear-steered Test Rig, hereafter called Wheel/Track Convertible Test Rig, or simply Test Rig.

* A table of factors for converting British units of measurement to metric units and metric units to British units is given on page ix. 


\section{Purpose and Scope}

2. During May-October 1973, personnel of the U. S. Army Engineer Waterways Experiment Station (WES) and of TACOM conducted tests at Houghton, Michigan, and Vicksburg, Mississippi, to evaluate the practicability of the Wheel/Track Convertible Test Rig operating in various running-gear configurations and ground surface conditions and to compare its performance with that of several conventional wheeled and tracked vehicles. Appropriate data and test notes were recorded for each test configuration and surface condition to permit full evaluation of the Test Rig. The U. S. Army Materiel Command Ground Mobility Model (AMC-71)* was used as a basis for collecting vegetation and vehicle performance data. Results of the tests are summarized in this report. The requirements for a vehicle for which the Test Rig is a candidate are discussed in the background of the Test Plan for Wheel/Track Convertible Test Rig, 3/4-Ton (Appendix A).

\section{Definitions}

3. Certain special terms used in this report are defined below. a. General terms

(1) Ground mobility. The ability of a ground contact vehicle to move across a landscape without benefit of roads or engineering assistance. Thus, a measure of ground mobility is a measure of the vehicle-terrain interaction.

(2) Trafficability test. A test conducted in a homogeneous area at low speeds to determine vehicle-terrain relations.

(3) Mobility test. A test to determine vehicle "speedmade-good" along a traverse consisting of two or more

* U. S. Army Tank-Automotive Command, "The AMC '71 Mobility Model," Technical Report 11789 (LL 143), Jul 1973, Warren, Mich. 
contiguous terrain or road units. Speed-made-good is computed by dividing the time required by a vehicle to complete a traverse into the straight-1ine distance between the beginning and end points of the traverse.

b. Soil terms

(1) Unified Soil Classification System (USCS). A soil classification system based on identification of soils according to their textural and plasticity qualities and on their grouping with respect to their engineering behavior.

(2) U. S. Department of Agriculture (USDA) Classification System. A soil classification system developed by the United States Department of Agriculture based on identification of soils according to grain sizes or the relative proportions of the sand, silt, and clay fractions, each term being defined as a specific range of sizes.

(3) Fine-grained soi1. A soil of which more than 50 percent (by weight) of the grains will pass a No. 200 U. S. standard sieve (grains smaller than $0.074 \mathrm{~mm}$ in diameter).

(4) Coarse-grained soil. A soil of which more than 50 percent (by weight) of the grains will be retained on a No. 200 sieve (grains larger than $0.074 \mathrm{~mm}$ in diameter).

(5) Organic soil. The living, dying, and dead vegetation that forms a surface mat and the mixture of partially decomposed and disintegrated organic material (commonly known as peat or muck) below the surface mat. Small quantities of mineral soil may or may not be mixed with the organic material. 
(6) Radforth Classification System. A widely used muskeg classification system first proposed by Dr. N. W. Radforth of Canada in 1952. The living vegetal cover is designated by a combination of capital letters, with each letter representing a particular botanical group and the letters listed in order of prominence of the particular group.

(7) Stamped "sand." Bedrock crushed or stamped to the texture and size of coarse-grained soils during copper mining operations and subsequently deposited hydraulically in depressions near the stamping mills.

\section{c. Soil strength terms}

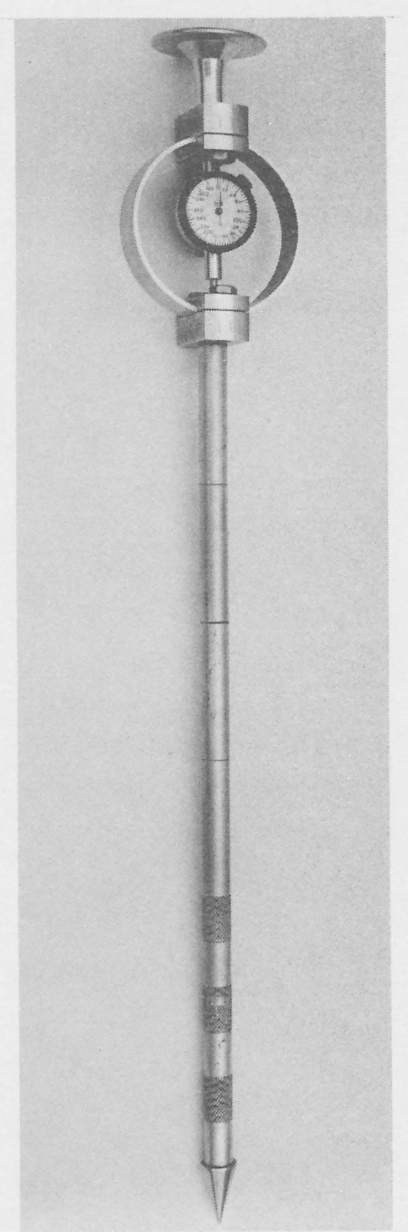

Fig. 1. Cone penetrometer
(1) Cone index (CI). An index of the shearing resistance of a medium obtained with a cone penetrometer (fig. 1). The value obtained represents the vertical resistance of the medium to penetration at $6 \mathrm{ft} / \mathrm{min}$ of a 30deg cone of 0.5 -sq-in.-base or projected area. The value, although usually considered dimensionless in trafficability studies, actually denotes pounds of force on the handle divided by the area of the cone base in square inches (i.e. pounds per square inch).

(2) Remolding index (RI). A ratio that expresses the proportion of the original strength of a soil that will be retained after traffic of a moving vehicle. The ratio is determined from cone index measurements made before and after remolding a 6-in.-long sample using the equipment shown in fig. 2. The test sample is obtained with a trafficability sampler (fig. 3). 
Fig. 2. Remolding equipment and cone penetrometer
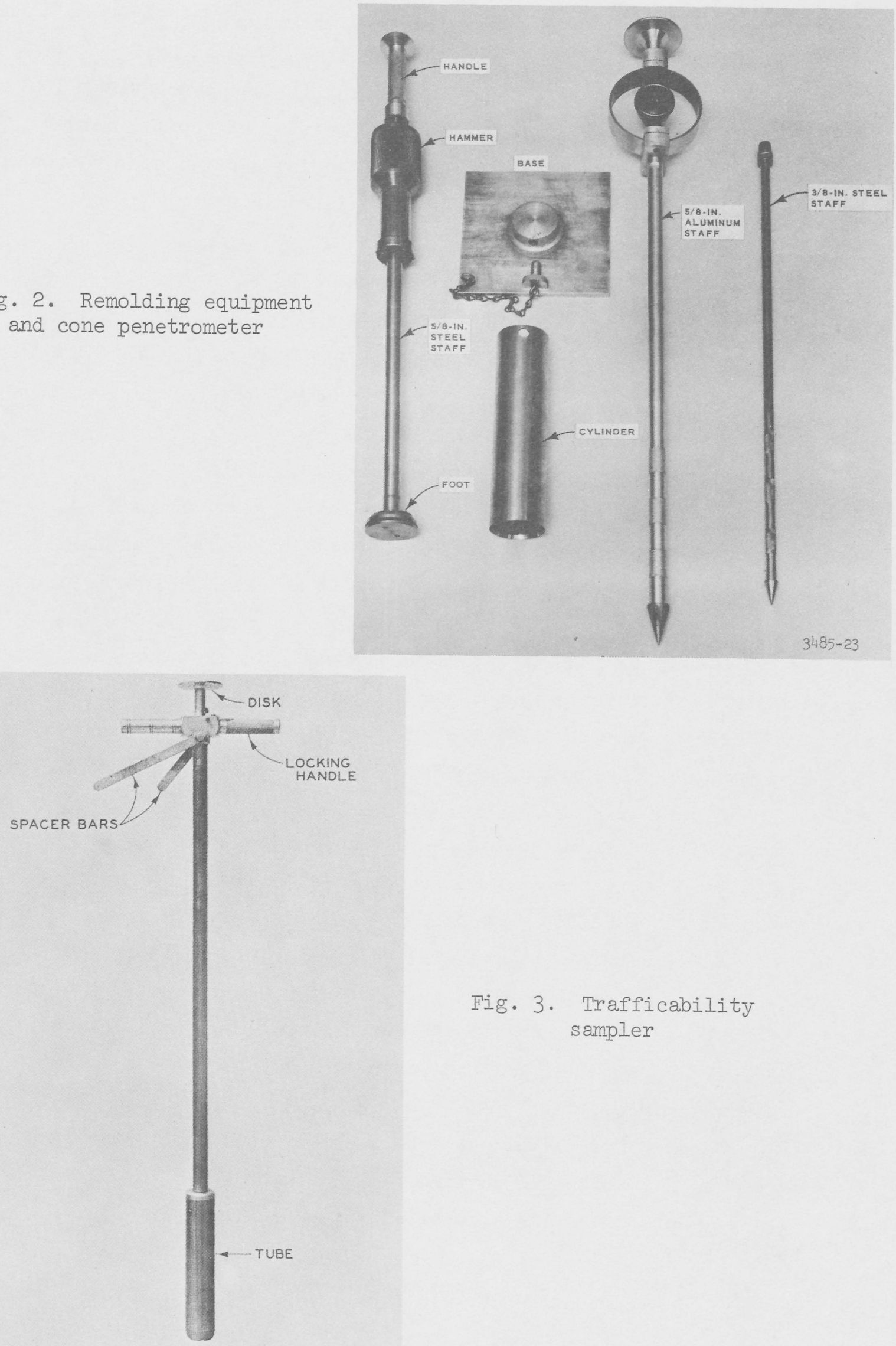

Fig. 3. Trafficability sampler 
(3) Rating cone index (RCI) . The product of the remolding index and the average of the measured in situ cone index for the same layer of soil. The index is valid only for fine-grained soils and sands with fines, poorly drained.

d. Terrain terms

(1) Terrain factor. Any attribute of the terrain that can adequately be described at any point (or instant of time) by a single measurable value; for example, slope or obstacle height.

(2) Terrain factor value. A specific occurrence of a terrain factor. For example, 2 percent is a factor value of the terrain factor slope.

(3) Terrain factor class (class range). A specified range of factor values established for a specific purpose; for example, a range of slope from 0 to 2 percent.

(4) Terrain factor class number. A number assigned to a terrain factor class range. For mobility purposes, terrain factor class numbers are assigned in order of increasing severity of effect on vehicle performance (fig. 4).

(5) Terrain factor complex number. A combination of two or more terrain factor class numbers chosen for a specific purpose.

(6) Terrain unit. A patch (areal) or length (linear) of terrain assumed to be homogeneous in terms of specific terrain factors and normally described by a specific array of terrain factor class numbers.

e. Vehicle terms

(1) Immobilization. The inability of a self-propelled vehicle to go forward or backward.

(2) Pass. One trip of a vehicle over a test course. 


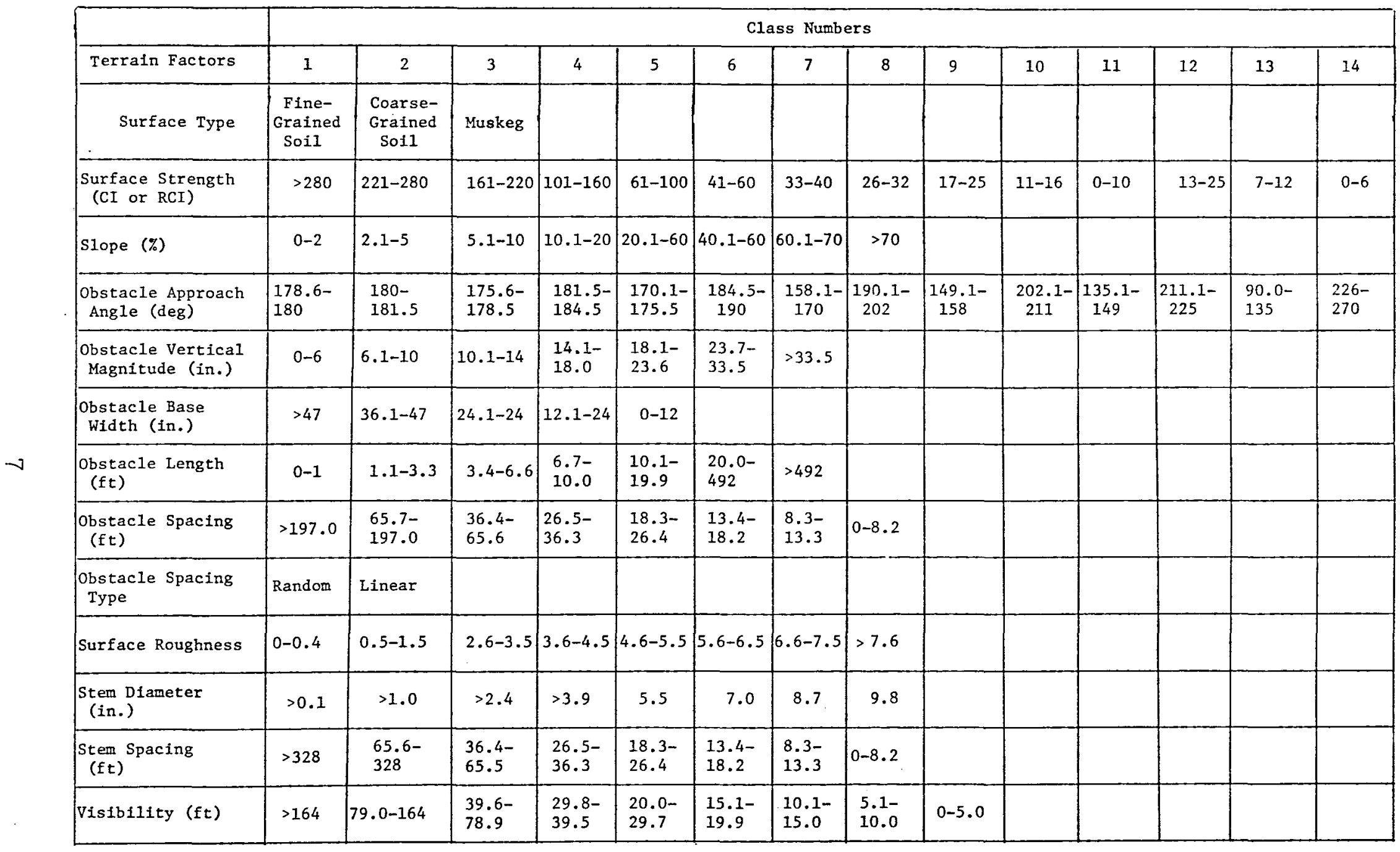

Fig. 4. Areal terrain factor class numbers 
(3) Multiple passes. More than one trip of a vehicle in the same path over the test course.

(4) Mobility index. A dimensionless number that results from a consideration of certain vehicle characteristics. It is used to obtain an estimate of the vehicle cone index.

(5) Vehicle cone index (VCI). The minimum rating cone index (RCI) that will permit a vehicle to complete a specified number of passes; thus, $V I_{50}$ means the minimum RCI necessary to complete 50 passes, and $\mathrm{VCI}_{1}$ means the minimum RCI necessary to complete one pass.

(6) Maximum drawbar pu11. The maximum amount of sustained towing force a self-propelled vehicle can produce at its drawbar under given test conditions.

(7) Drawbar-pu11 coefficient at 20 percent $\operatorname{silp}\left(\mathrm{D} / \mathrm{W}_{20}\right)$.

The amount of drawbar pull developed by a vehicle at 20 percent vehicle slip, expressed as a percentage of the vehicle test weight.

(8) Towed motion resistance. The amount of force required to tow a test vehicle in neutral gear under given test conditions.

(9) Slip. The percentage of track or wheel movement ineffective in thrusting a vehicle forward.

(10) Ride. The quality of vibratory motions caused by random terrain irregularities as sensed by a vehicle occupant.

(11) Absorbed power. The rate at which vibrational energy is absorbed by a vehicle occupant. It is a measure of ride quality.

f. Surface geometry terms

(1) Slope or macrogeometry. The angular deviation of a surface from the horizontal, expressed as a percentage. 
(2) Surface roughness or microgeometry. Microvariations of the terrain surface that adversely affect vehicle ride dynamics.

(3) Root mean square (rms) elevation. A measure of surface roughness expressed as the root mean square deviation of the terrain amplitudes of a microsurface profile from the mean. (Because peculiarities occur in natural terrain microprofiles, special data hand1ing techniques are used in preprocessing the profile data.)

\section{g. Vegetation terms}

(1) Stem diameter. The diameter of the tree stems at breast height ( $4.5 \mathrm{ft}$ ) above the ground.

(2) Stem spacing. The average distance between tree stems. This value is computed from the number of stems per unit area.

(3) Recognition distance or visibility. The distance at which a vehicle driver can see and recognize objects that may be hazardous to his vehicle or to himself. 
4. The test sites were located generally in the central portion of the Keweenaw Peninsula of upper Michigan, as shown in fig. 5. The area is representative of the wide variation in topography formed in resistant Pre-Cambrian bedrock and modified by Pleistocene glacial processes. The principal effect of this glaciation on topography was a leveling of the surface by the filling of depressions and the erosion of less resistant bedrock by glacial scour. Generally, the unweathered surface is flat to rolling with scattered knobs, kettles, minor ridges with relief of less than $75 \mathrm{ft}$, and pitted outwash plains. Glacial deposition types are mainly moraines, tills or ground moraines, outwashes, and glacio-lacustrine deposits. Most of the higher areas are parallel to the consequent drainage pattern that has developed along zones of weaker bedrock. The lower areas are filled with coarse and fine sands and silts of probable glacio-lacustrine origin. Principal soil types of the higher areas are of the Keweenaw-Munising-Kalkaska association (USDA classification) characterized by we11-drained sandy loam glacial tills derived from reddish acid sandstones. The lower areas are of the Gay association of poorly drained soils in depressions with organic surface layers. Access is generally poor throughout the area because of heavy forest cover and a low stream gradient that produces widespread swampy conditions. A dense second growth of northern hardwoods, principally maple, birch, elm, poplar, ash, hemlock, and fir, covers most of the higher terrain. The poorly drained lower areas are characterized by swamps and organic bogs with high water tables. Heavy growth of moss and lichens covers most of the sandy open areas.

5. Precipitation is generally heavy, with yearly normals of 35 in. of rain and more than 100 in. of snow and sleet. Temperatures range from a mean of $10 \mathrm{~F}$ in January to a mean maximum of $73 \mathrm{~F}$ in July.

6. A majority of the inhabitants are scattered throughout sma11 villages that sprang up around copper mining operations about 1900 . Most of the land is still owned by either copper or lumber interests, 


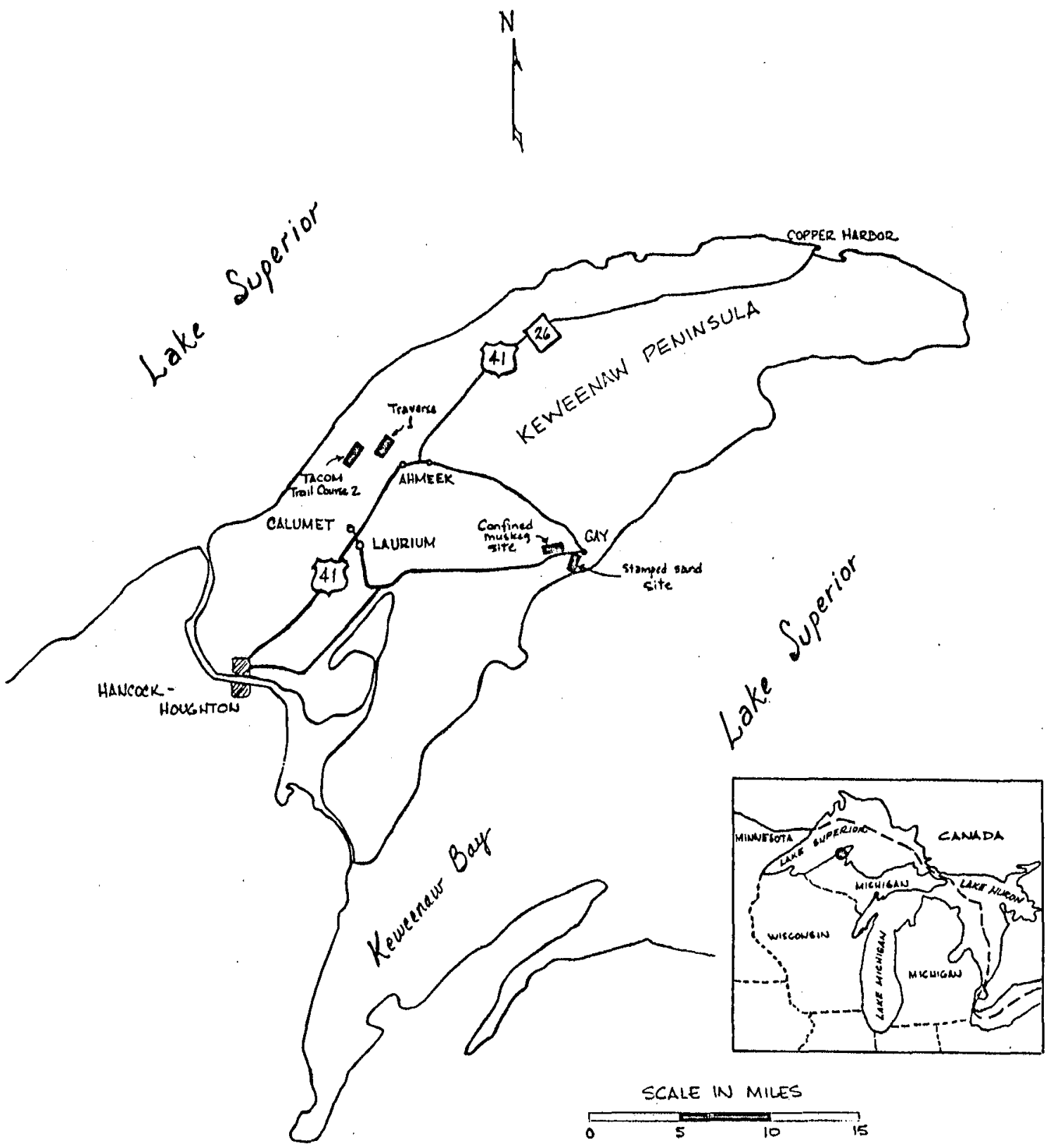

Fig. 5. Location of test sites in Upper Peninsula of Michigan 
which purchased the area for its products. Copper operations are now only minimal, having peaked during World War II, but forestry and agriculture are still important. A major source of revenue is tourists, drawn to the area by its natural beauty, serenity, winter sports, and proximity to Isle Royale National Park.

\section{Description of Test Sites}

7. Three types of tests were conducted in the Houghton area: trail, cross-country, and special-terrain. One trail course (TACOM Trail Course 2) selected near Ahmeek (fig. 5) was composed of various combinations of slope, microgeometry, vegetation (bordering trail), and surface conditions. One cross-country traverse selected in the Ahmeek area was composed of various combinations of microgeometry, vegetation, and surface conditions. Two special terrains were used, one composed of organic soil (muskeg) and the other of crushed rock of the size and texture of coarse-grained sand (stamped sand); both were in the general vicinity of Gay, Michigan (fig. 5). The crushed rock is actually a large deposit of crushed mine tailings from copper mine operations at the old Mohawk Mill at Gay, subsequently deposited on the nearby Lake Superior shore.

TACOM Trail Course 2, Ahmeek, Michigan

8. Located 3 miles northwest of Ahmeek (see fig. 5), TACOM Trail Course 2 (fig. 6) had been used in the past by TACOM in vehicle trail tests. Initially, WES personnel surveyed the 15,000-ft course to obtain a ground-surface profile (fig. 7) to aid in terrain unit selection. After the profile was plotted, the trail course was divided into 18 distinct terrain units based on variations in surface geometry, strength, vegetation, slope, or linear features (such as streams). The trail was about $10 \mathrm{ft}$ wide and ran through woody areas where trees bordered the trail, affecting vehicle performance, and through open areas. Dominant soil type is Kalhaska sand, which ranges from nearly pure sand to light, loamy sand in colors of gray and brown. The low fertility of this sand, 


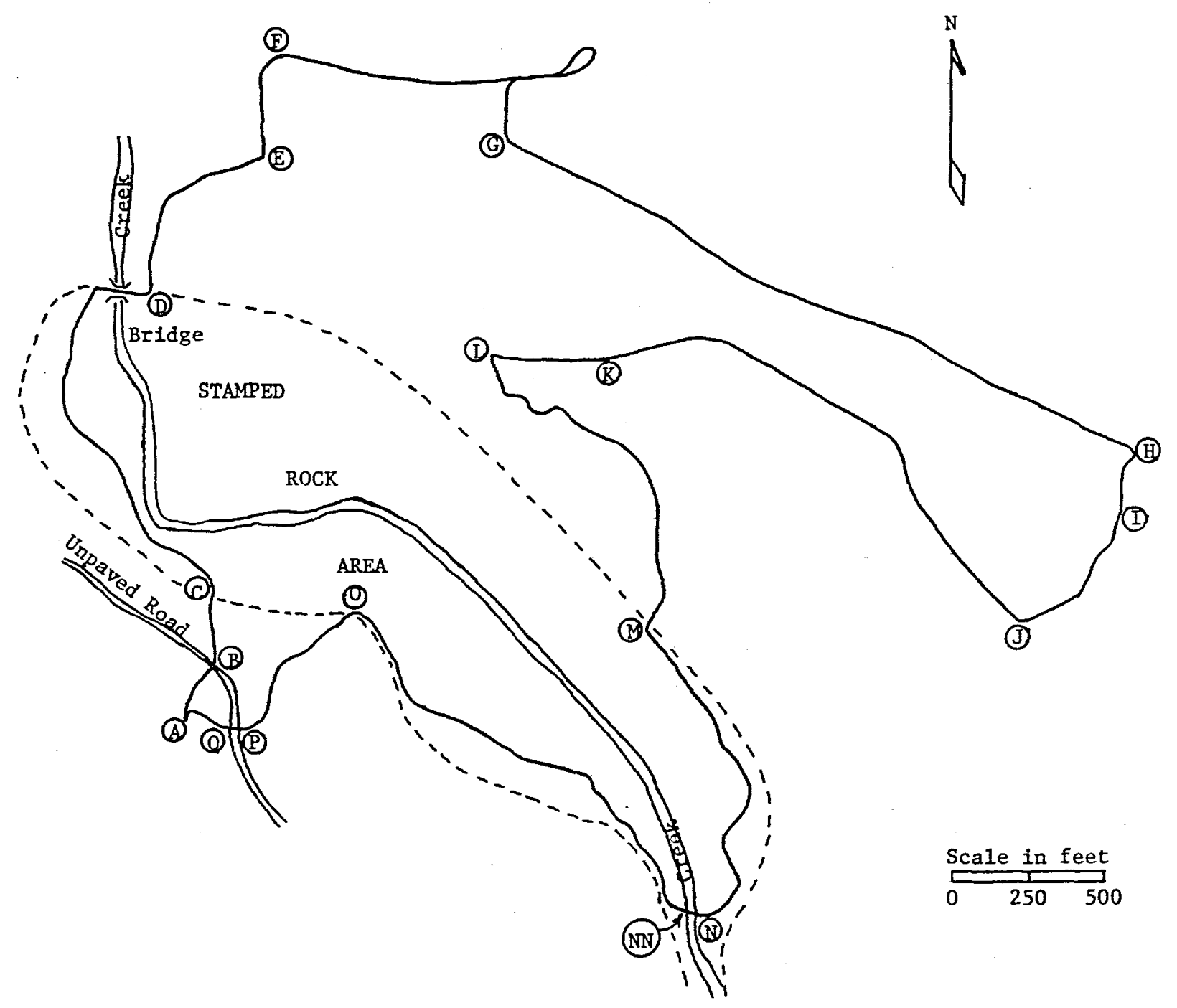

Fig. 6. Plan view, TACOM Trail Course 2, Houghton, Michigan 

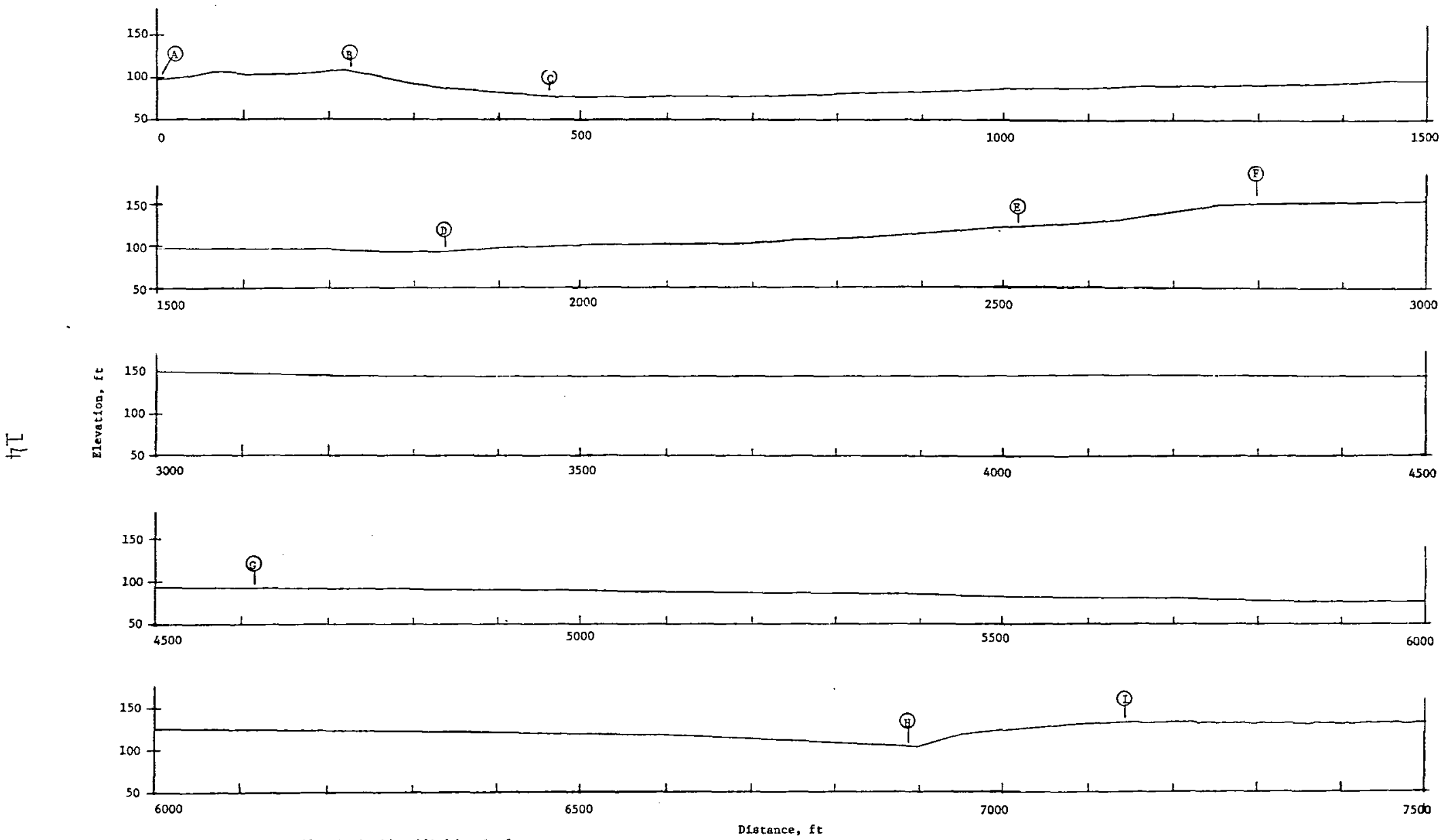

NoTE: Each trail unit is 1dentified by the letter at its beginning, e.g. unft $A-B$ is destgrated

Fig. 7. Surface profile, TACOM Trail Course 2, Houghton, Michigan, 1/2 in. = 100 ft (Continued) 

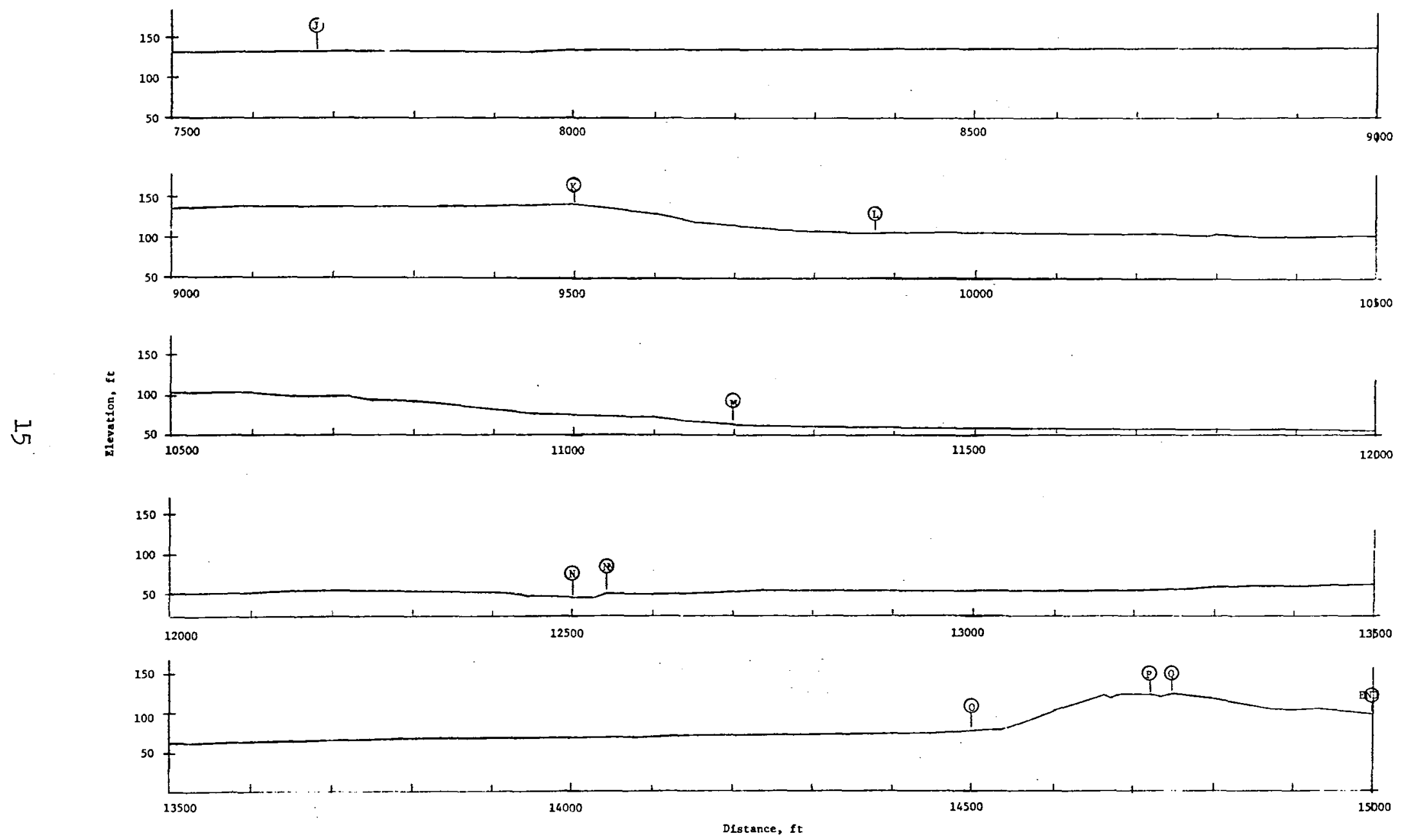

Fig. 7. (Concluded) 
combined with the relatively dense crown growths of maples and pines, allows only limited ground-cover growth. Therefore, most of the trail areas are relatively barren, except in the woody areas where ground litter obscures the sand surface or rocks cover the trail surface. On portions of the course, the trail crosses areas of stamped, coarse-sandsize rock remaining from the copper mining operations in the area. These areas are relatively barren, with sand colors ranging from gray to pink depending on the parent bedrock from which they were stamped. The stamped areas on this course are also littered with logs and stumps from logging operations in the area. One fordable creek and several bisecting, sandy tertiary roads intersect the trail at several points.

9. The wide variety of terrain factors affecting vehicle performance, along with their varying effects on tracked and wheeled systems, combined to create a useful test of these systems in the various environmental conditions on this course. Terrain data collection methods used for this report followed techniques described in detail for computer input to the AMC-71 Ground Mobili.ty Mode1.* The various terrain descriptors were collected and summarized in the form of table 1. Traverse 1, Ahmeek, Michigan

10. Traverse 1, located 1 mile northwest of Ahmeek (fig. 5), was short (2346 ft in length) and rough. The entire area is harshly glaciated with random rounded and traverse ridges and abrupt irregular ditches. The main soil type is gray Kalhaska sand with some loam mixed. There were three terrain units in this traverse. The first was $550 \mathrm{ft}$ long, relatively rough and open with lichens and grasses for surface cover. The second was $750 \mathrm{ft}$ of gradually rolling terrain, with a 3-ft-high, 200-ft-diam shrub-covered knoll the dominant surface feature. The small shrubs hindered visibility slightly and increased the maneuvering required to traverse the unit. Lichens, grasses, and scattered blueberry patches interspersed in the rocky, sandy soil provided surface cover. The third unit comprised the last $1046 \mathrm{ft}$ of the traverse.

* Ibid., page 2 . 
It was an extremely rough, open area of lichens, grasses, scattered shrubs, stumps, and blueberry patches, and was the roughest unit of the three with respect to surface geometry.

11. The environmental factor that limited vehicle speed over the entire traverse was surface roughness. The few shrubs and stumps required some vehicle maneuvering, but the vehicle speeds were definitely limited by ride quality.

Confined muskeg site, Gay, Michigan

12. The confined muskeg site was 1 mile west of Gay, Michigan (fig. 5), and 2 miles northwest of the other test site at Gay. The area was composed of nonwoody vegetation and grass (classified FI by the Radforth Classification System) with some widely scattered scrub trees. Organic material in the area varies from 6 to $13 \mathrm{ft}$ deep. Stamped-sand site, Gay, Michigan

13. Located 1 mile south of Gay, Michigan (fig. 5), the stampedsand site is dry and barren and composed of gray, stamped rock of the size and texture of coarse sand, a by-product of the copper industry in the area. The gray color is derived from the parent bedrock stamped to coarse-sand size in copper mining operations. These mine tailings were hydraulically deposited on the Lake Superior shore by the old Mohawk Mi11 at Gay. This coarse-sand area was used for slope tests. Littoral drift had separated the finer particles and deposited them southwest of their original deposition. This fine-sand area was used for maximumdrawbar-pull, towed-motion-resistance, and speed tests.

\section{Test Vehicles}

14. Vehicle characteristics of the Wheel/Track Convertible Test Rig are presented in fig. 8; various views of the Test Rig in both the wheeled and the tracked mode are shown in fig. 9. Vehicles used for comparisons in the test program (fig. 10) were those that were readily available and could accommodate cross-country payloads of $1 / 4-5 / 4$ tons. 
Vehicle Characteristics - Wheel/Track Test Rig

Engine - 289-cu-in. Ford, V8, water-cooled, gasoline

Transmission - Ford 3-speed automatic

Cross drive - Bowen DS-50

Suspension - Independent, torsilastic

Gross Weight (wheeled mode) - $5600 \mathrm{Ib}$

Gross Weight (tracked mode) - $6700 \mathrm{lb}$

Tires - Goodyear, Terra, 26×12-12,

chevron grip

Track width -15.25 in.

Clearance - 14 in.

Flotation - 2.6-in. freeboard to deck

Speed range - 0-40 mph (offroad)

Vehicle cone index - 11, wheeied; 9, tracked

Ground contact presisure -8.9 psi, wheeled; 3.4 psi, tracked

(Roll bars added to vehicle as safety precaution are

is not shown,)

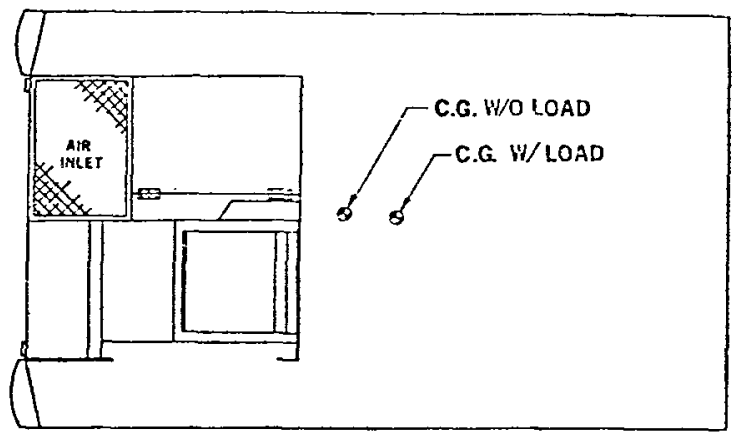

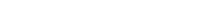
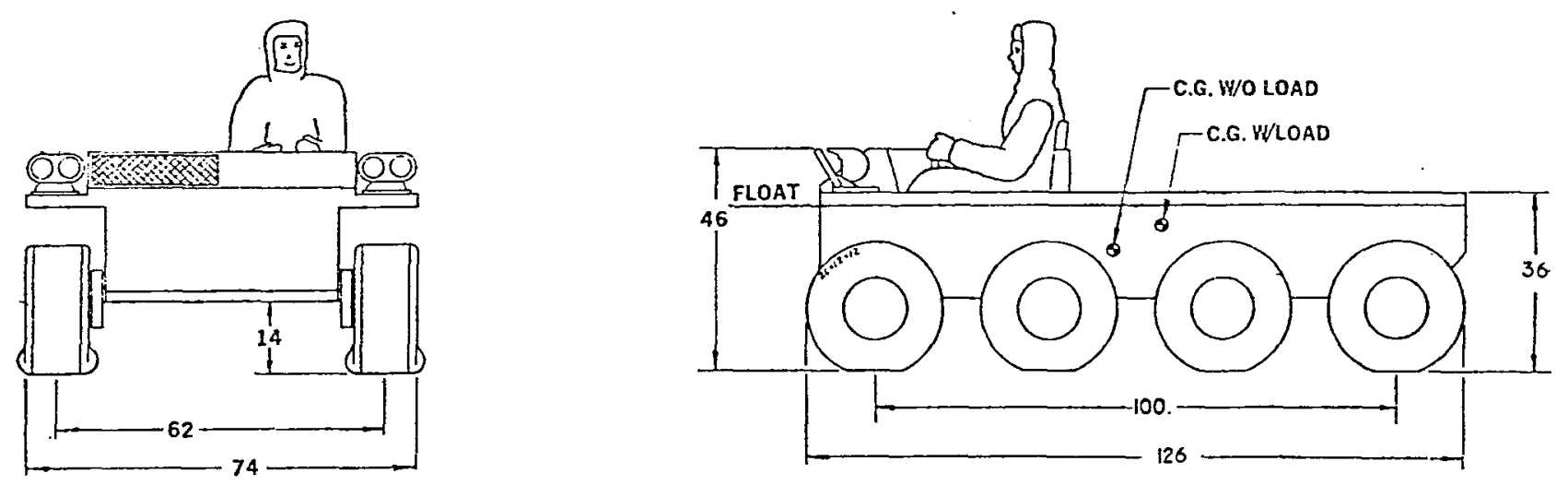

Fig. 8. Wheel/Track Convertible Test Rig 


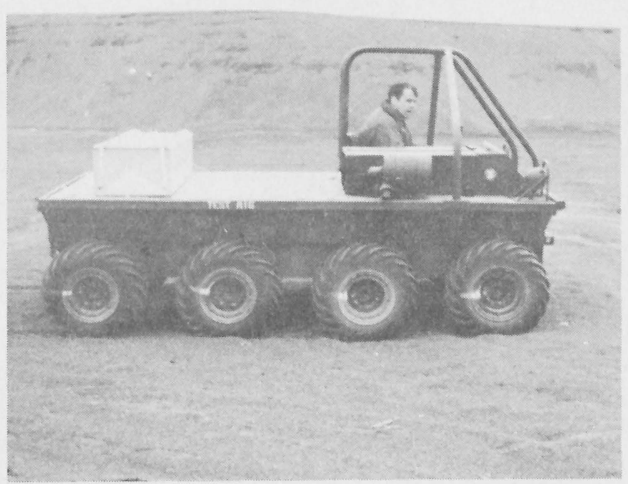

a. Wheeled

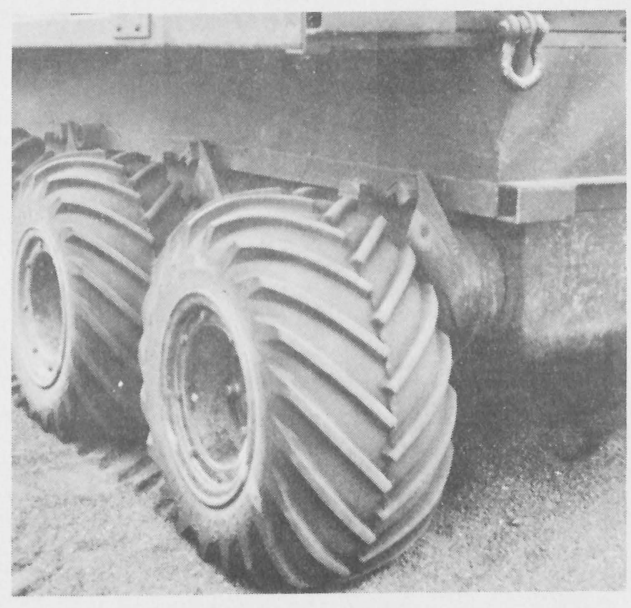

d. Wheeled

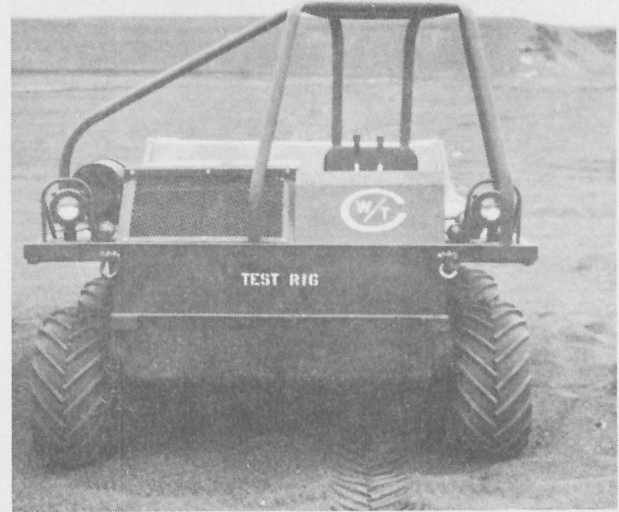

b. Wheeled.

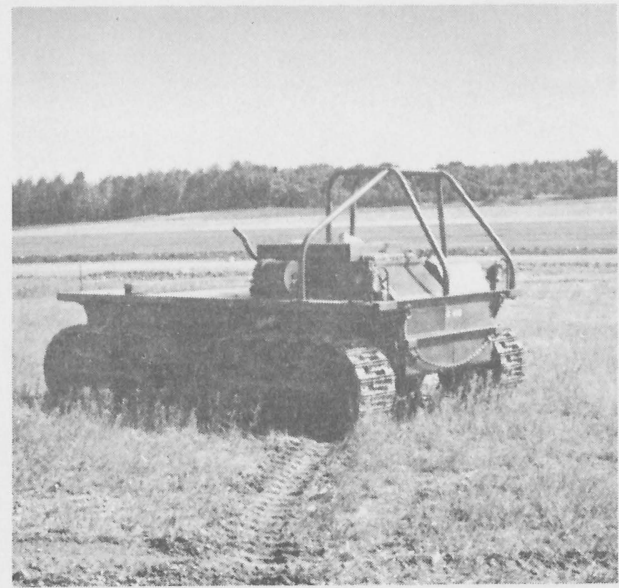

e. Tracked

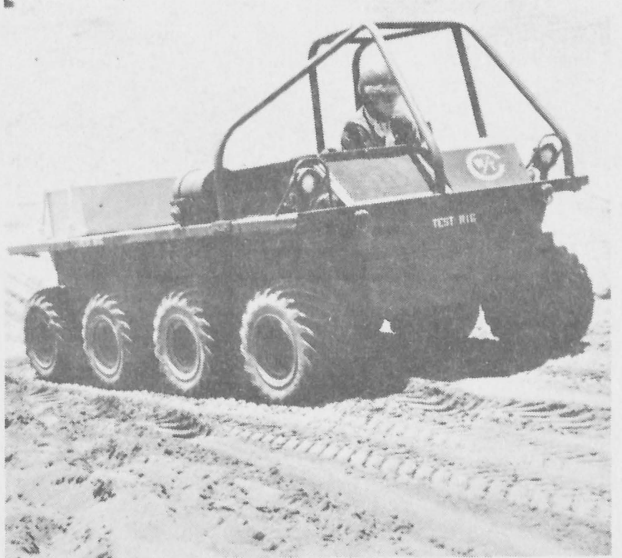

c. Wheeled

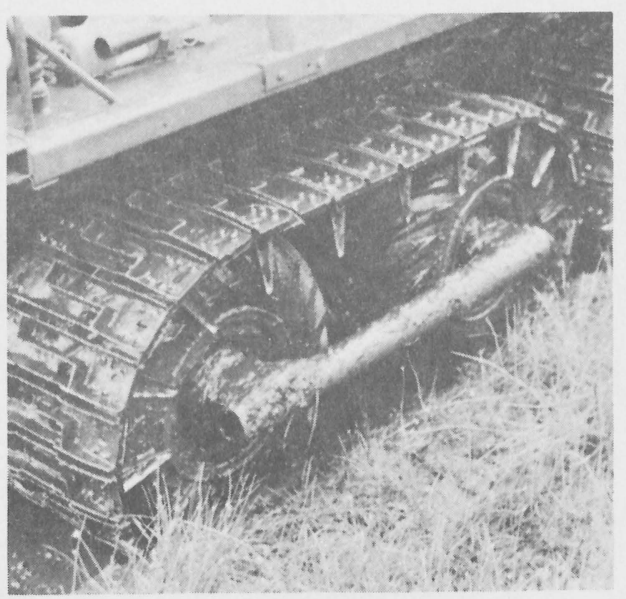

f. Tracked

Fig. 9. Wheel/Track Convertible Test Rig 


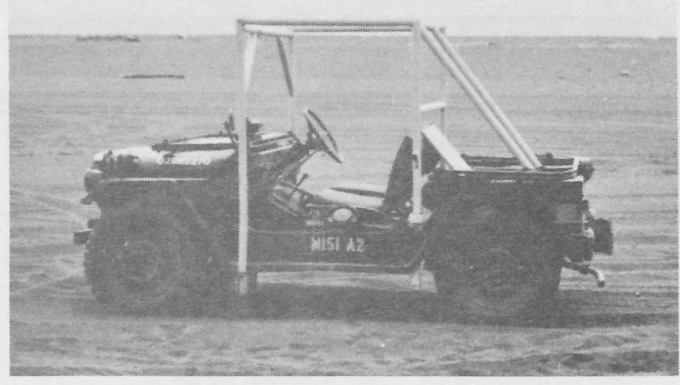

a. M151A2

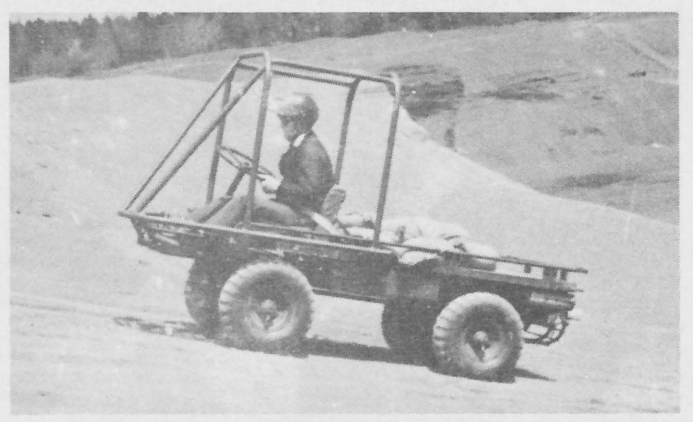

c. $\mathrm{M} 274 \mathrm{~A} 2$

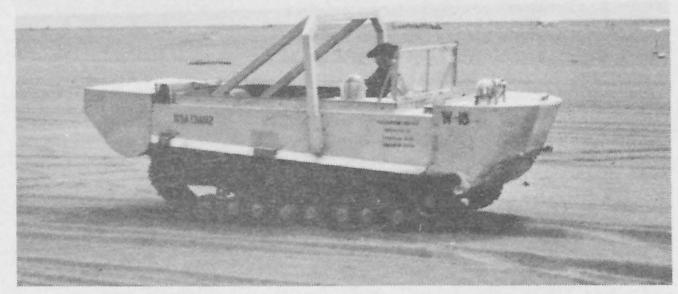

e. M29C

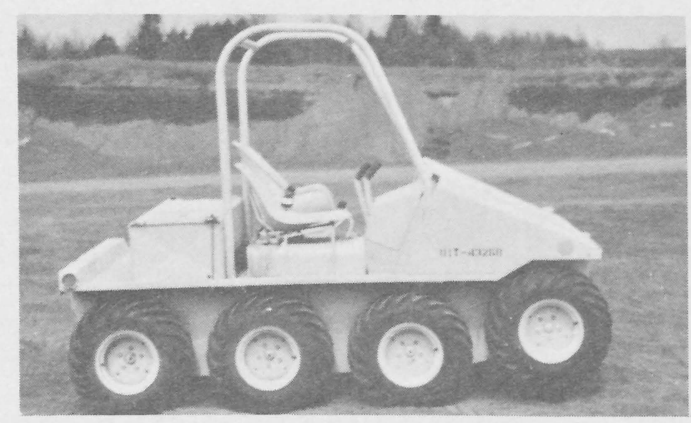

h. Wolverine

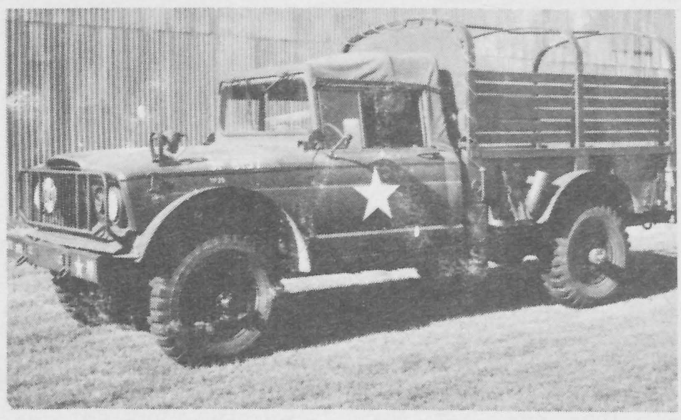

d. M715

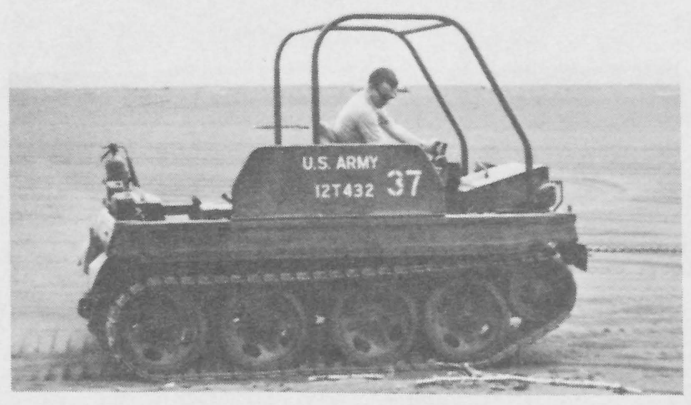

f. MIO4

Fig. 10. Comparison test vehicles 
Tabulated below are the gross test weights, cross-country payloads, and tire pressures (or track widths) of all the vehicles.

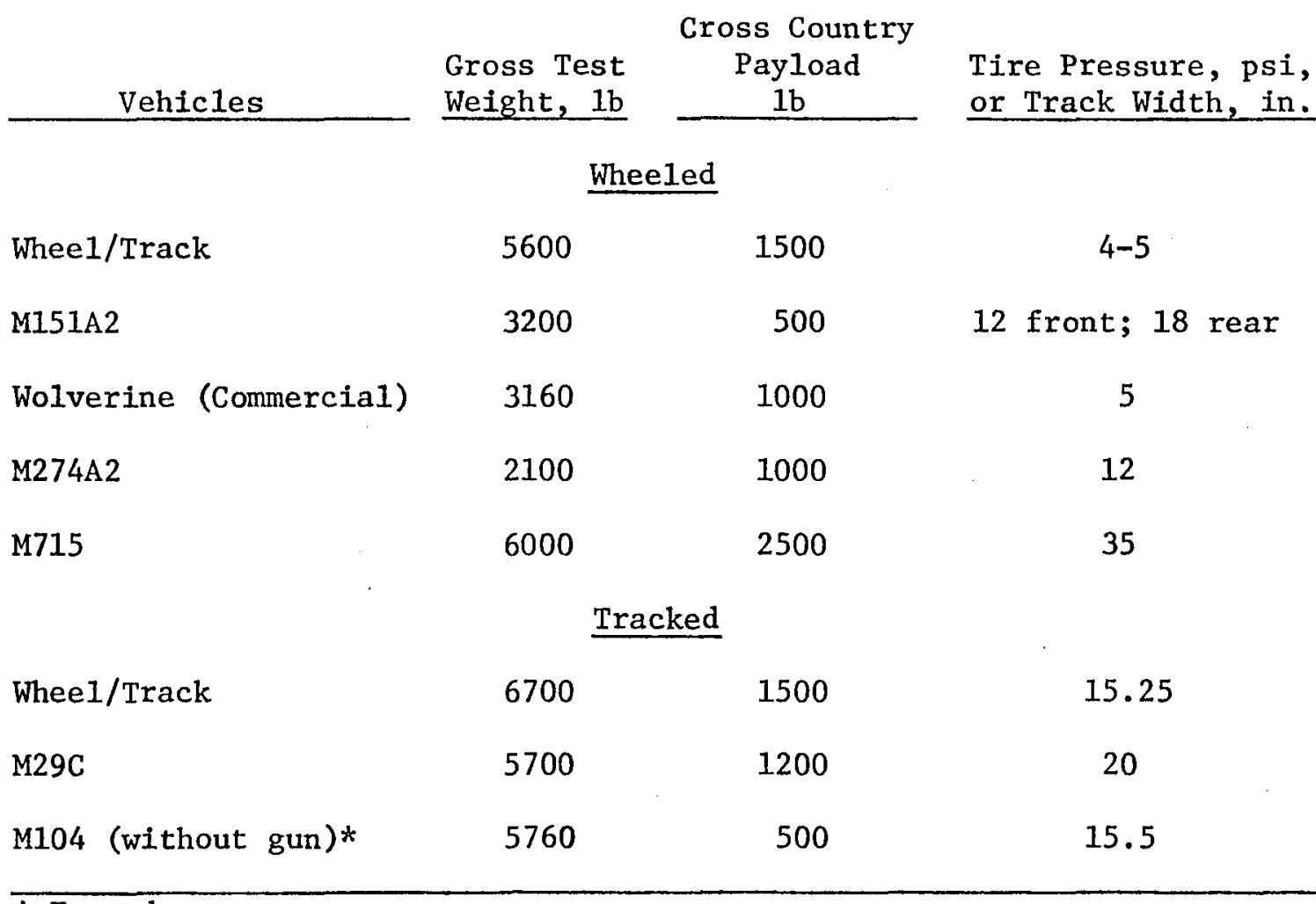

* Tested empty.

Unavailability, generally the result of mechanical breakdowns, precluded testing all vehicles on all test courses or slopes. Two versions of the Wheel/Track Test Rig in the wheeled mode were tested at Gay, Michigan. The original version was powered by a 141-cu-in. jeep engine, but early tests indicated insufficient power and speed output. Therefore, when this version developed mechanical difficulties, a more powerful 289-cuin. engine was installed for the remainder of the test program.

\section{Tests Conducted, Procedures, and Data Collected .}

15. Trail and cross-country tests were conducted to obtain average speeds in a variety of individual trail and terrain (off-road) units, as we11 as average speed over a traverse consisting of a group of 
contiguous trail and terrain units. Tests were also conducted in special-terrain units to acquire data necessary to develop pertinent terrain-vehicle relations or to observe, in special-terrain conditions, behavior at the wheel-track interface. Tests were also run to observe ride and handing characteristics of the Test Rig.

\section{Trail tests}

16. A driver experienced in trail and cross-country testing was selected to drive all test vehicles during all test phases. Each vehicle was driven over the trail course (see fig. 11) at a speed considered by the driver to be the maximum safe speed for that test vehicle based on the limitations imposed by the terrain conditions encountered. The vehicles were timed with a stopwatch through each unit on the trail course. Using these times, speeds were calculated for each vehicle in each trail unit over previously measured distances. All vehicles negotiated the complete 15,000-ft course in clockwise and counterclockwise directions to permit analysis of the directional effects of slopes, microgeometry, vegetation, etc., on vehicle performance. Results of these tests are shown in table 2. The Wheel/Track Test Rig in the tracked mode is not included in this table because mechanical problems forced suspension of tests with the tracked rig before trailcourse testing was conducted.

17. The average speed of each vehicle is shown at the bottom of table 2. In all vehicle tests, especially those with the Whee1/Track Test Rig, an observer-rider accompanied the driver on each test to obtain information on vehicle-driver response to various vehicle-terrain conditions. Information obtained for the main vehicle of interest, the Whee1/Track Test Rig, during these tests is shown in table 3. Figs. 6 and 7 can be used in conjunction with table 2 to analyze fully the performance of the Test Rig on this trail course.

\section{Traverse tests}

18. All the test vehicles were timed with a stopwatch through each of the three terrain units of Traverse 1. Average speeds were calculated for each vehicle in each terrain unit and are shown in table 4. 


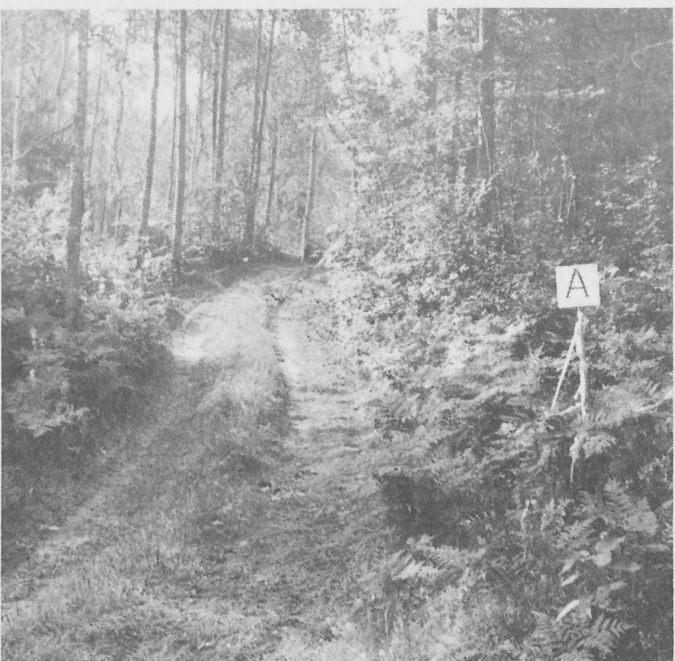

a. Unit A, upslope

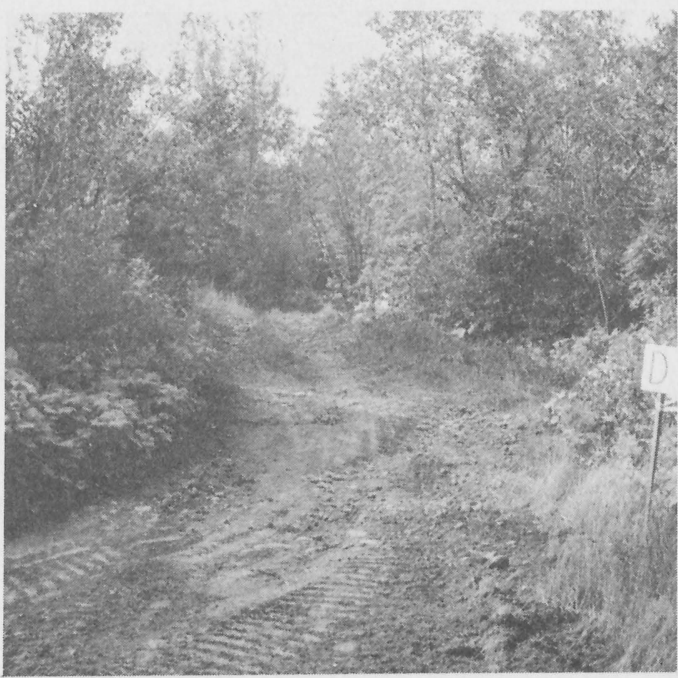

d. Unit D, upslope

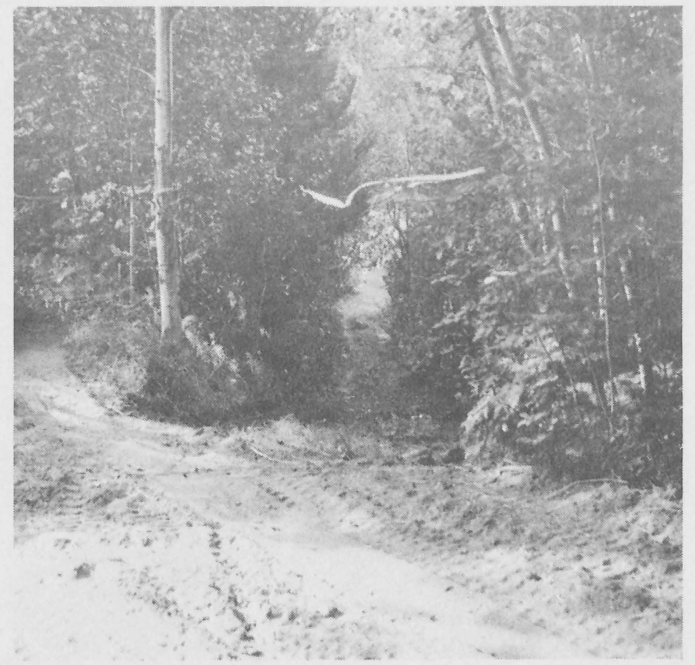

b. Unit B, downslope

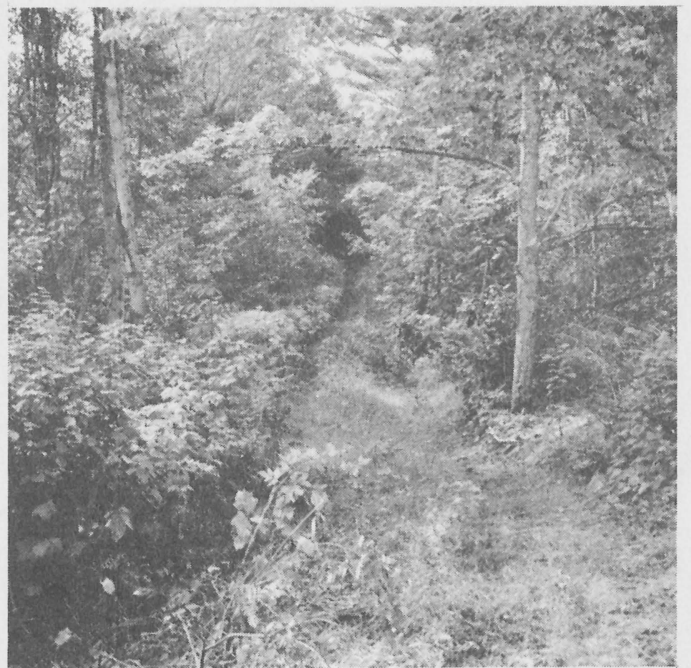

e. Unit E, upslope

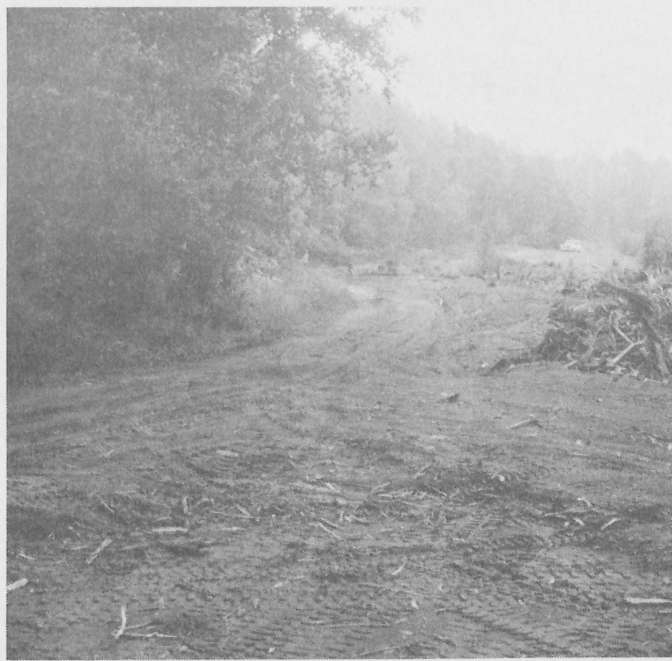

c. Unit C, stamped sand

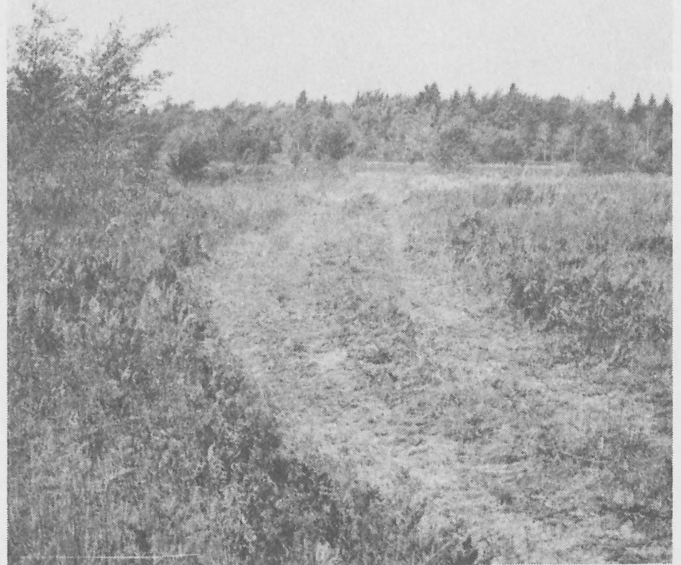

f. Unit F, open, flat, grassy area

Fig. 1l. TACOM Trail Course 2, trail units (1 of 3 sheets) 


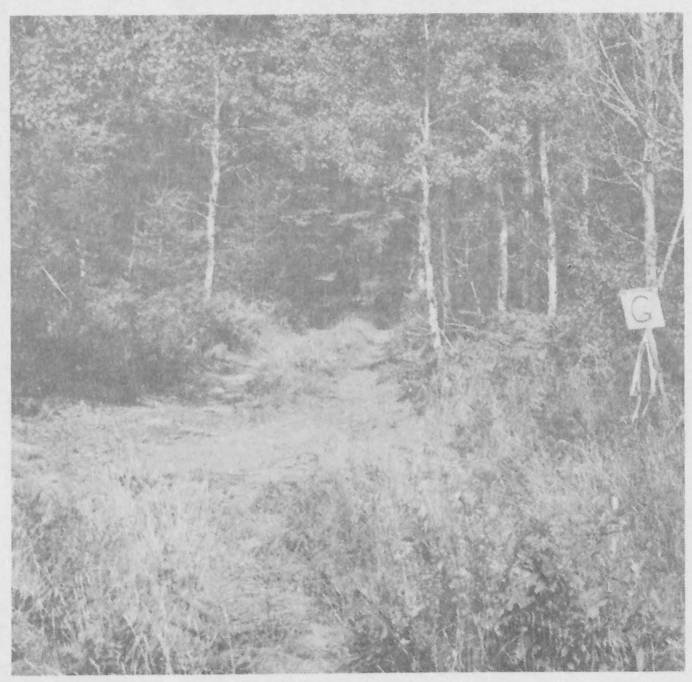

$\underset{f}{n}$

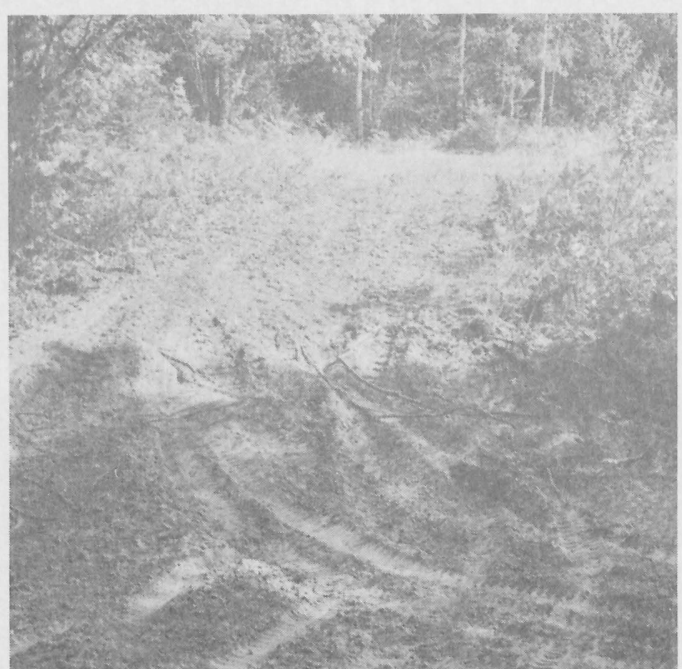

h. Unit $\mathrm{H}$, upslope

g. Unit $G$, narrow trail in heavy woods

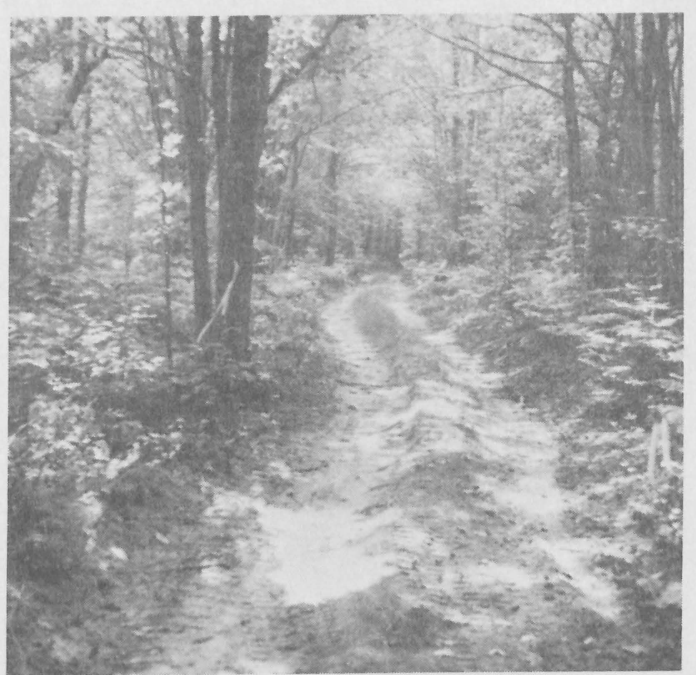

j. Unit J, open trail

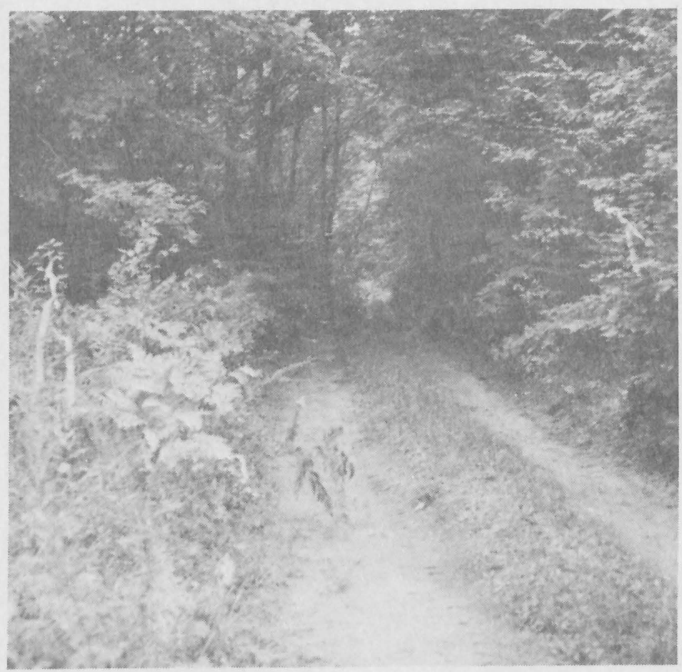

k. Unit $\mathrm{K}$, downslope

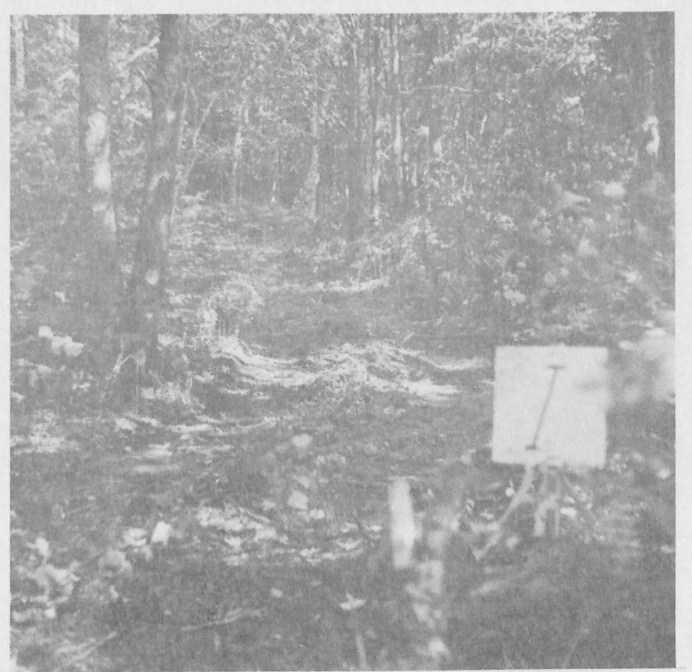

Unit I, surface roughness unit

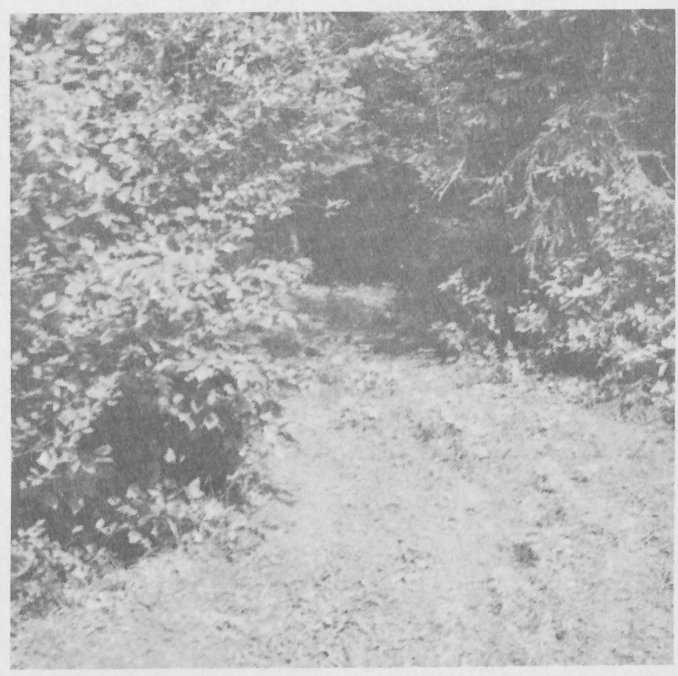

1. Unit $L$, narrow trail in heavy woods

Fig. 11. (2 of 3 sheets) 


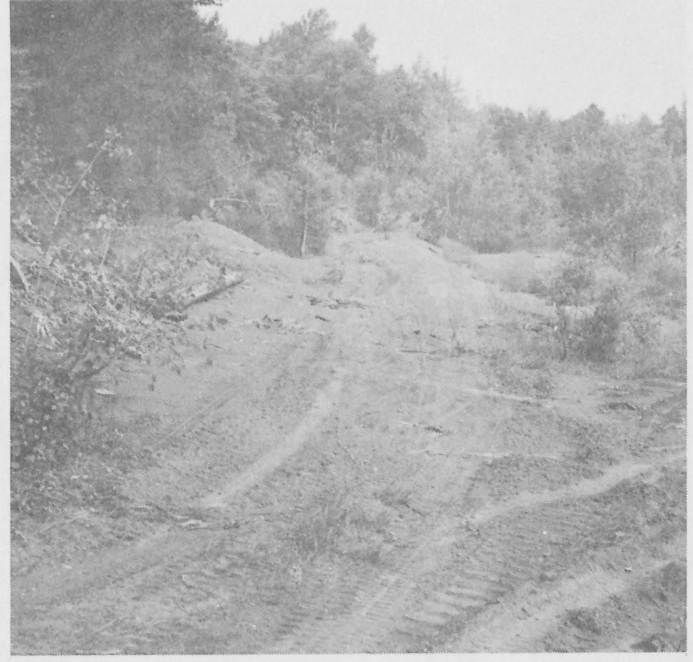

m. Unit $M$, stamped sand

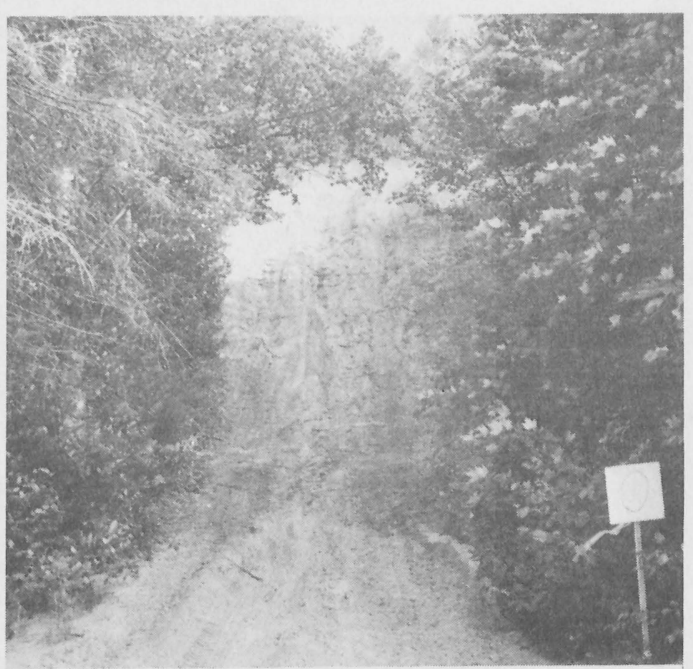

p. Unit $0,32.3 \%$ upslope

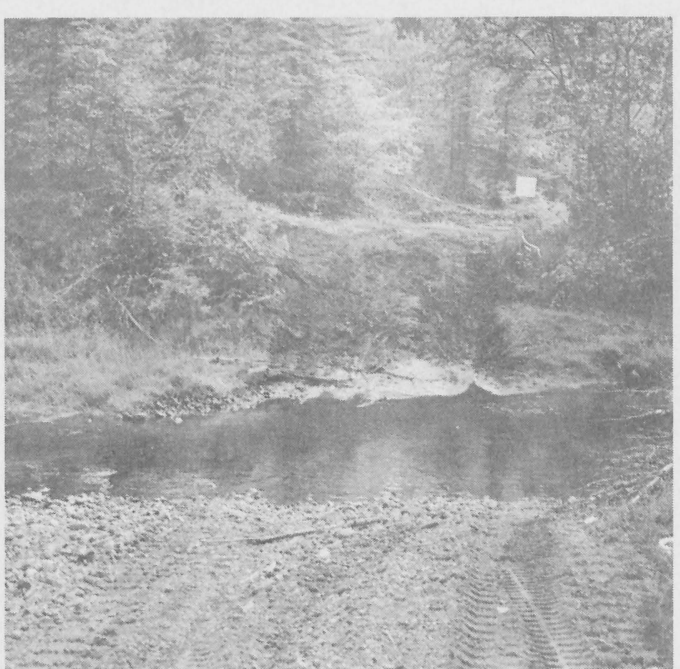

n. Unit $\mathrm{N}$, stream crossing

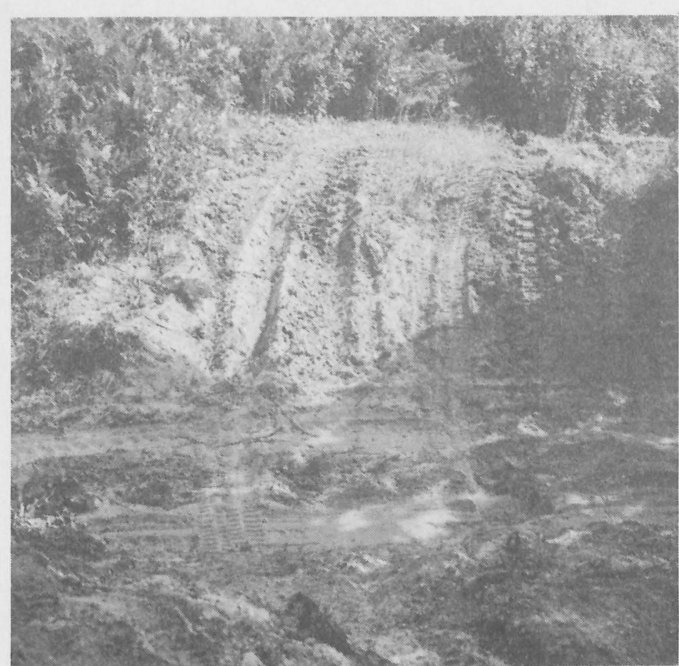

q. Unit $P$, road crossing

Fig. 11. (3 of 3 sheets)

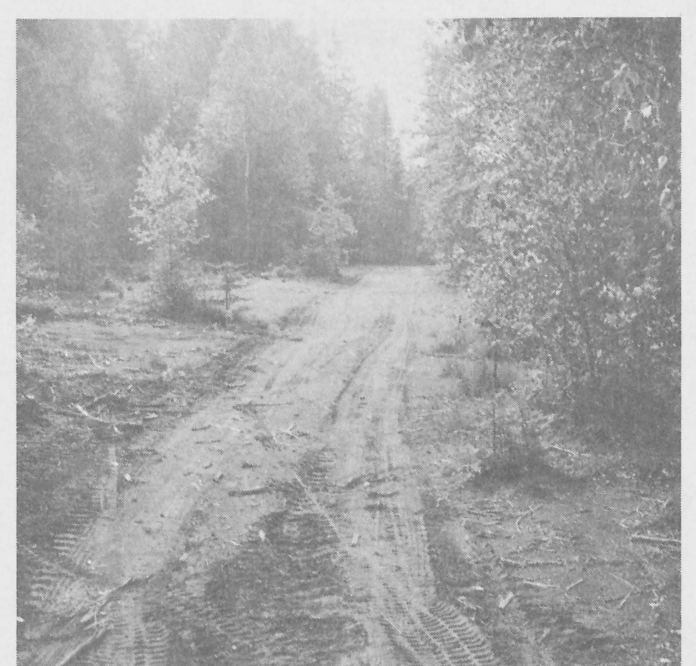

o. Unit NN, stamped sand

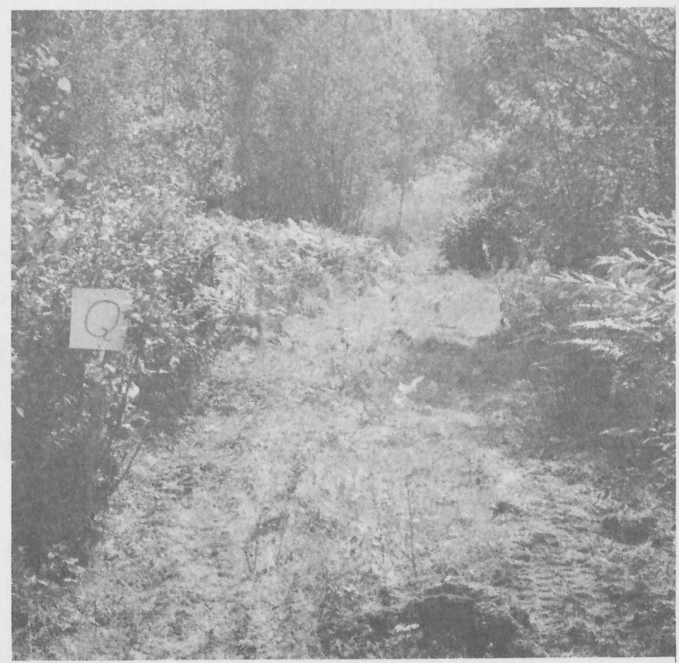

$x$. Unit $Q$, downslope to $A$ 
Pertinent terrain data are described in table 5. Notes and observations of the rider-observer during the traverse tests with the Wheel/Track Test Rig in both wheeled and tracked modes are given in table 6 . Specia1-terrain tests

19. Confined muskeg tests. Trafficability tests were conducted in an organic muskeg (see fig. 12) at Gay, Michigan, with the Test Rig in both wheeled and tracked modes and with one wheeled vehicle (Wolverine) for comparison. Plans called for testing with one tracked vehicle (M29C) also, but trafficability testing with the M29C was deleted from the program because past experience with it indicated that it could make 50 passes with ease in this area. The vehicles were driven forward and backward on a straight 100-ft lane until immobilization occurred, or the required 50 passes were completed. Pertinent soil data and test notes were taken for each test; results are shown in table 7 .

20. Several general maneuvering and handling tests were conducted in the muskeg site with the Wheel/Track Test Rig in both modes, the Wolverine, and the M29C to obtain information for comparing performance of the three vehicles. In these tests the driver maneuvered each vehicle through a lightly forested muskeg area to determine vehicle response to the sharp turns required to maneuver around trees and maintain a constant speed in the organic terrain. In the more open area used for the trafficability tests, the driver completed the tightest turning circle possible with each vehicle as determined by the terrain conditions. Results of these maneuvers will be discussed later in this report. (see paragraph 47).

21. Stamped-sand tests. The stamped-sand site (see fig. 12) at Gay, Michigan, was divided into two general test areas by texture and grain size, fine stamped rock and coarse stamped rock. Measurements of maximum speed, maximum sustained drawbar pul1, and average towed motion resistance were obtained for each vehicle tested in the finestamped-sand area $(C I=110)$. Slope-negotiability and speed-on-slope tests were conducted in the coarse-tailings area. 


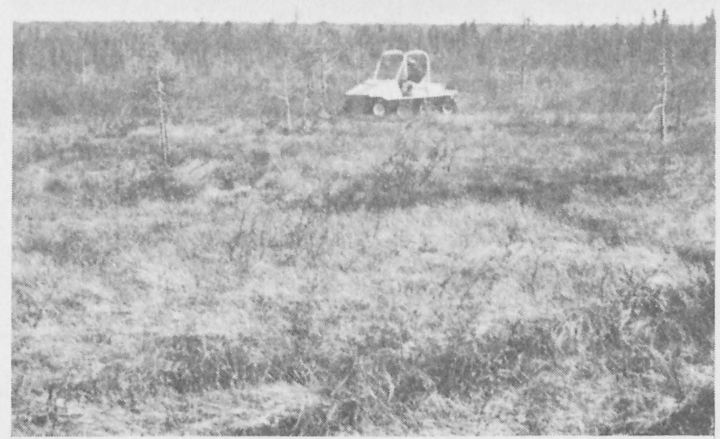

a. Areal view, muskeg area

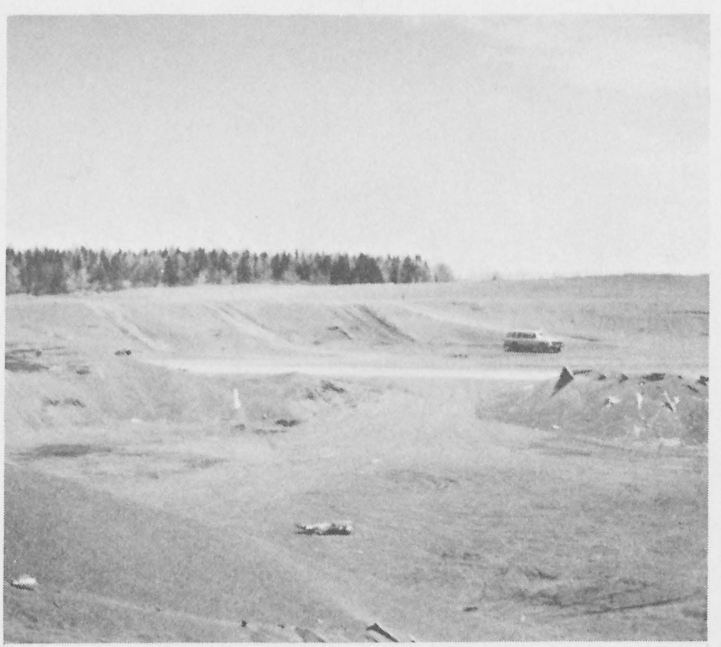

d. Areal view, stamped sand slopes

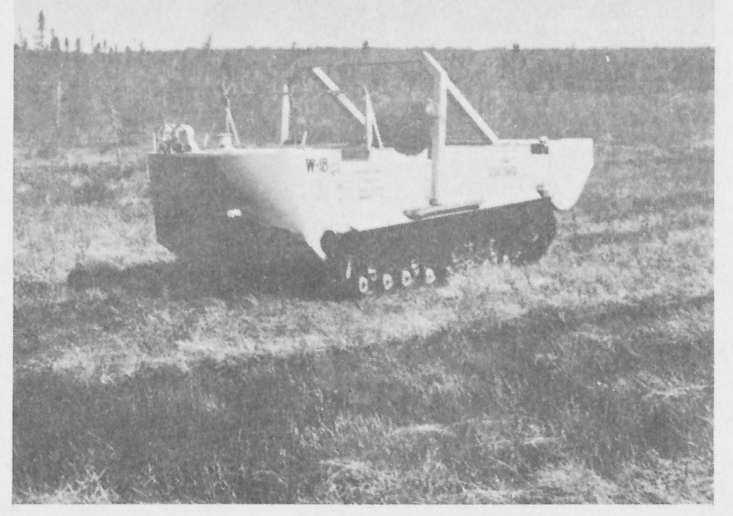

b. General view muskeg area

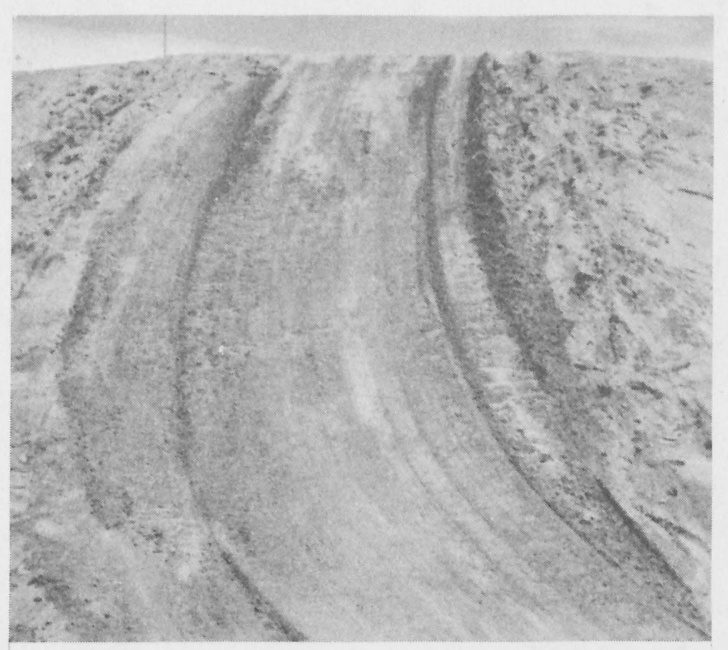

e. General view, stamped sand slope

Fig. 12. Special-terrain tests
7 6row

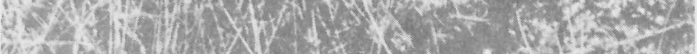
(5) 1 )

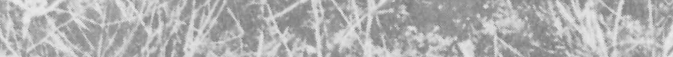

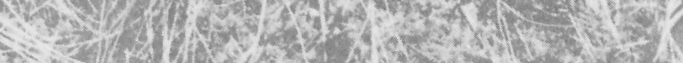

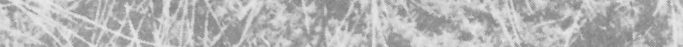

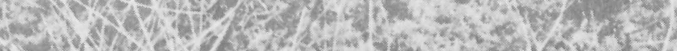

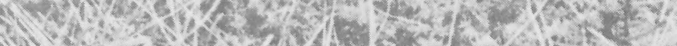

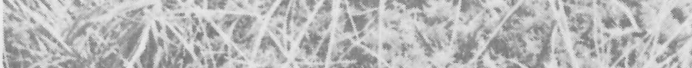

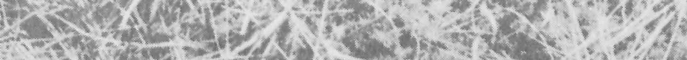

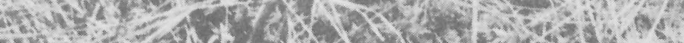

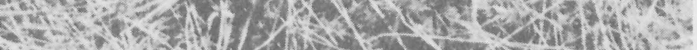

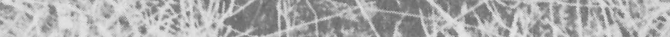

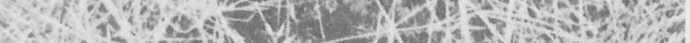
Q a 2 -

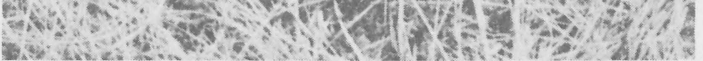

\section{c. Closeup, muskeg area}

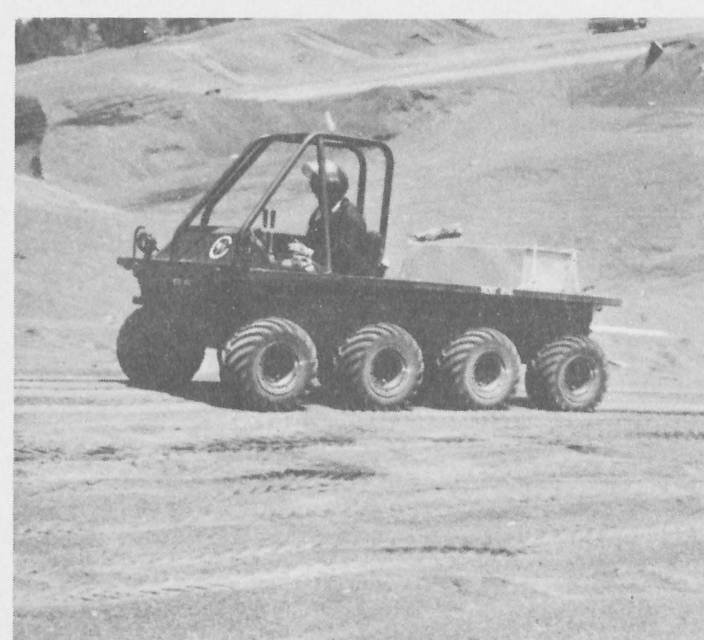

f. Wheeled vehicle slope 
22. In the fine stamped-sand area, a 200-ft-long timing lane was marked off in a relatively open area with ample acceleration distance at each end for maximum speed tests with the vehicles. The test lane ran north to south parallel to the Lake Superior shoreline. A 15-mph wind from the south and a southerly downslope of 1 percent required tests in both directions through the timing lane to obtain average speeds uninfluenced by these factors. Test results are shown in table 8 .

23. Drawbar-pull tests were conducted parallel to the speed test lane. The maximum sustained drawbar pull developed by each vehicle in low gear was measured with a hydraulic load cell. The load applied to the vehicle was gradually increased until the vehicle developed a maximum sustained drawbar pull as indicated by the load ce11. This sustained pull was usually developed at high track or wheel slip (near 100 percent). Upon completion of drawbar-pull tests, the test vehicles were towed at $2 \mathrm{mph}$, and the average motion resistance of the vehicle in the stamped sand was obtained with a hydraulic load cell. Results of these tests also are shown in table 8.

24. The coarse-stamped-sand area was used for slope-negotiability and speed-on-slope tests. Preliminary testing indicated slopes in excess of 15 percent would be necessary to seriously influence vehicle performance. Therefore, tests were conducted on slopes ranging from 15.3 to 58 percent. The slopes were smoothed before each vehicle test by dragging two large timbers behind a support vehicle. Pertinent slope and soils data were collected as shown in the tabulation below. 


\begin{tabular}{|c|c|c|c|}
\hline Slope No. & Slope, \% & Slope Length, ft & $\begin{array}{l}\text { Cone Index } \\
0 \text { - to 6-in. }\end{array}$ \\
\hline 1 & 15.3 & 90 & 208 \\
\hline 2 & 23.8 & 50 & 90 \\
\hline 3 & 27.6 & 85 & 202 \\
\hline 4 & 33.6 & 35 & 91 \\
\hline 5 & 38.8 & 35 & 54 \\
\hline 6 & 46.0 & 30 & 44 \\
\hline 7 & 54.0 & 30 & 71 \\
\hline 8 & 58.0 & 30 & 59 \\
\hline
\end{tabular}

Each vehicle was placed in a starting position on level ground with the front of the vehicle at the toe of the slope. The vehicle was accelerated upslope through a timing zone to obtain data on the effects of slope on vehicle speed. Vehicle performance in terms of speed was obtained with a stopwatch to determine the speed on each slope. Slopes of increasing magnitude were used for each vehicle until an immobilization occurred. In al1 tests several runs were conducted with each vehicle in a range of gear combinations to obtain an optimum combination for maximum speed-on-slope. The best speed on each slope (unless noted) is included, together with pertinent test notes, in table 9 . 
25. Two general areas were selected for special-terrain tests at Vicksburg: an area 16 miles north of Vicksburg near an o1d Mississippi River bend, now known as Albemarle Lake, and the reservation area of the WES. Three test sites were selected near Albemarle Lake (fig. 13): a soft alluvial buckshot clay area, grassy clay slopes, and a firm buckshot clay area nearby, known as Parker's Farm. Two sites were used at the WES: grassy silt slopes and a facility containing prepared test pits of clay (CH) and sand (SP) (USCS classification).

\section{Description of Test Sites}

\section{Albemarle Lake Area}

26. Wooded clay site. Albemarle Lake is a small oxbow located on the Louisiana-Mississippi border northwest of Vicksburg, Mississippi. The water level in the lake rises and falls with that of the Mississippi River, which feeds the lake. At the time of this test program, the river stage was low, and a wide expanse of wooded lakeshore was exposed and accessible. A gradual decrease in soil moisture content with increase in distance from the water's edge permitted testing on a range of soil strengths in a small area. Likewise, the water table varied from the surface near the water's edge to a few inches below the surface near the high bank. Willow trees with trunks ranging in diameter from 8 to $16 \mathrm{in.}$ grow at the test site on a 10- to 12-ft average spacing.

27. Clay slopes. Two grassy clay slopes on the high bank above the wooded area were used for testing. One was a natural slope and the other was the end of a spur levee constructed at a time when the main stream of the Mississippi River passed near the test area. Both slopes were completely covered with Bermuda grass 4 to 6 in. high. 


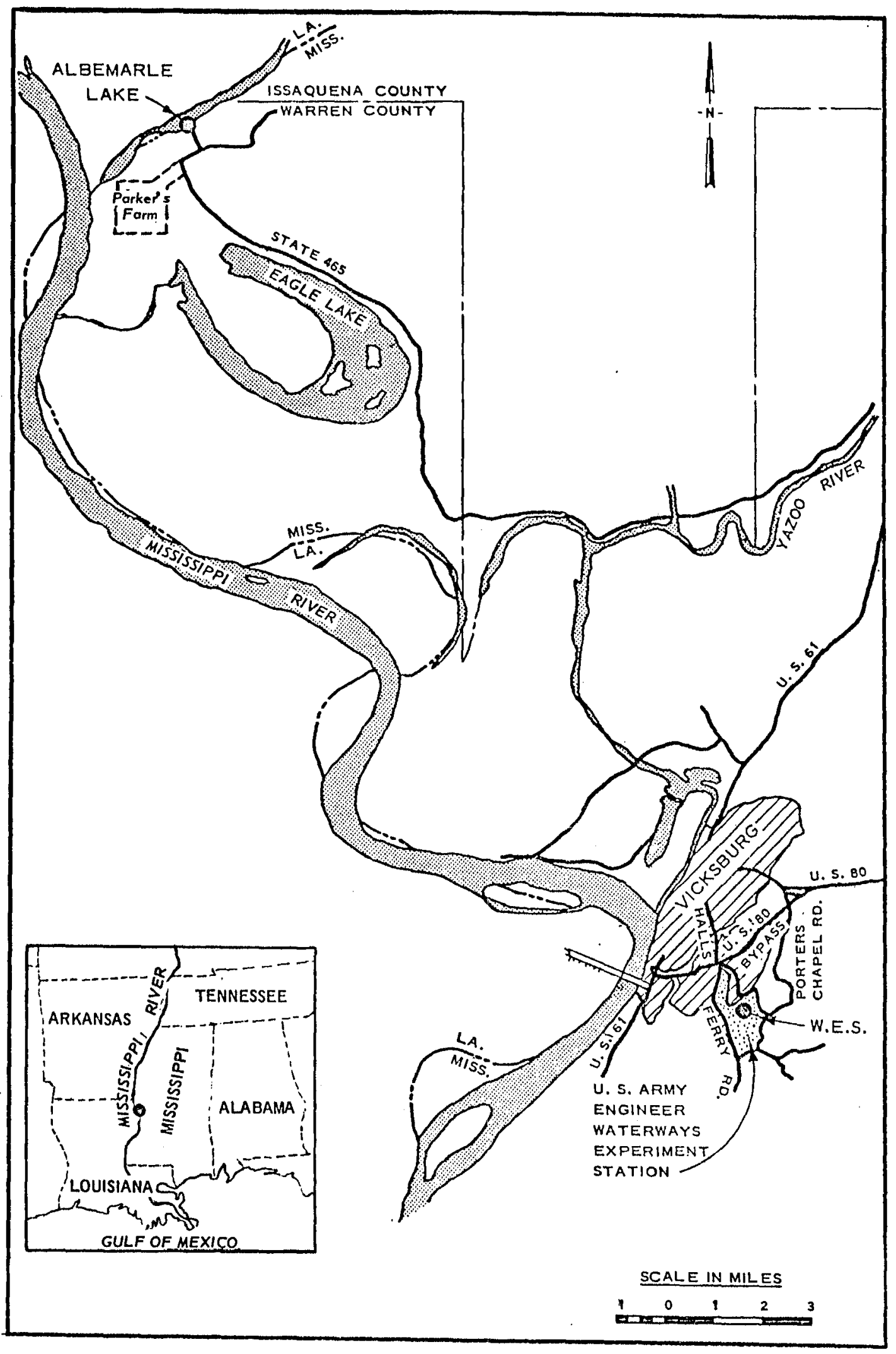

Fig. 13. Location of test areas, Vicksburg, Mississippi 
28. Parker's Farm. Three firm buckshot clay courses completely covered with 6-in.-high Bermuda grass were selected at Parker's Farm (fig. 13) for determination of vehicle dynamic responses at various speeds over three degrees of surface roughness. The courses were selected based on availability and, therefore, were not variable enough to obtain a complete set of surface roughness-speed data for both wheeled and tracked versions of the Wheel/Track Test Rig. WES reservation

29. Grassy silt slopes. Three steep silt slopes on the WES grounds were used for longitudinal speed-on-slope tests and side-slope tests (operation across the slope face) with the Test Rig. The slope embankments were created during construction of a roadbed bridging a deep ravine. They are completely covered with Bermuda grass, which had been mowed before the tests to about 2 in. high.

30. Laboratory clay and sand pits. Two prepared buckshot clay (CH) pits and one prepared sand (SP) pit were used for drawbar-pul1 and towed-motion-resistance tests. The clay pits were prepared to achieve two soil strengths, one approximately half the strength of the other. The sand pit was densified, pure, dry mortar sand.

\section{Test Vehicles}

31. Of the vehicles tested at Houghton, only the Wolverine and the Whee1/Track Test Rig were tested at Vicksburg. An M15I at the same cross-country payload replaced the M151A2 tested at Houghton. The Test Rig was tested as an $8 \times 8$ vehicle in both wheeled and tracked modes, and as an $8 \times 4$ in the tracked mode as time permitted.

\section{Tests Conducted, Procedures, and Data Collected}

32. Time restrictions placed on the test program after the Houghton tests resulted in minimum testing at Vicksburg, with emphasis on testing the Wheel/Track Test Rig in soft soil and in the laboratory. 
Maneuvering and handling tests, therefore, were conducted in soft soil with the Test Rig to observe wheel-track interaction at their interface, as well as general performance while the vehicle was operating in soft, adhesive buckshot clay, which coated the entire vehicle running gear. Several tests were also conducted on grassy clay and silt slopes to compare Test Rig speeds with those of the other vehicles and to gain insight into vehicle "go-no go" slope-climbing ability. Drawbar-pu1l and towed-motion-resistance tests were conducted with the Test Rig on laboratory-prepared clay $(\mathrm{CH})$ and sand (SP). No Wolverine drawbar-pul1 tests were conducted; results of previously conducted tests with the M151 and the M29C were used for comparison purposes. Preliminary tests were also conducted for determination of vehicle performance during surface roughness tests.

\section{Albemarle Lake tests}

33. Wooded, clay sites. General maneuvering and handling tests were conducted with the Test Rig in both wheeled and tracked modes in the wooded, alluvial soft clay area at Albemarle Lake. Areas were selected in the willows with sufficient spacing between trees to permit mounting of a high-speed camera on the vehicle to photograph mud accumulation on the running gear and possible slip at the wheel/track interface. The mounting bracket and camera added $3 \mathrm{ft}$ to the required lateral clearance for vehicle passage. Consequently, areas were selected that afforded sufficient lateral clearance for vehicle and camera passage. Areas were selected to obtain a range of soil strengths, beginning at the water's edge and moving landward. Three areas were used based on the 0 - to 6-in. RCI of each area: 11 RCI at the water's edge, $14 \mathrm{RCI}$ at $75 \mathrm{ft}$ landward of the water's edge, and 24 RCI near the high bank some 200-250 ft from the water's edge. Soil data for the 0- to 6-in. soil layer are shown below. 


\begin{tabular}{|c|c|c|c|c|c|}
\hline Area & $\underline{\mathrm{CI}}$ & $\mathrm{RI}$ & $\underline{\mathrm{RCI}}$ & Moisture Content, \% & Dry Density, $1 \mathrm{~b} / \mathrm{ft}^{3}$ \\
\hline 1 & 16 & 0.70 & 11 & 148.1 & 32.7 \\
\hline 2 & 20 & 0.70 & 14 & 125.4 & 36.6 \\
\hline 3 & 38 & 0.64 & 24 & 105.2 & 35.2 \\
\hline
\end{tabular}

In each test area the driver switched on the high speed camera prior to the test and began maneuvering through the designated test lane. Maneuvering around the willows continued until the supply of film was exhausted in the camera (about 1-1/2 minutes). Appropriate test notes including driver comments on vehicle performance, estimates of mud buildup, and observations of handling characteristics were recorded for tests in each area.

34. Clay slopes. Two grassy clay slopes as described below were selected for speed-on-slope and side-slope tests.

\begin{tabular}{cccc} 
Slope No. & Slope, $\%$ & Slope Length, ft & Cone Index \\
\hline 1 & 25 & 75 & 149 \\
2 (levee) & 35 & 75 & 417
\end{tabular}

In the speed tests each vehicle was accelerated upslope from a starting position at the toe of the slope through a 75-ft timing lane in the optimum gear/gear range configuration for maximum speed upslope. Speeds were calculated with a stopwatch and are shown in table 10 . As indicated, the vehicles slipped slightly at the toe of slope 1, which was a high bank rising from the Albemarle Lake shore area and was slightly soft. Note that the tracked test rig was not tested on these slopes. The drive shafts of the Test Rig with tracks installed are more susceptible to shear on firm areas, especially in maneuvering, because of the increased traction obtained with the tracks. The lowpressure Terra-tires, which deflect substantially during maneuvering, remove some of the rigidity of the drive system that must remain on a more restrained setup, such as the tracked version. Therefore, no speed tests were attempted with the tracked version. 
35. Upon completion of longitudinal slope tests, the tracked Test Rig was operated across the face of the slopes to observe the effect of side loadings on the vehicle running gear. Photographic coverage of vehicle operation at angles to the face of the slope was used, along with visual observation of vehicle performance, to analyze vehicle running gear performance under stresses induced by side loadings. At no time, however, did slip occur at the wheel-track interface.

36. Parker's Farm. The wheeled and tracked versions of the Wheel/Track Test Rig were driven at various speeds over three dynamics courses with surface roughness levels of $0.67,1.44$, and 1.49 in. (rms elevations), respectively. Only two days were allotted for these tests. Limited data obtained from instrumentation of the vehicle for dynamic responses were used to construct preliminary curves of surface roughness at the 6-watt level versus vehicle speed, as shown in figs. 14-16. WES tests

37. Slopes. Three steep, grassy silt slopes, as described below, were used for slope tests on the WES reservation.

\begin{tabular}{cccc} 
Slope No. & Slope, $\%$ & Slope Length, ft & Cone Index \\
\hline 3 & 40.3 & 35 & 451 \\
4 & 44.2 & 35 & 368 \\
5 & 53.5 & 50 & 368
\end{tabular}

Speeds-on-slopes were determined as described in paragraph 34, and are shown in table 10. Slopes of more than 53.5 pexcent were not available to conclusively determine the "go-no go" point for the vehicles on grassy silt.

38. Laboratory. Five drawbar-pul1 and towed-motion-resistance tests were conducted in the laboratory at WES with the Whee1/Track Test Rig in wheeled and tracked modes in $8 \times 8$ and $8 \times 4$ configurations. The wheeled and tracked versions were tested in an a11-whee1-drive $8 \times 8$ configuration. The drive gear to the first and third road arms on each side of the tracked Test Rig was removed, and tests were conducted 


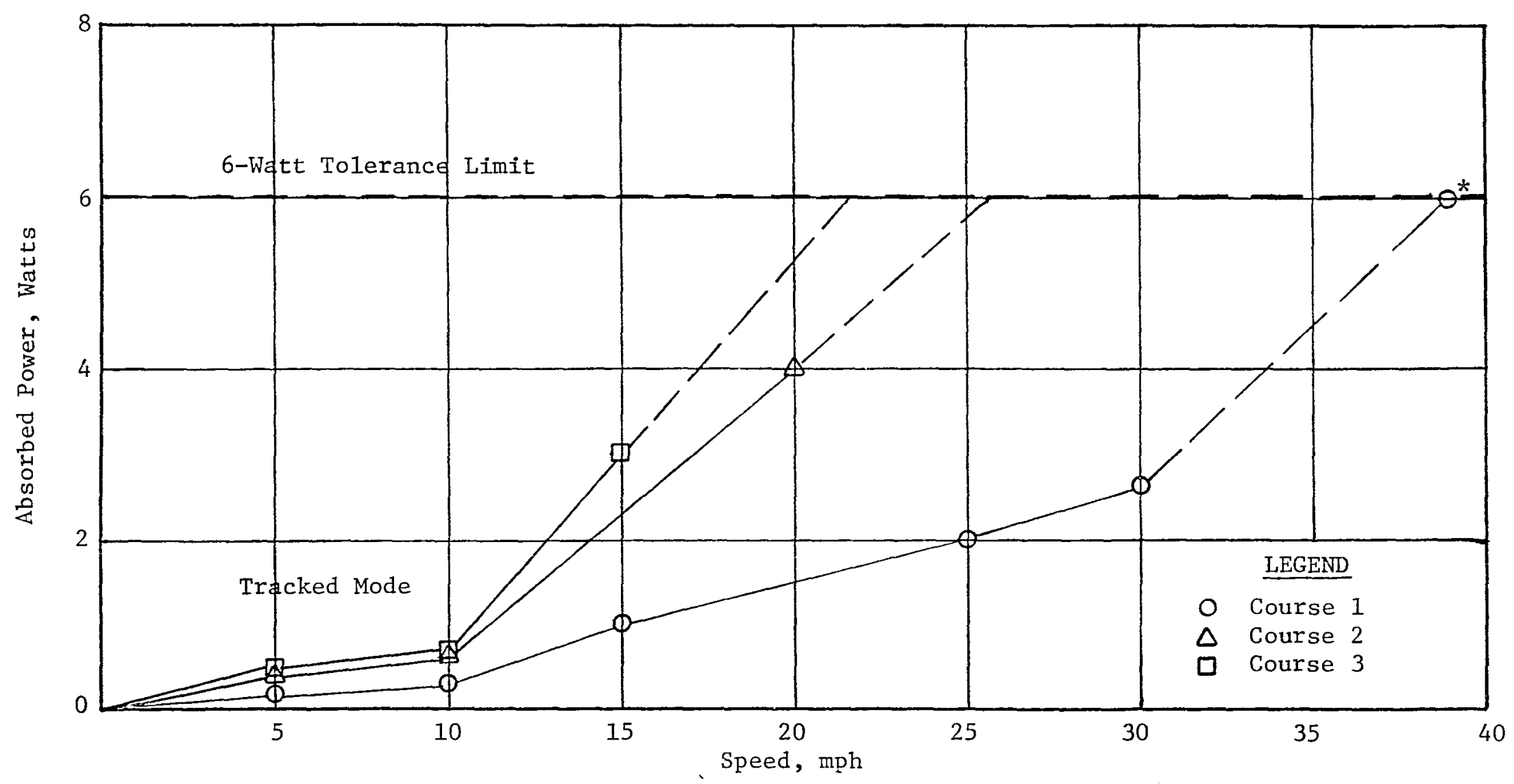

* Low frequency wavelengths becoming significant at $30 \mathrm{mph}$; would most likely reach 6 watts at some slightly higher speed. Estimate could not exceed $40 \mathrm{mph}$. Tests stopped at $30 \mathrm{mph}$ to preclude possible structural damage.

Fig. 14. Absorbed power versus speed, Wheel/Track Convertible, Parker's Farm, Vicksburg, Mississippi, preliminary test results 


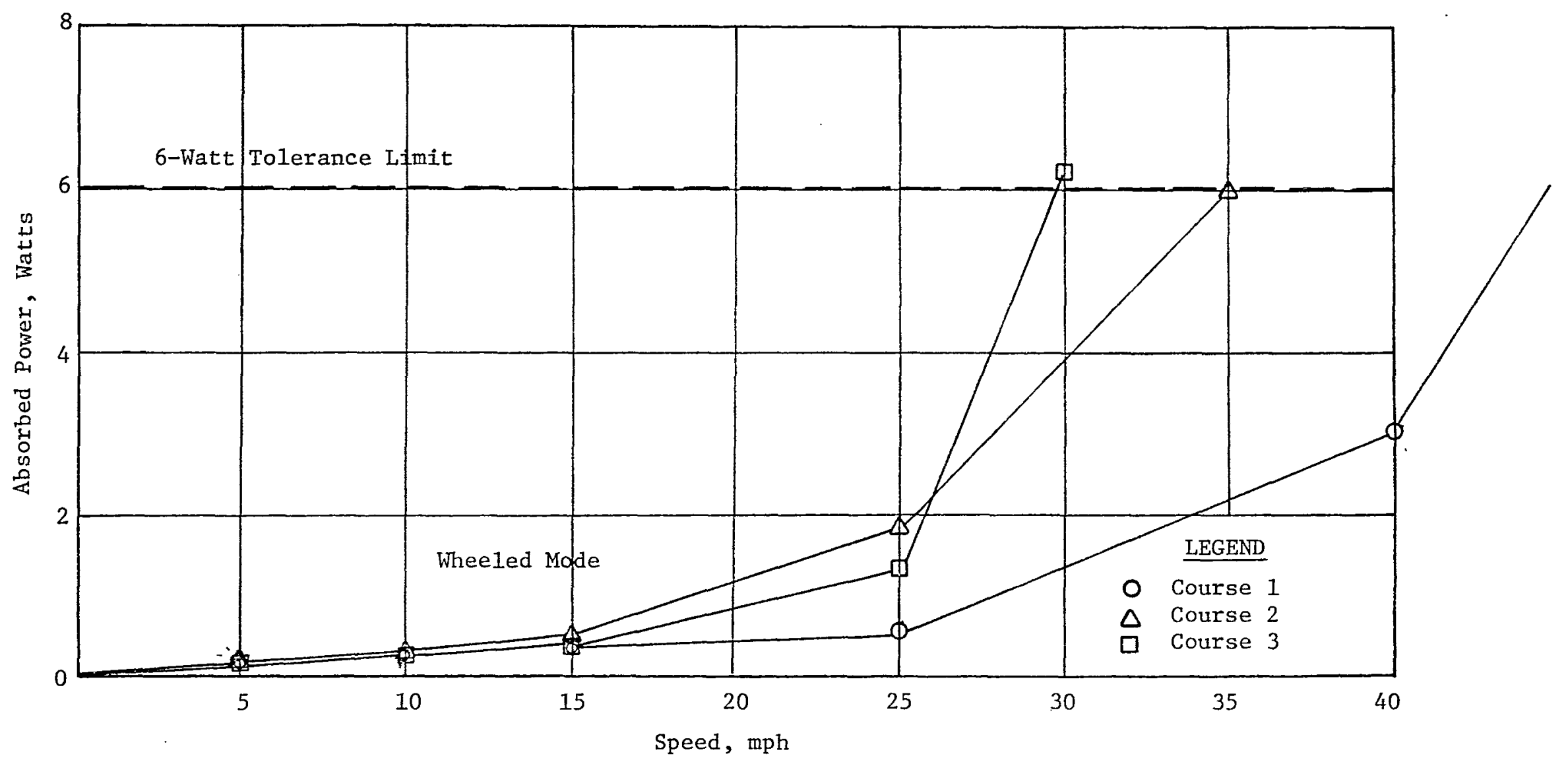

Fig. 15. Absorbed power versus speed, Wheel/Track Convertible, Parker's Farm, Vicksburg, Mississippi, preliminary test results 


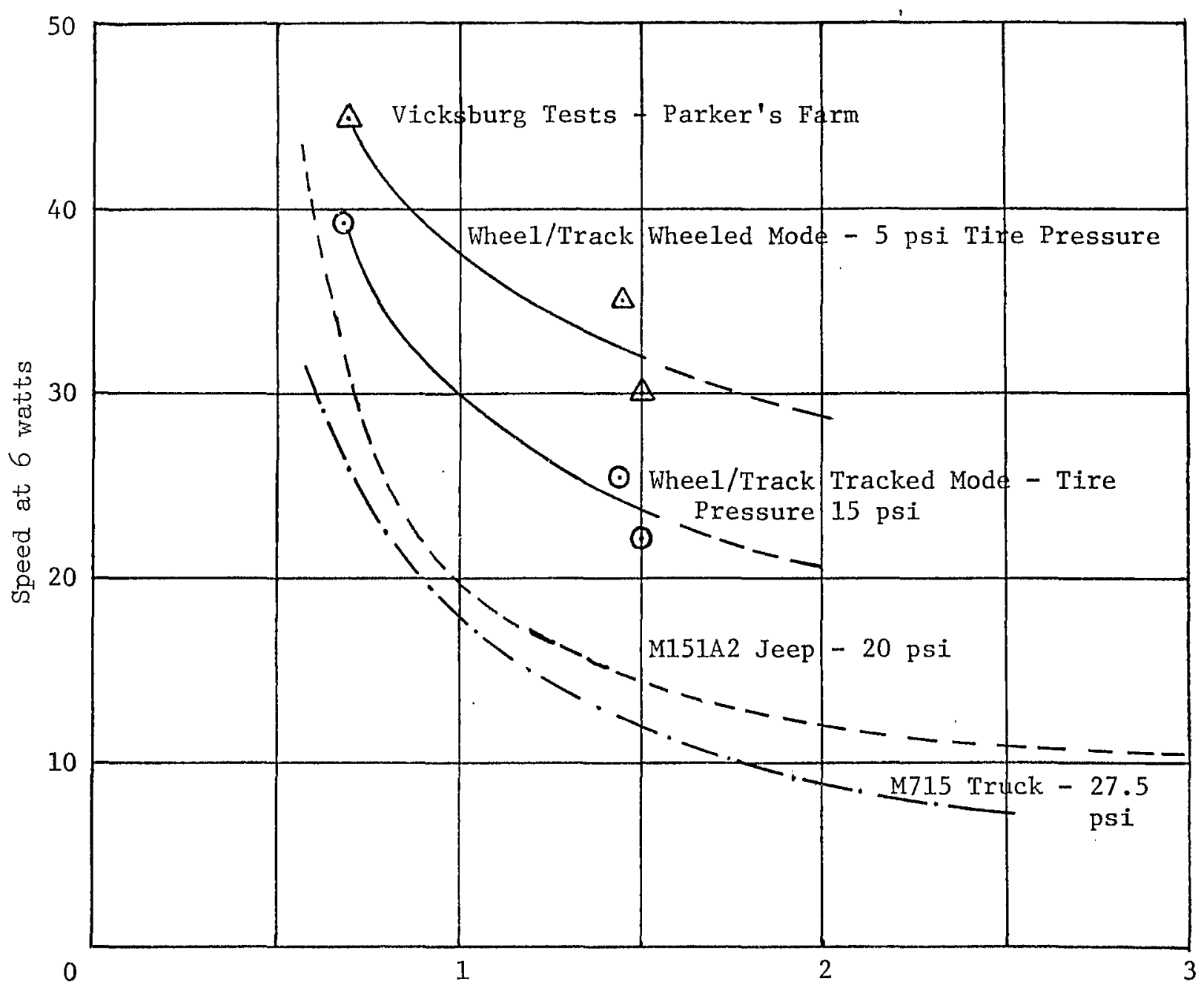

Surface Roughness, rms, in.

NOTE: These data represent preliminary tests with the Wheel/Track Convertible. The relation for the M151A2 Jeep represents composite results of four test programs. The relation for the M715 truck was determined from data obtained in another project.

Fig. 16. Comparison of ride quality of selected vehicles 
in the $8 \times 4$ configuration (second and fourth wheels pulling) for observation of wheel-track interface action at the rear pulling wheels. Three tests in prepared clay $(\mathrm{CH})$ and two in fine sand (SP) were conducted in the wheeled and tracked modes. Soil data for these tests are as follows:

$\begin{array}{ccccc}\text { Whee1/Track Test Rig } & \text { Test Pit } & \begin{array}{c}\text { RCI or CI } \\ \text { 0-to 6-in. }\end{array} & \begin{array}{c}\text { Moisture } \\ \text { Content, } \% \\ \text { 0-to 6-in. }\end{array} & \begin{array}{c}\text { Dry Density, } \\ \text { Ib/ft }\end{array} \\ \text { Wheeled } 8 \times 8 & \text { Clay (CH) } & 66 & 39.50 & 80.3 \\ \text { Tracked } 8 \times 8 & \text { Clay (CH) } & 36 & 40.00 & 77.7 \\ \text { Tracked } 8 \times 4 & \text { Clay (CH) } & 36 & 40.00 & 77.7 \\ \text { Tracked } 8 \times 8 & \text { Sand (SP) } & 15 & 0.05 & 95.5 \\ \text { Tracked } 8 \times 4 & \text { Sand (SP) } & 15 & 0.05 & 95.5\end{array}$

39. During drawbar-pull testing the drive axle shafts in the cross-drive unit sheared in the first test. New shafts were not commercially available at test time. Therefore, to complete testing a "shear-pin" system was used to prevent shear of the shafts, which were welded back together. Bolts were installed between the cross-drive and the rear driving wheels, calculated to shear at less than $5000 \mathrm{lb}$, the approximate shearing strength of the welded shafts. This system allowed completion of the tests, although maximum-drawbar-pul1 values were not obtained for all test conditions, as shown in table 11. 


\section{PART IV: ANALYSIS OF DATA}

\section{Tests at Houghton, Michigan}

\section{Trail tests}

40. Results of trail tests with each vehicle run in clockwise $(A-Q)$ and counterclockwise $(Q-A)$ directions around the closed-loop course are shown in table 2. Speeds obtained in each of the 18 terrain units are included for the various vehicles tested. Analysis of trail unit speeds for $A-Q$ and $Q-A$ directions for each vehicle indicate variations in speeds as affected by the trail factor combinations shown in table 1. For example, Trail Unit $A$ is a relatively open area with a 6.9 percent slope upward in the $A-Q$ direction and downward in the Q-A direction, with minor influences from vegetation and surface roughness. As indicated in table 2, all test vehicles were able to negotiate Trail Unit $A$ in the downslope direction (Q-A) faster than in the upslope direction $(A-Q)$, as expected. Similar results, except as noted below, were obtained for Trail Units B, D, E, H, K, L, N, O, and $Q$, which had slopes that changed with direction. Conversely, Trail Units C, F, G, $I, M, N N$, and $\mathrm{P}$ were relatively level (slopes less than 1.8 percent) and were considered to have no influence on speeds.

41. Several exceptions to the general trend in speeds occurred for the trail unit groupings listed above. For example, the M151A2, the M29C, and the M104 exhibited equal speeds in Trail Unit B in upslope and downslope directions. This event also occurred in several of the other trail units. Influence from various terrain-driver-vehicle interactions determined most of the speeds in each trail unit, although rapid vehicle acceleration capabilities enabled these lighter vehicles to attain a maxinum speed in each trail unit faster than some of the heavier vehicles, Consequently, for those trail units that were relatively smooth and with minimum slope, the M151A2, M29C, and M104 each attained approximately the same speed in upslope and downslope directions. 
42. The wheeled version of the Wheel/Track Test Rig generally followed the trend described above for the various trail units, in most cases exhibiting trail unit speeds faster than all vehicles tested, except the M151A2. The lighter M151A2 with a faster acceleration rate achieved faster average speeds in more trail units than did the Test Rig. The ride and handling qualities of the Test Rig were much better, however, than those of the M151A2. The uniquely suspended eight tires on the Test Rig produced smoother, firmer turning characteristics than the four-tire common suspension system used on the M151A2. The soft, low-pressure Terra-tires on the Test Rig combined with the torsilastic suspension through eight independent wheels to smooth abrupt bumps while maintaining a firm trail contact. The M151A2 with four standard military tires at 15-psi pressure bounced over most of the sharp bumps and slid around most of the sharp turns, requiring the driver to decrease speed to maintain vehicle control.

43. The average speed for each trail test was computed by dividing total traverse distance $(15,000 \mathrm{ft})$ by total time to complete the traverse. Results of this computation are shown at the bottom of table 2. The wheeled Test Rig, as indicated, was second only to the M151A2 in overa11 average speed. In the counterclockwise run, nearly equal or slightly faster speeds were achieved by most vehicles, possibly because only four trail units (B, K, L, and Q) sloped upward in the counterclockwise direction. However, average speeds for each vehicle in the $\mathrm{A}-\mathrm{Q}$ and $\mathrm{Q}-\mathrm{A}$ directions were within $1.1 \mathrm{mph}$ of each other.

\section{Traverse tests}

44. Results of traverse tests with each vehicle are shown in table 4. Speeds are shown for each vehicle in each terrain unit, along with the gear ranges used for most of the traverse. Included in table 5 is a typical terrain factor description. The low shrubs and low knolls in Terrain Unit 2 slowed all vehicles, except the Test Rig, as much as 1 to $3 \mathrm{mph}$, as compared with the other two units. The average speed for each vehicle is also included in this summary. Average speeds of 
the Test Rig in both wheeled and tracked modes were faster than those of all other vehicles tested. The slowest vehicle of all tested, the M274A2 with no suspension, was affected the most by the surface roughness; consequent1y, the speeds of the M274A2 were half those of the other vehicles tested. The other unsprung vehicle, the Wolverine, was the next slowest.

45. Descriptions of tests with both modes of the Test Rig, as described by the rider-observer, are included in table 6 . The ride and handling characteristics of the Rig were excellent in all three terrain units of Traverse 1. The tracked mode turned much more sharply than the wheeled, probably because of increased traction. The tracked ride, however, deteriorated somewhat from the wheeled ride because of the combined restraining action of the tracks and lock-out bars and increased tire pressure necessary for conversion from wheeled to track mode. The ride in both modes was as good as or better than the ride in al1 other vehicles.

Special-terrain tests

46. Muskeg tests. Repetitive traffic tests and genera1 maneuvering tests were conducted in muskeg with the wheeled and tracked Test Rig and the Wolverine. Results of repetitive traffic tests are shown in table 7. The Wolverine and wheeled Test Rig completed 22 and 16 passes, respectively, under similar test conditions. The lighter Wolverine (3160 lb versus $5600 \mathrm{lb}$ for the Test Rig) did complete more passes (6), as expected, but with rutting equivalent to that of the Test Rig on the same 0 - to 6-in. cone index. The softer underlying layer in the Wolverine test lane perhaps accounted for part of this difference. The Test Rig easily completed 50 passes with only shallow rutting.

47. General maneuvering tests were conducted with the Test Rig and two other vehicles (Wolverine and M29C) to obtain comparative information on relative performance of the Test Rig versus that of the other two vehicles. The Wolverine and the wheeled Test Rig both experienced difficulty in negotiating a sharp turn in the muskeg and were forced to resort to a slow-speed, wide, circular arc to complete 
a $360 \mathrm{deg}$ turn; ruts were 4 to $6 \mathrm{in}$. deep. The $\mathrm{M} 29 \mathrm{C}$ and the tracked Test Rig completed sharp, 25- to 30-ft-diam, 360-deg turns with ease and only slight rutting ( $<2$ in.). The tracked Test Rig seemed more aggressive in turning, cutting apart large pieces of the fibrous surface mat and tossing them aside. Both tracked vehicles easily accelerated in open areas and maneuvered easily around scrub vegetation growing in the organic bog. Ride in all vehicles at all speeds was comfortable, and at no time did slippage occur at the wheel-track interface on the Test Rig.

48. Stamped-sand tests. Maximum-speed, drawbar-pu11, and towedmotion-resistance tests were conducted with all vehicles in the finestamped-sand area at Gay. Results are presented in table 8 . Comparing wheeled vehicle performances in table 8 shows that the wheeled Test Rig (289-cu-in. engine) had the highest average speed and the highest maximum sustained drawbar pull, but the second highest towed motion resistance (in terms of percentage of gross vehicle weight). Comparing tracked vehicle performances in table 8 shows that the tracked Test Rig had the highest average speed, the lowest drawbar pulls, and the highest towed motion resistances. Probably the poor performance of the tracked Test Rig when compared with that of the other tracked vehicles can be attributed to track tension and the large area of wheel-track interface.

49. Slope-negotiability tests were conducted in an area of slightly coarser material north of the fine-tailings area. Results of these tests are presented in table 9. As indicated in table 9, a11 wheeled vehicles except the wheeled Test Rig were unable to negotiate a coarse-grained 33.6 percent slope. The wheeled Test Rig was able to negotiate a 38.8 percent slope at high wheel slip and was immobilized on a 46.0 percent slope. The tracked Test Rig negotiated al1 slopes before immobilizing on the 54 percent slope, although it experienced difficulty on the 46 percent slope that immobilized the wheeled version. The M104 was unable to negotiate the 46 percent slope and was relatively slow on all other slopes, compared with other tracked vehicles. The 
M29C was the best of a11 vehicles tested in negotiating the slopes, becoming immobilized on a 58 percent slope, although it experienced difficulty on the 54 percent slope.

\section{Tests at Vicksburg, Mississippi}

Albemarle Lake wooded, clay site

50. General maneuvering and handling tests were conducted in a very adhesive, alluvial buckshot clay at Vicksburg to analyze wheeltrack interaction after extensive mud buildup that occurred during testing. The major concern in these tests was the possibility of slippage at the wheel-track interface with sufficient mud buildup. However, this possibility was ruled out in these tests. Soil buildup measurements indicated an increase in vehicle weight of $1600 \mathrm{lb}$, or 24 percent of the gross vehicle weight, with no track slip. Vehicle maneuverability was not impaired, although the driver did comment on the sluggishness of the vehicle. He was not aware, however, that the vehicle weighed over $8300 \mathrm{lb}$ because of mud buildup. Photographic coverage of these tests supported the fact that no slip was experienced in the wheel-track system. The wheeled version of the Test Rig also performed rather well, although, not unexpectedly, it was somewhat hampered by traction difficulties. The wheeled version operated in the same soft-soil areas as the tracked version and suffered only one immobilization. This occurred near the water's edge in very soft soil, RCI $=11$. However, the wheeled vehicle almost completed the one pass on RCI of 11 necessary to establish the experimental $V_{1}$ of the wheeled version at approximately the computed $\mathrm{VCI}_{1}$ of 1 ( (table 12). The tracked version was not immobilized during these tests, although large quantities of mud accumulated in the vehicle running gear on $\mathrm{RCI}=11$. The computed $\mathrm{VCI}_{1}=9$ for the tracked version (table 12) was not verified by tests because of unavailability of a test area with RCI $<11$.

51. Three dynamics courses were selected at Parker's Farm to determine vehicle dynamic response at various speeds over three levels 
of surface roughness, $0.67,1.44$, and 1.49 in. (rms elevations), respectively. Time restrictions and nonavailability of courses precluded testing over a range of surface roughnesses, as is customary for development of a complete surface roughness-speed curve. Therefore, the results shown in fig. 16 reflect only preliminary test results. However, fig. 16 does indicate the outstanding ride performance of the Test Rig, in both modes, compared with that of two of the test vehicles used in this program. During traverse and trail tests at Houghton, both driver and rider-observer remarked on the smooth ride of the Test Rig. However, the vehicles were not tested over strictly ride dynamics courses for comparative purposes, and other vehicle factors over-... shadowed to some extent this particular vehicle attribute. Future testing, as scheduled in table A9 of the Plan of Tests (Appendix A), should provide sufficient information to analyze vehicle dynamic response more thoroughly and to finalize comparisons of ride qualities of the Test Rig with those of other vehicles.

Grassy slopes

52. Five grassy slopes, two clay at Albemarle and three silt at WES, were used for slope testing with the wheeled vehicles. As explained in paragraph 34, no speed tests were attempted with the tracked Test Rig. However, with sufficiently strong drive shafts the tracked version should outperform the wheeled on firm.grass slopes because of the added traction. Results of these slope tests are shown in table 10 . Side-slope tests conducted on the two clay slopes and the least silt slope produced no apparent detrimental effects on the vehicle. (The steepest" silt side slopes were not used for safety reasons.) The'vehicle performed well on the side slopes, with no wheel-track interface slip or side-slope slippage observed, either visually or through photographic coverage.

WES facility clay and sand pits

53. Five drawbar-pul1 and five towed-motion-resistance tests were conducted in the WES laboratory with the Test Rig in dry sand (SP) and buckshot clay $(\mathrm{CH})$ as presented in fig. 17. A test with the wheeled 


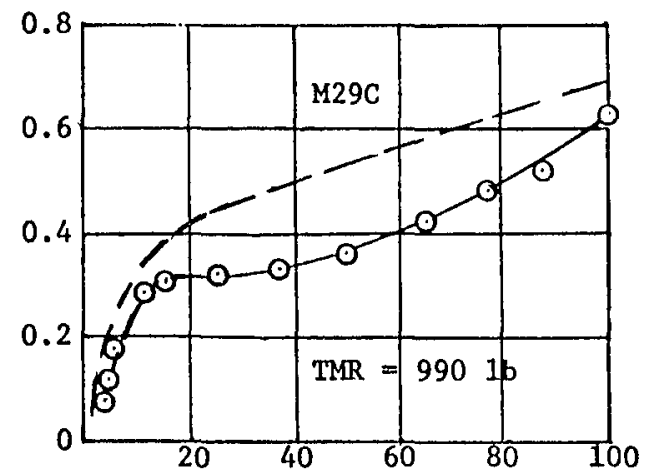

a. W/T tracked mode, $8 \times 8,15$ RCI sand

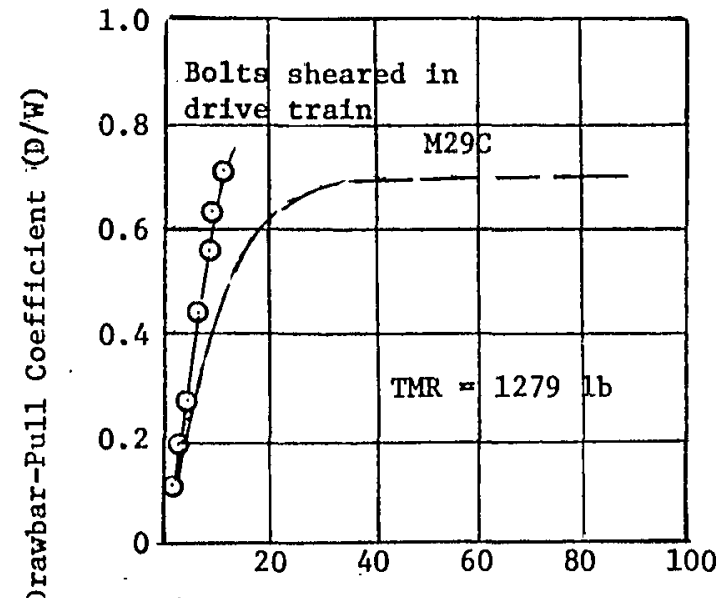

c. W/T tracked mode, $8 \times 8,36$ RCI clay

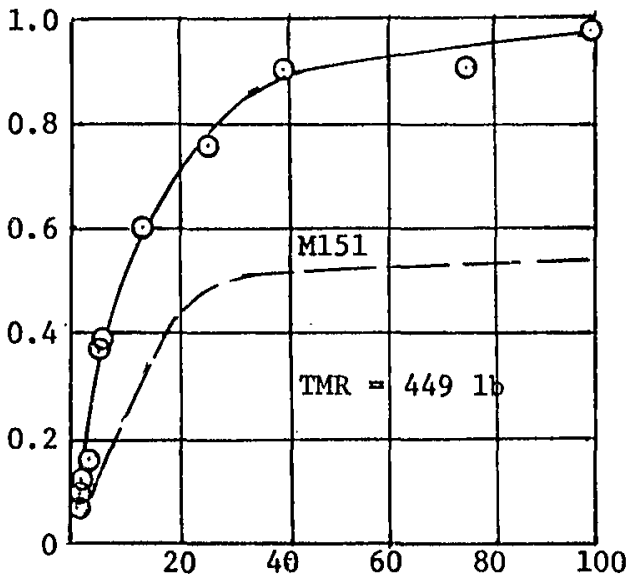

e. W/T wheeled mode, $8 \times 8,66$ RCI clay

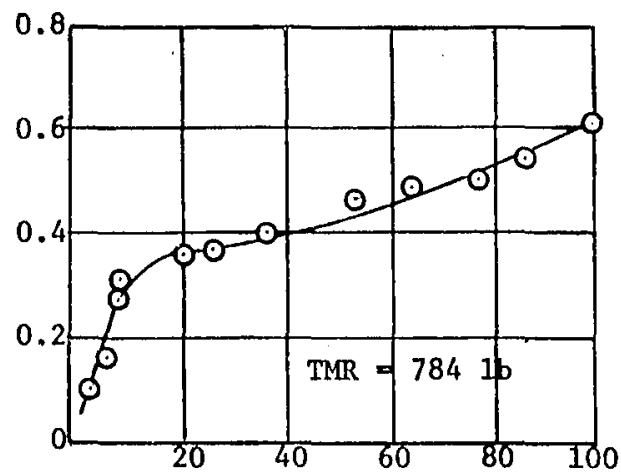

b. W/T tracked mode, $8 \times 4,15 \mathrm{RCI}$ sand

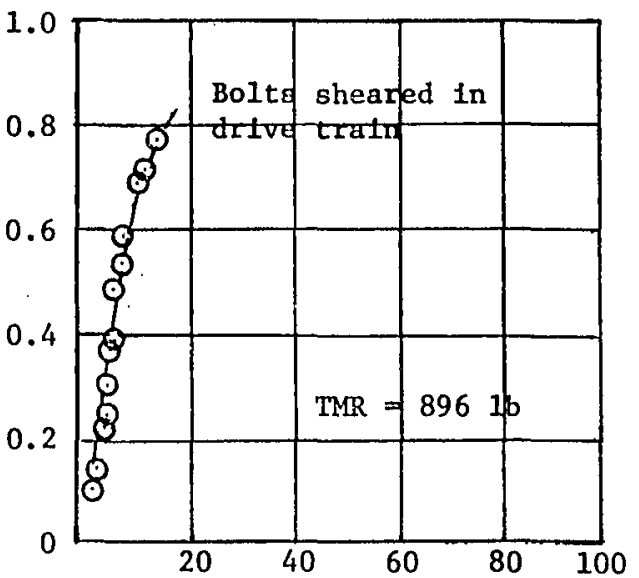

d. W/T tracked mode, $8 \times 4,36 \mathrm{RCI}$ clay

\section{Slip, \%}

Fig. 17. Drawbar-pull coefficient versus slip, W/T convertible and comparison vehicles, laboratory prepared sand and clay 
version only was conducted on a 66-RCI clay. During this test the drive shafts sheared as discussed in paragraph 39. At the time of shear, the vehicle was developing $53941 \mathrm{~b}$ of drawbar pul1, or a drawbar-pul1 coefficient $(D / W)$ of 0.96 , on relatively firm clay, an extremely high coefficient for any wheeled vehicle. For comparison, an average curve for the $\mathrm{M} 151$ on $66 \mathrm{RCr}$ is shown in fig. 17e. Note that the maximum $\mathrm{D} / \mathrm{W}$ for the $\mathrm{M} 151$ is near 0.54 , substantially less than 0.96. Tests on clay and sand with the tracked version of the Test Rig were conducted in $8 \times 8$ and $8 \times 4$ configurations to determine the effects of drawbar pull on the rear powered road arm in each set. No significant effects could be determined from these tests, although the $8 \times 4$ seemed to develop more pull at lower slip values in sand. Also drawbar pulls in both configurations are slightly less than those pulls of the M29C weasel at equal slip values. The $8 \times 8$ and $8 \times 4$ tracked Test Rigs were unable to complete the drawbar-pull tests on the 36-RCI clay. The "shear-pin" system failed in both tests at drawbar-pull values less than maximum. Therefore, no firm conclusions can be reached from the 36-RCI tests, although the curves indicate pulls in excess of those of the M29C comparison vehicle. 
PART V: CONCLUSIONS AND RECOMMENDATIONS

\section{Conclusions}

54. The results of the test program with the Interim Whee1/Track Convertible Test Rig may be summarized as follows:

a. The Test Rig performed well in a variety of terrain conditions, generally equaling or exceeding the performance of both the wheeled and tracked comparison vehicles in the respective modes. Vehicle ride and handling characteristics are two of the most promising features of the vehicle, permitting relatively rapid speeds over rugged terrain at comfortable ride levels.

b. The powered, suspended road arm system on the Test Rig was found to be practlcal, especially in the wheeled mode. Some mechanical problems occurred in initial tests with the tracked mode, but were not unique for a firstgeneration vehicle.

c. In trail tests the power train of the Test Rig appeared inadequate in rapidly accelerating between turns and obstacles and in maneuvering. The vehicle outperformed a11 vehicles except the M151A2. The Test Rig ride was much firmer, yet more comfortable than that of the M151A2, a1though insufficient acceleration of the Test Rig prevented the vehicle from exceeding the speeds attainable by the M151A2 (paragraphs 42 and 43).

d. During all phases of testing, the track wrap-around concept proved effective in increasing drawbar pul1, slope negotiability, maneuverability, and soft-soil performance compared with those of the wheeled version. At no time did the track slip off the tires, nor did slip occur at the wheel-track interface (paragraphs 45-50, 53). 
e. The Wheel/Track Convertible Test Rig concept appears practicable, and IImited performance tests herein suggest a fu1l-scale test program after final modifications of the Rig (paragraphs $42-50,52,53$ ).

\section{$\underline{\text { Recommendations }}$}

55. It is recommended that:

a. Any excessive weight be removed from the Test Rig to permit faster accelerations, or a more efficient and powerful power train be installed for future tests.

b. Future test programs, as outlined in the plan of tests, (Appendix A) be implemented, following any redesign modifications deemed necessary as a result of these tests. 
Table 1

Summary of Terrain Data, TACOM Trail Course 2 (Clockwise)

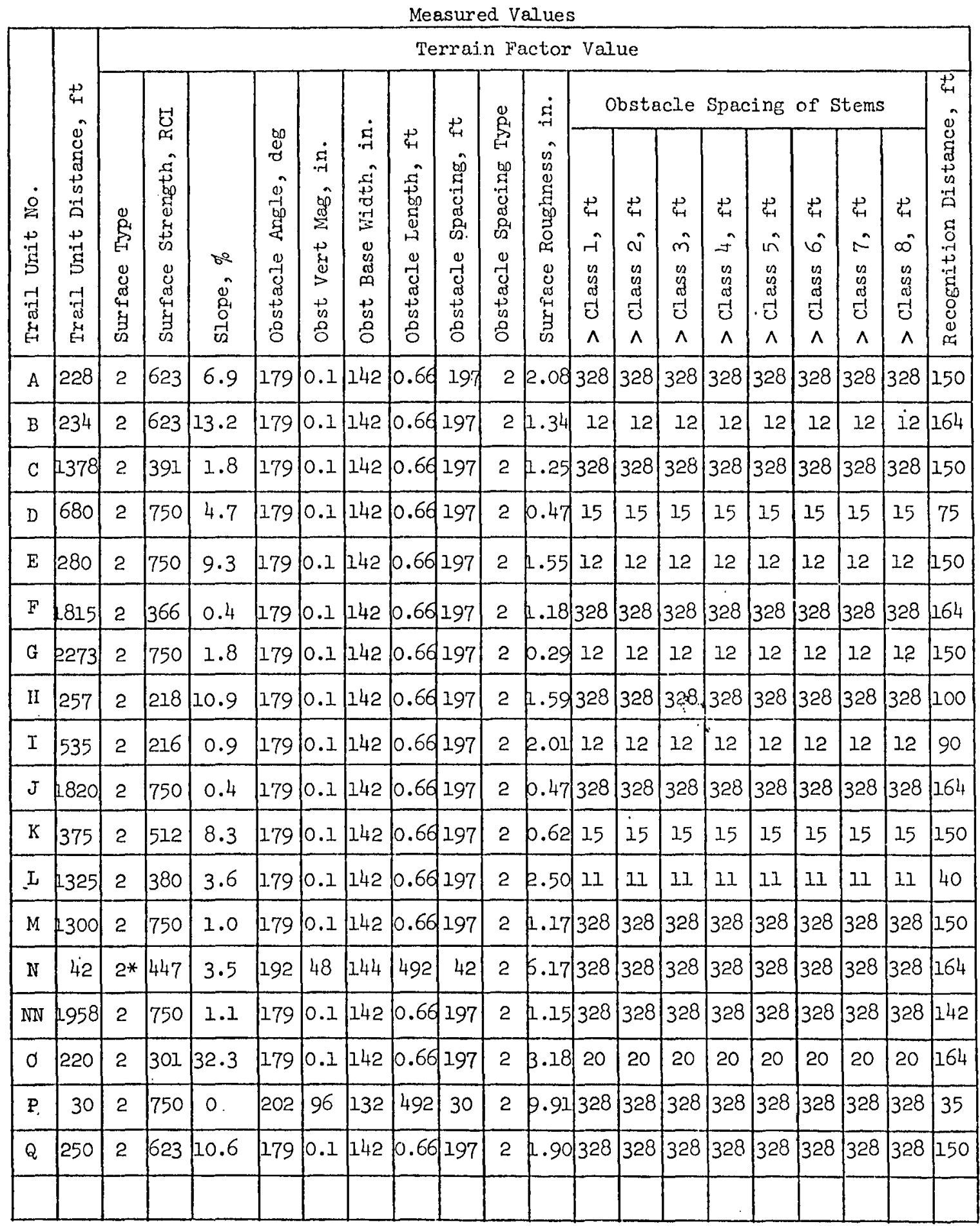

* Stream crossing.

(Continued) 
Table 1 (Concluded)

Factor Classes

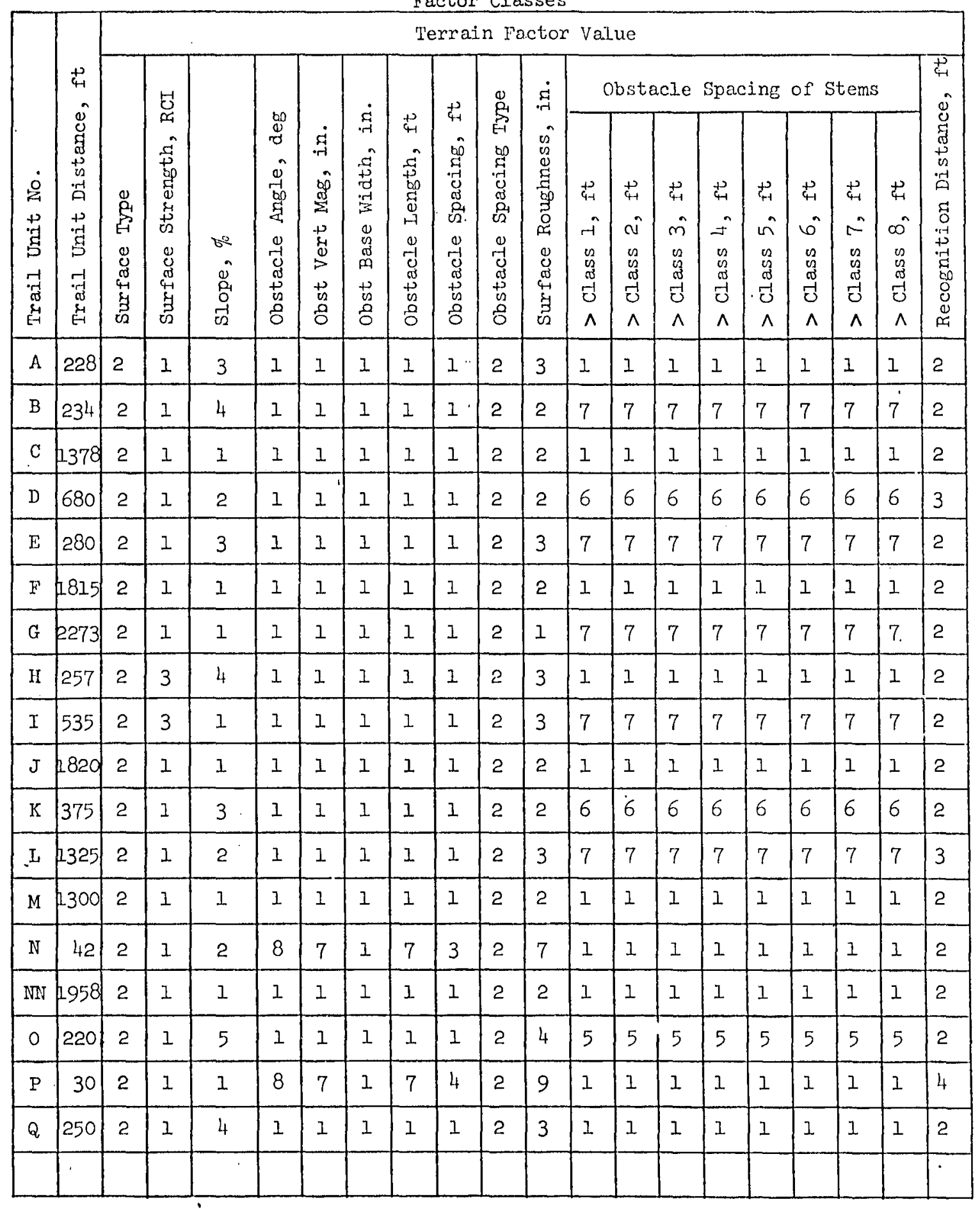


Table 2. TACOM Trail Course 2, Average Spe:sds, mph

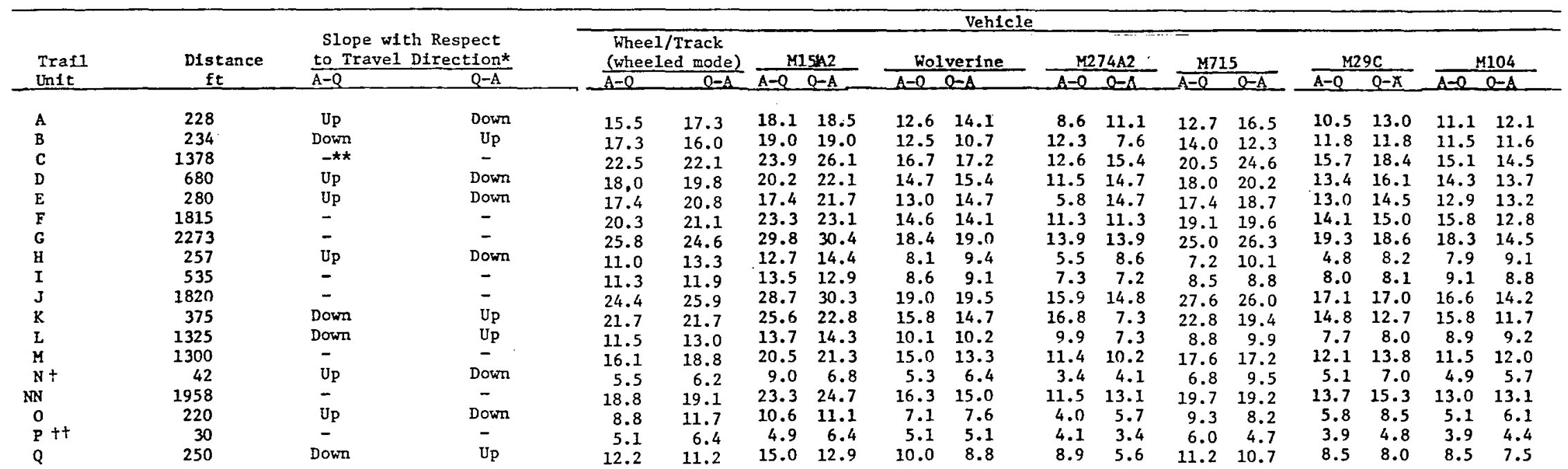

\begin{tabular}{llllllllllllllllllllllllllll}
\hline Trail & 15,000 & 17.8 & 18.9 & 20.9 & 21.6 & 14.2 & 14.1 & 11.0 & 11.0 & 16.6 & 17.4 & 12.5 & 13.6 & 12.9 & 12.1
\end{tabular}

* Vehicles were run clockwise $(A-Q)$ and counterclockwise (Q-A) around closed loop of Trail course to determine effects of vehtcle passage in both directions in trail units.

** Dashes indicate negligible slope.

+ Stream crossing.

t† Road crossing. 


\begin{tabular}{|c|c|c|c|c|}
\hline $\begin{array}{l}\text { Trall } \\
\text { Un1t } \\
\text { IFo. } \\
A\end{array}$ & $\begin{array}{c}\begin{array}{c}\text { frail } \\
\text { Unit } \\
\text { Length, ft }\end{array} \\
\frac{228}{28}\end{array}$ & $\begin{array}{l}\text { Time in } \\
\text { Tra11 } \\
\frac{\ln 15}{10.0} \text { sec }\end{array}$ & $\begin{array}{l}\text { Ave Speed } \\
\text { 1nt trail } \\
\frac{\text { Unit, mph }}{15.5}\end{array}$ & $\begin{array}{c}\text { Tra11 Factore } \\
\text { Exerting Host } \\
\text { Influence on Speed }\end{array}$ \\
\hline B & 234 & 9.2 & 17.3 & $\begin{array}{l}12^{\prime} \text { wide tra11, } 13.22 \text { downs lope. } \\
\text { Some surface roughness }\end{array}$ \\
\hline $\mathrm{c}$ & 1378 & 41.8 & 22.5 & Some surface roughness \\
\hline
\end{tabular}

12' w1de trall

10.97 ups lope; visibil1ty cut to $100^{\prime}$ by vegetation

$11.3 \quad 12^{\prime}$ wide trail; visibility in very frregular and rough

15' wide tra11; 8.37 downslope. Some roughness problem

$11.5 \quad 11^{\prime}$ wide trat1; $3.6 \%$ downs lope. Maneuver caused by close proxfratty of large trees to eige of trail; visibility cut to $40^{\circ}$ (stream banks)

Surface roughness; 32.37 upslope

U-shaped road crossing presented surface roughness and obstacle $\frac{\text { Notes and Obaervations of Rider/Observer Durtng Test }}{\text { Speed at start of trall unit } 15 \mathrm{mph} \text { up slope; speed up to } 20 \mathrm{mph}}$ near road crossing at "B"; driver slowed slightly before golng downs lope at "B"

Speed downslope $17 \mathrm{mph}$; some slight roughness but rlde very good, suspension very effective in minlmizing abrupt bumps

Speed at start of unit $20 \mathrm{mph}$; some vehicle side-skid on loose material, but handling and stability of vehicle excellent. Accelmaterial, but handling and stability of vehicle excellent. Acceleration in loose material with surface roughnesa falr. Speed in-
creased to $28 \mathrm{mph}$ near end of terrain unit. Crossed bridge over creek at approximately 15 mph.

Agaln vehicle "slid" around turn at " $D$ ", but handling and otability very good. Speed down to $9 \mathrm{mph}$ after skid, but driver accelerated to 24 mph before malntaining constant $20 \mathrm{mph}$ for rema1nder of terraln unit; alowed to $15 \mathrm{mph}$ for left curn at $\mathrm{E}$

Vehicle accelerated at $16 \mathrm{mph}$ from $\mathrm{E}$, reach1ng $20 \mathrm{mph}$ near crest of slope at $F$

Some side skid on green grass at F. Driver accelerated in open fleld to $25 \mathrm{mph}$ before surface roughness held speed to 22-25. Suspension very effective in maintaining smooth ride over rough surface irregularities. Driver had to $810 \mathrm{w}$ to $11 \mathrm{mph}$ to complete $360^{\circ}$ loop at end of field.

Speed at "G" of $17 \mathrm{mph}$. Accelerated along virtual "tunne l" In vegetation ovet smooth trall to $30 \mathrm{mph}$. Held this speed for mafortty of tratl unit, slowing at " $\mathrm{H}$ " to $7 \mathrm{mph}$ to go upslope

Speed up slope of $7 \mathrm{mph}$. Speed in maneuver area before "I" about 12-15 mph.

Speed entering unft $13 \mathrm{mph}$. Some "bottoming" on jounce stops over roughest bumps, but suspension remsins very effective in mintmizing harsh folts over edges of Irregulartities. Driver alternately pushed gas pedal between surface features and released pedal at features to reduce impact on Jounce stops. Some slight maneuvering in addition to surface roughness held speed to $11 \mathrm{mph}$ most of unit.

This trafl unit is actually a sandy tertlary road. Vehfcle acceleration probably influenced average speed in the unit the most. Entered unlt at $12 \mathrm{mph}$. Rapldly accelerated to $30 \mathrm{mph}$ and maintained about this speed for most of the untt. Slowed to $25 \mathrm{mph}$ as approached " $K$ ".

Entered trail unit at 25 mph but driver gradually slowed vehicle because of downslope and anticipated sharp left turn at "L"

Speed governed by maneuver in waods along a narrow trall; entered unit at $11 \mathrm{mph}$, but speed cut to about $8-10 \mathrm{mph}$ by maneuver, vistbility and roughness. Speeds up to 10-12 mph between turns and maneuvers.

Entered atamped rock area at about $12 \mathrm{mph}$. Accele rated to $22 \mathrm{mph}$ rapldly but slowed somewhat by maneuver around small trees, Slowed to about $14 \mathrm{mph}$ upon approach to creek crossing at " $\mathrm{N}$ "

Entered creek at $13 \mathrm{mph}$. Water depth 12" with rocky stream bottom. Steep stream bank at "NN". Some wheel slip on bank caused by wave action during crossing.

Entered atamped rock area again at 4-6 mph. Accelerated rapidiy to conscanc 14 mph for maneuver in small stand of pines. Exited pine area and accelerated on stamped rock to $24 \mathrm{mph}$. Speed slowed at times to $20 \mathrm{mph}$ by surface irregularities.

Upsiope on steep gandy surface at $8 \mathrm{mph}$. Speed down to $5-6 \mathrm{mph}$ at crest of slope. Driver accelerated silghtly on flat area between crest of slope and top of bank at edge of road

Driver slowed at bank edge and eased down onto road bed about $6 \mathrm{mph}$. Speed down to 4-5 mph at top of opposite bank.

Driver accelerated downslope toward end of test. Some surface 1rregulartites slowed apeed down to $12-15$ mph near end of test. 


\begin{tabular}{|c|c|c|c|c|c|}
\hline $\begin{array}{l}\text { Trail } \\
\text { Un1t } \\
\text { No. }\end{array}$ & $\begin{array}{l}\text { Trat1 } \\
\text { Unit } \\
\text { Length, ft }\end{array}$ & $\begin{array}{l}\text { Time in } \\
\text { Trall } \\
\text { Unit, sec }\end{array}$ & $\begin{array}{l}\text { Avg Speed } \\
\text { In Trail } \\
\text { Unit, mpin }\end{array}$ & $\begin{array}{l}\text { Trafl Factors } \\
\text { Exerting Most } \\
\text { Influence on Speed }\end{array}$ & Notes and Obgervations of Rider/observer Durtng Test \\
\hline$Q$ & 250 & 15.2 & 11.2 & $\begin{array}{l}\text { Surface roughness; } 10.6 x \\
\text { ups lope }\end{array}$ & $\begin{array}{l}\text { Speed at acart of trall unit } 15 \text { mph; ups lope at } 10 \mathrm{mph} \text { after turn } \\
\text { towards } Q ; \text { some surface roughness }\end{array}$ \\
\hline$P$ & 30 & 3.2 & 6.4 & $\begin{array}{l}\text { U-shaped road crossing pre- } \\
\text { gented surface roughness \& ob- } \\
\text { stacle problems; vistbility } \\
\text { only } 30 \mathrm{ft}\end{array}$ & $\begin{array}{l}\text { Driver slowed at bank edge to about } 6 \mathrm{mph} \text {. Eased down onto road and } \\
\text { then bitck up other bank at } 4-5 \mathrm{mph} \text {. }\end{array}$ \\
\hline 0 & 220 & 12.8 & 11.7 & $\begin{array}{l}\text { Surface roughness: } 32.37 \\
\text { downslope. }\end{array}$ & $\begin{array}{l}\text { Drtver eased over crest at } 8 \text { mph; held brake until mbout half-way } \\
\text { down slope, then driver allowed veh1cle to roll down remalnder of } \\
\text { slope, galning speed as vehicle passed "O" about } 15 \mathrm{mph}\end{array}$ \\
\hline $\mathrm{mm}$ & 1958 & 70.0 & 19.1 & Surface roughness & $\begin{array}{l}\text { When vehicle entered atamped rock area driver began accelerating; } \\
\text { vehlcle speed up to } 24-26 \text { mph which driver held for majority of } \\
\text { trall unit; slowed to } 15 \text { mph in pine area before creek to maneuver }\end{array}$ \\
\hline N & 42 & 4.6 & 6.2 & $\begin{array}{l}\text { Surface roughness; obatacles } \\
\text { (Btream banks) }\end{array}$ & $\begin{array}{l}\text { Driver alowed vehicle to } 4-6 \mathrm{mph} \text { before entering water; exited water } \\
\text { at } 6 \mathrm{mph}\end{array}$ \\
\hline M & 1300 & 47.2 & 18.8 & Surface roughness; maneuver & $\begin{array}{l}\text { Accelerated away from creek up to } 15-16 \mathrm{mph} \text {; maneuver in ptnes out } \\
\text { onto atamped rock at } 21 \mathrm{mph} \text {; speed } 19-20 \mathrm{mph} \text { in turns and } 24-25 \mathrm{mph} \\
\text { on stratght portlone of tral1; 26-27 mph before slowing to enter } \\
\text { woods at } 18 \mathrm{mph}\end{array}$ \\
\hline $\mathbf{L}$ & 1325 & 69.4 & 13.0 & $\begin{array}{l}\text { 11' wlde trall; } 3.6 \% \text { upulope; } \\
\text { maneuver caused by close prox- } \\
\text { imlty of large trees to trall } \\
\text { edge. Vislbillty only } 40^{\prime} \text {. }\end{array}$ & $\begin{array}{l}\text { Speed cut to } 8 \text { mph by maneuver and narrow trall; up to } 10-11 \text { mph on } \\
\text { straight portions of trafli some gurface roughness. Accelerated to } \\
18 \mathrm{mph} \text { before entering area requiring most maneuver. Speed } 11 \text { to } \\
13 \mathrm{mph} \text { in this area. }\end{array}$ \\
\hline $\mathrm{k}$ & 375 & 11.8 & 21.7 & $\begin{array}{l}\text { 15' wide trafl; } 8.37 \text { upslope; } \\
\text { wo surface roughness }\end{array}$ & $\begin{array}{l}\text { After turning onto trail from woods at } 13 \mathrm{mph} \text {, driver accelerated up- } \\
\text { slope to } 22 \mathrm{mph} \text { for remalnder of trail unit. }\end{array}$ \\
\hline $\mathbf{J}$ & 1820 & 48.0 & 25.9 & None & $\begin{array}{l}\text { Acceleration Influenced speed most. Driver entered terrain unit at } \\
\text { much faster speed than he did on clockwise test A-Q. Speed } 30 \mathrm{mph} \\
\text { most of tratl unit. }\end{array}$ \\
\hline I & 535 & 30.6 & 11.9 & $\begin{array}{l}12^{\prime} \text { wide trati; v1siblitty } 90^{\circ} \\
\text { surface very irregular and } \\
\text { rough }\end{array}$ & $\begin{array}{l}\text { Surface roughness held speed to } 10-12 \text { mph for entire unit. Driver } \\
\text { accelerated between 1rregularitiea but eased off on gas over Ir- } \\
\text { regularities to lessen abruptness of butaps. Ride otill rather } \\
\text { comfortable. }\end{array}$ \\
\hline H & 257 & 13.2 & 13.3 & $\begin{array}{l}10.9 x \text { downslope; vilbillty of } \\
100^{\circ}\end{array}$ & $\begin{array}{l}\text { Entered trall unit at } 10-12 \mathrm{mph} \text { but speed increased downslope to } \\
15 \text { mph before turn Into terraln unit "G" }\end{array}$ \\
\hline G & 2273 & 63.0 & 24.6 & $12^{*}$ wide trall & $\begin{array}{l}\text { Accelerated up to } 30 \mathrm{mph} \text { and held this speed for most of unit. Speed } \\
\text { down to } 26 \text { for turna. }\end{array}$ \\
\hline$p$ & 1815 & 58.6 & 21.1 & Surface roughness & $\begin{array}{l}\text { Slowed to } 18 \mathrm{mph} \text { for turn at " } \mathrm{G} \text { ". Surface roughness and turning held } \\
\text { speed to } 14 \mathrm{mph} \text { for loop turn-around. Accelerated to } 30 \text { in open fiet } \\
\text { before surface roughness cut speed to } 20 \mathrm{mph} \text {. Ride good over } \\
\text { roughest areas. }\end{array}$ \\
\hline E & 280 & 9.2 & 20.8 & $\begin{array}{l}12^{\prime} \text { wide tratl; one surface } \\
\text { roughness, } 9.3 \% \text { downslope }\end{array}$ & $\begin{array}{l}\text { Entered unit at } 25 \mathrm{mph} \text { but slowed to } 22 \mathrm{mph} \text { going downhll1. Speed } \\
\text { down to } 15 \mathrm{mph} \text { for turn into "D". }\end{array}$ \\
\hline D & 680 & 23.4 & 19.8 & $\begin{array}{l}15^{\prime} \text { wide tra11; visibillty only } \\
75^{\prime} ; \text { some surface roughness }\end{array}$ & $\begin{array}{l}\text { Accelerated on rocky curface from } 15 \text { mph to } 22 \text { before vehicle began } \\
\text { sliding around turns. Driver slowed to } 12-15 \text { mph for turn at bridge. }\end{array}$ \\
\hline c & 1378 & 42.6 & 22.1 & Some surface roughness & $\begin{array}{l}\text { Crossed bridge at } 15 \text { mph and onto atamped rock area where driver ec- } \\
\text { celerated to } 30 \text { mph. Skid on turns cut speed to } 24-26 \mathrm{mph} \text {. Speed } \\
\text { down to } 18 \mathrm{mph} \text { for turn up slope into "B". }\end{array}$ \\
\hline B & 234 & 10.0 & 16.0 & $\begin{array}{l}12 \text { ' wide trall; } 13.2 \% \text { upslope; } \\
\text { some surface roughness }\end{array}$ & $\begin{array}{l}\text { Entered trail unit at } 18 \mathrm{mph} \text {; speed slowed to } 15-16 \mathrm{mph} \text { upslope by } \\
\text { slope \& roughness. }\end{array}$ \\
\hline A & 228 & 9.0 & 17.3 & 6.97 downs lope & $\begin{array}{l}\text { Driver pasaed crest of slope at } 16 \mathrm{mph} \text { and accelerated toward end of } \\
\text { tegt. Slight turn near end of test slowed speed down allghtly from } \\
20 \mathrm{mph} \text {. }\end{array}$ \\
\hline
\end{tabular}


Table 4

Traverse Speed Tests

Traverse 1, Ahmeek, Michigan

\begin{tabular}{|c|c|c|c|c|c|}
\hline \multirow[b]{2}{*}{ Vehicle } & \multirow[b]{2}{*}{ Gear or Range } & \multicolumn{4}{|c|}{ Speed, mph } \\
\hline & & $\begin{array}{l}\text { Terrain } \\
\text { Unft } 1 \\
\end{array}$ & $\begin{array}{l}\text { Terrain } \\
\text { Unit } 2 \\
\end{array}$ & $\begin{array}{l}\text { Terrain } \\
\text { Unit } 3 \\
\end{array}$ & $\begin{array}{c}\text { Average } \\
\text { Speed }\end{array}$ \\
\hline \multicolumn{6}{|c|}{ Wheeled } \\
\hline Wheel/Track Test Rig & High-Drive & 19.3 & 17.1 & 16.7 & 17.4 \\
\hline M151A2 & 2nd or $3 \mathrm{rd}$ & 17.9 & 15.1 & 18.2 & 17.1 \\
\hline Wolverine & 2nd & 14.9 & 11.3 & 12.5 & 12.5 \\
\hline M274A2 & HIgh-1st & 8.6 & 7.0 & 7.4 & 7.5 \\
\hline M715 & 2nd or 3 rd & 14.0 & 12.5 & 13.8 & 13.4 \\
\hline \multicolumn{6}{|c|}{ Tracked } \\
\hline Wheel/Track Test Rig & High-Drive & 18.4 & 17.3 & 17.1 & 17.5 \\
\hline M29C & High-1st \& 2nd & 14.9 & 11.9 & 15.3 & 14.0 \\
\hline M104 & Low-Drive & 14.0 & 12.5 & 13.8 & 13.4 \\
\hline
\end{tabular}

Table 5

Summary of Terrain Data Traverse 1

\begin{tabular}{|c|c|c|c|c|c|c|c|c|c|c|c|c|c|c|c|c|c|c|c|c|}
\hline \multirow[b]{2}{*}{ 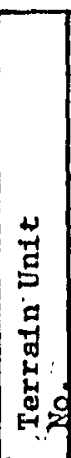 } & & \multicolumn{19}{|c|}{ Terrain Factor Value } \\
\hline & 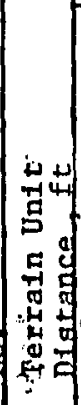 & . & 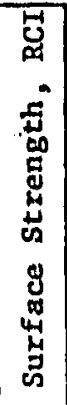 & 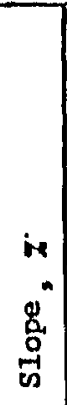 & 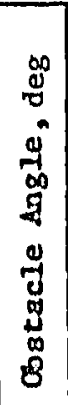 & 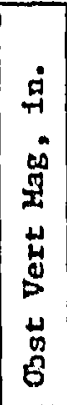 & 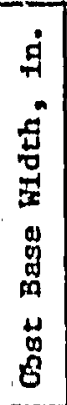 & 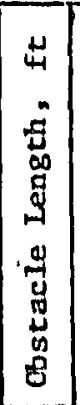 & 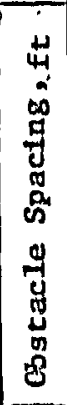 & 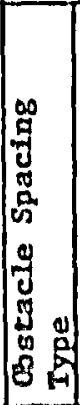 & 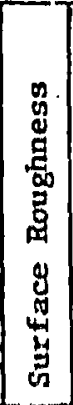 & 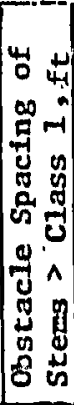 & 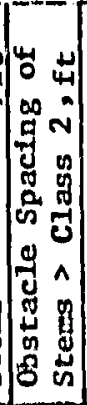 & 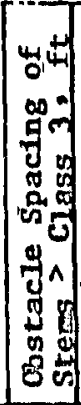 & 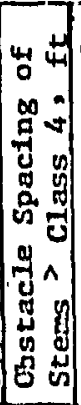 & 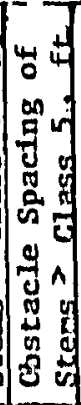 & 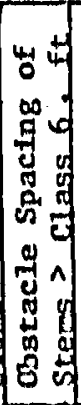 & 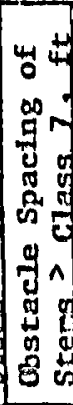 & 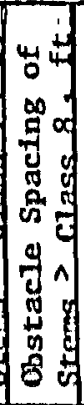 & 列 \\
\hline 1 & 550 & 2 & 255 & 1.7 & 179 & 0.1 & 142 & 0.66 & 197 & 2 & $1,8 ?$ & 328 & 328 & 328 & 328 & 328 & 328 & 320 & 328 & 50 \\
\hline 2 & 750 & 2 & 288 & 2.6 & 179 & 0.1 & 142. & 0.66 & 197 & 2 & 1.60 & 11.2 & 14,4 & 24.1 & 32.7 & 328 & 328 & 328 & 328 & 38 \\
\hline 3 & 1046 & 2 & 231 & 0.6 & 179 & 0.1 & 142 & 0.66 & 197 & 2 & 2.14 & 328 & 328 & 328 & 328 & 328 & 328 & 328 & 1328 & 49 \\
\hline & & & & & & & & & & & & & & & & & & & & \\
\hline
\end{tabular}


Table 6

Test Notes, Traverse 1, Ahmeek, Michigan, Wheeled/Tracked Convertible Test R1k.

\begin{tabular}{|c|c|c|c|c|c|}
\hline $\begin{array}{l}\text { Terrain } \\
\text { Unit } \\
\text { No. } \\
\end{array}$ & $\begin{array}{l}\text { Terrain } \\
\text { Unit } \\
\text { Length, ft }\end{array}$ & $\begin{array}{l}\text { Tine in } \\
\text { Terrain Unit } \\
\text { sec }\end{array}$ & $\begin{array}{l}\text { Avg Speed in } \\
\text { Terraln Unit } \\
\text { mph } \\
\end{array}$ & $\begin{array}{c}\text { Terrain Factors } \\
\text { Exerting Most Influence } \\
\text { on Speed } \\
\end{array}$ & Notes and Observations of Rider-Observer During Test \\
\hline \multicolumn{6}{|c|}{ Wheeled Mode } \\
\hline 1 & 550 & 19.4 & 19.3 & $\begin{array}{l}\text { Surface roughness; } \\
\text { visibility }\end{array}$ & $\begin{array}{l}\text { Speed at start of test }-22 \mathrm{mph} \text {; ride and stability good; speed } \\
\text { up to } 24 \mathrm{mph} \text { near mid-point of terrain unit; surface roughess } \\
\text { Increased as vehicle approached end of terraln unit; spoed } 18 \mathrm{mph}\end{array}$ \\
\hline 2 & 750 & 30.0 & 17.1 & $\begin{array}{l}\text { Surface roughness; } \\
\text { maneuver; visib1lity }\end{array}$ & $\begin{array}{l}\text { Jounce stopg hit hard in rocky area near smatl trees, speed } \\
16-17 \mathrm{mph} \text {; diver maneuvered around trees and over small rocky } \\
\text { knolls at 16-20 mph; handling of vehlcle excellect, ride } \\
\text { comfortable }\end{array}$ \\
\hline 3 & 1046 & 42.6 & 16.7 & $\begin{array}{l}\text { Surface roughness; } \\
\text { viablitty }\end{array}$ & $\begin{array}{l}\text { Speed at start of undt } 20 \mathrm{mph} \text {; roughness slowed speed to } 16-17 \mathrm{mph} \\
\text { for remafnder of test; ride sometimes degraded by severity of } \\
\text { bumps, but overall, still good }\end{array}$ \\
\hline \multicolumn{6}{|c|}{ Tracked Mode } \\
\hline 1 & 550 & 20.4 & 28.4 & $\begin{array}{l}\text { Surface roughness; } \\
\text { visiblity }\end{array}$ & $\begin{array}{l}\text { Speed at start of test } 26 \mathrm{mph} \text {; ride as good as that of wheeled } \\
\text { node; speed up to } 30 \mathrm{mph} \text { in middle of terrain unit, down to } \\
16-20 \text { mph near Terrain Unit } 2\end{array}$ \\
\hline 2 & 750 & 29.6 & 17.3 & $\begin{array}{l}\text { Surface roughness; } \\
\text { maneuver; visib1lity }\end{array}$ & $\begin{array}{l}\text { Entered Unit } 2 \text { at } 25 \mathrm{mph} \text {; vehicle maneuvers around trees sharper } \\
\text { than wheeled mode, probably from lncreased traction; speed over } \\
\text { rocky knolls } 16-20 \mathrm{mph}\end{array}$ \\
\hline
\end{tabular}

Table 7

Confined Muskeg Trafficability Tests

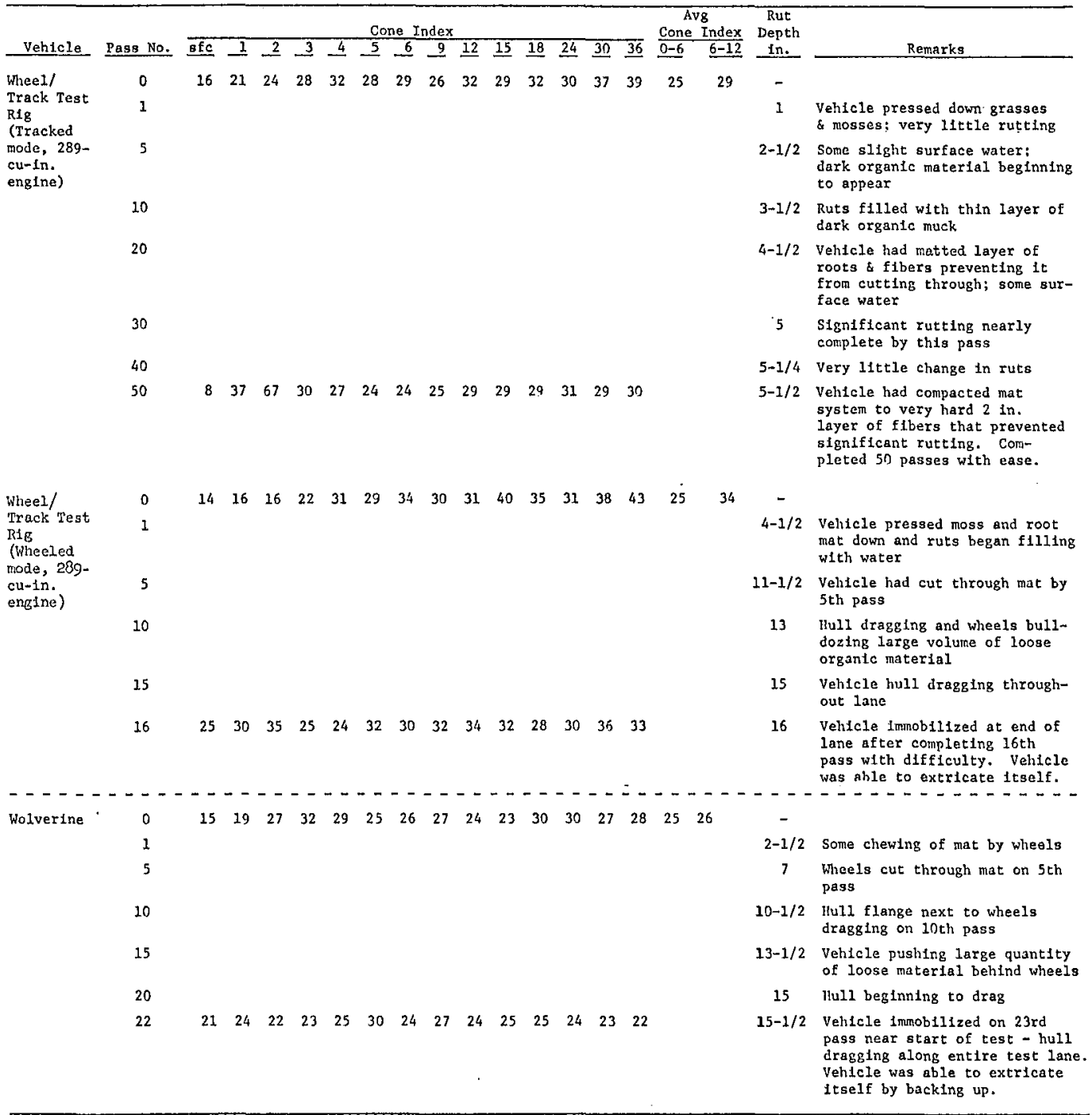


Results of Speed, Drawbar-Pul1, and Towed-Motion-Resistance Tests Stamped Sand, Gay, Michigan

\begin{tabular}{|c|c|c|c|c|c|c|}
\hline \multirow[b]{2}{*}{ Vehicle } & \multirow[b]{2}{*}{$\begin{array}{l}\text { Gear or } \\
\text { Range }\end{array}$} & \multirow[b]{2}{*}{$\begin{array}{l}\text { Avg speed, } \\
\mathrm{mph} \\
\end{array}$} & \multicolumn{2}{|c|}{$\begin{array}{l}\text { Maximum Sustained } \\
\text { Drawbar Pul1 }\end{array}$} & \multicolumn{2}{|c|}{$\begin{array}{l}\text { Avg Towed Motion } \\
\text { Resistance } \\
\end{array}$} \\
\hline & & & 16 & $\begin{array}{l}\text { Percent of } \\
\text { Gross Wt } \\
\end{array}$ & $1 \mathrm{~b}$ & $\begin{array}{l}\text { nercent of } \\
\text { Gross Wt }\end{array}$ \\
\hline \multicolumn{7}{|c|}{ Wheeled } \\
\hline $\begin{array}{l}\text { Wheel/Track } \\
\text { Test Rig, } \\
\text { (141-cu-in. } \\
\text { engine) }\end{array}$ & $\begin{array}{l}\text { High-Drive } \\
\text { Low-Drive }\end{array}$ & $\begin{array}{l}18.8 \\
19.7\end{array}$ & 1900 & 33.9 & 440 & 7.8 \\
\hline $\begin{array}{l}\text { (289-cu-in. } \\
\text { engine) }\end{array}$ & High-Drive & 36.9 & 1900 & 33.9 & 440 & 7.8 \\
\hline M15IA2 & $3 r d$ & $29.7 * *$ & 560 & .17 .5 & 220 & 6.9 \\
\hline Wolverine & $3 r d$ & 27.1 & 900 & 28.8 & 460 & .14 .5 \\
\hline $\mathrm{M} 274 \mathrm{~A} 2$ & $\begin{array}{l}\text { High-2nd } \\
\text { Low-3rd }\end{array}$ & $\begin{array}{l}14.2 \\
11.5\end{array}$ & 520 & 24.8 & 120 & 5.7 \\
\hline \multicolumn{7}{|c|}{ Tracked } \\
\hline $\begin{array}{l}\text { Wheel/Track } \\
\text { Test Rig, } \\
\text { (141-cu-in. } \\
\text { engine) }\end{array}$ & \multicolumn{6}{|c|}{ Inoperable - mechanical difficulties } \\
\hline $\begin{array}{l}\text { (289-cu-in. } \\
\text { engine) }\end{array}$ & High-Drive & 24.6 & 2300 & 34.3 & 800 & 11.9 \\
\hline $\mathrm{M} 29 \mathrm{C}$ & $\mathrm{High}-2 \mathrm{nd}$ & 23.0 & 3000 & 52.6 & 400 & 7.0 \\
\hline M104 & High-Drive & 20.5 & 2400 & 41.7 & 430 & $7.5^{\prime}$ \\
\hline \multicolumn{7}{|c|}{$\begin{array}{l}\text { * In the motion-resistance tosts, the vehicle transmission was in } \\
\text { neutral. }\end{array}$} \\
\hline \multicolumn{7}{|c|}{$\begin{array}{l}\text { ** The M151^2 used in this test was experiencing carburetor problems. } \\
\text { The vehicle was repalred after these tests, but another speed test } \\
\text { was not conducted. The spoed shown does not reflect the maximum } \\
\text { pexformance of a standard M151A2. }\end{array}$} \\
\hline
\end{tabular}




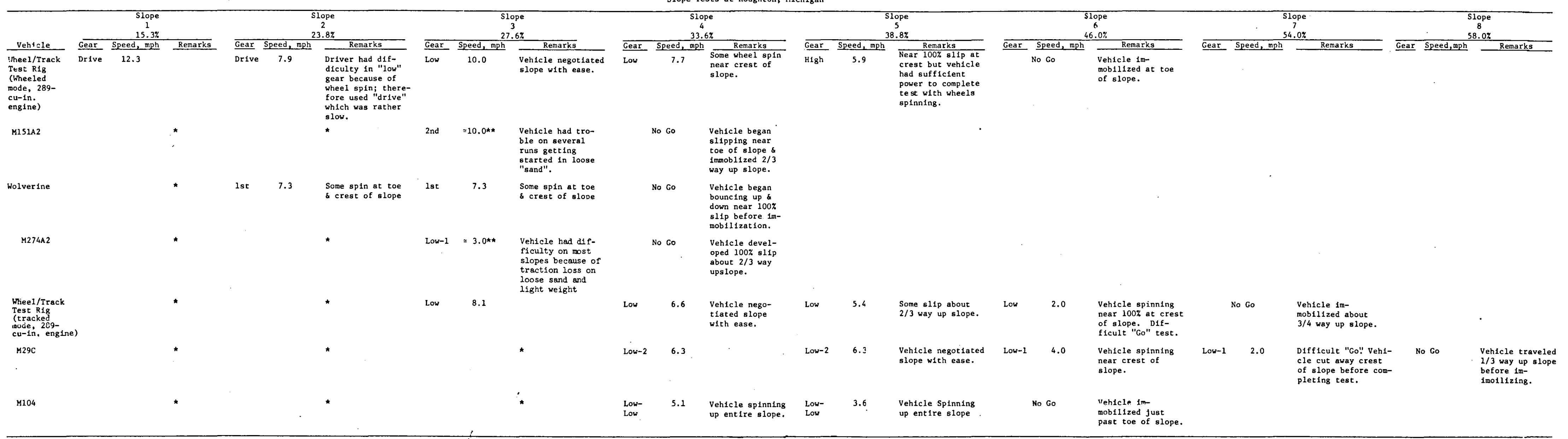

- Speeds were measured only for those slopes near the maxidum negotiable for the vehicles deternined from prel1tinary test ng.

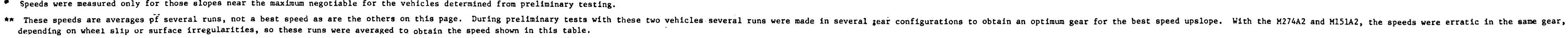

Table 10

Slope Tests at vicksburg, M1ssissippi

\begin{tabular}{|c|c|c|c|c|c|c|c|c|c|c|c|c|c|c|c|}
\hline \multirow{4}{*}{ 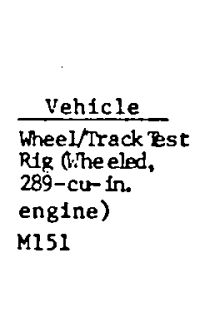 } & \multicolumn{3}{|c|}{$\frac{\text { Grassy Clay }}{-\frac{\text { Slope 1, 25\% }}{\text { Speed }}}$} & \multicolumn{3}{|c|}{$\begin{array}{c}\text { Slope 2, 35\% } \\
\text { Speed } \\
\end{array}$} & \multicolumn{9}{|c|}{$\begin{array}{c}\text { Grassy S11t } \\
\text { Slope 3, } 40.37 \\
\text { Seped. }\end{array}$} \\
\hline & Range/Cear & mph & Remarks & Range/Gear & 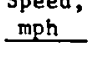 & Renarks & Range/Gear & mph & Remarks & Range/Gear & 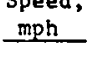 & Remarks & Range/Gear & 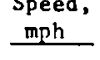 & Remarks \\
\hline & Low-2nd & 9.7 & $\begin{array}{l}\text { S1ight s1ip } \\
\text { at toe }\end{array}$ & Low-2nd & 9.0 & $\begin{array}{l}\text { Vehlcle showng } \\
\text { s118ht1y near crest }\end{array}$ & Low-2nd & 7.5 & & Low-2nd & 6.8 & & Low-1st & 6.6 & $\begin{array}{l}\text { Some bounce and } \\
\text { sitp on slope }\end{array}$ \\
\hline & $1 s t-2 n d$ & 9.3 & $\begin{array}{l}\text { Some whee } \\
\text { slip at toe } \\
\text { of slope }\end{array}$ & $1 s t-2 n d$ & 8.8 & $\begin{array}{l}\text { Vehtcle slowing } \\
\text { s11gntly near crest }\end{array}$ & 19t & 10.4 & 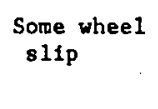 & 1st & 8.8 & 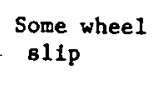 & $18 \mathrm{st}$ & 6.6 & $\begin{array}{l}\text { Whee1s silpptng } \\
\text { upper 1/2 of } \\
\text { slope }\end{array}$ \\
\hline Holver Ine & $1 s t$ & 8.8 & $\begin{array}{l}\text { Some wheel } \\
\text { sisp at at toe }\end{array}$ & 1st-2nd & 8.5 & $\begin{array}{l}\text { vehtche slowng } \\
\text { sildintly near crest }\end{array}$ & & * & & & * & & & * & \\
\hline
\end{tabular}

* The Holver ine was Inoperable because of mechanical diff tcult tes and was not repaired in tine for these tests. 
Table 11

Summary of Drawbar-Pul1 Versus S1ip Tests

Wheel/Track Convertible Test Rig

Laboratory Prepared Clay (CH) and Sand (SP)

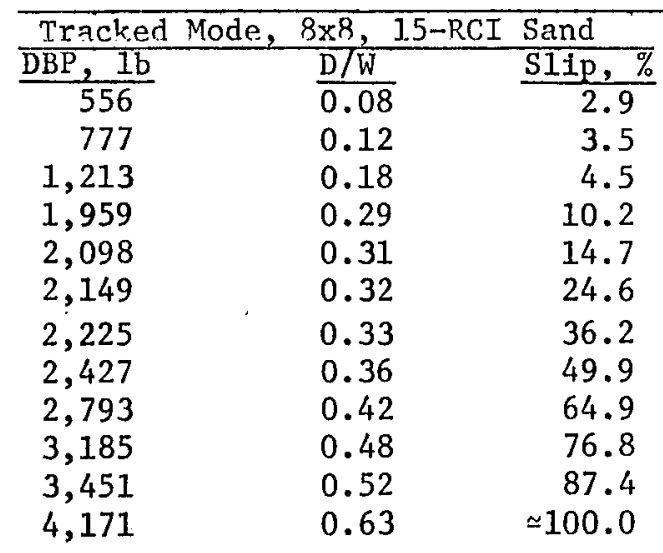

Avg towed motion resistance, $1 b=990$

\begin{tabular}{ccr} 
Tracked Mode, & \multicolumn{3}{c}{$8 \times 4$} & $15-R C I$ & Sand \\
\hline DBP, 1b & $\frac{D}{\text { D W }}$ & Slip, $\%$ \\
\cline { 2 - 3 } 700 & 0.10 & 3.8 \\
1,062 & 0.16 & 6.4 \\
1,770 & 0.27 & 8.9 \\
2,073 & 0.31 & 9.5 \\
2,402 & 0.36 & 21.4 \\
2,477 & 0.37 & 27.1 \\
2,680 & 0.40 & 37.9 \\
3,059 & 0.46 & 54.5 \\
3,198 & 0.48 & 65.7 \\
3,324 & 0.50 & 78.3 \\
3,615 & 0.54 & 87.5 \\
4,095 & 0.61 & $\approx 100.0$
\end{tabular}

Avg towed motion resistance, $1 b=784$

Tracked Mode, 8x8, 36-RCI Clay

\begin{tabular}{|c|c|c|}
\hline $\mathrm{DBP}, 1 \mathrm{~b}$ & $\mathrm{D} / \mathrm{W}$ & Slip, $\%$ \\
\hline 713 & $\overline{0.11}$ & 1.9 \\
\hline 1,278 & 0.19 & 2.7 \\
\hline 1,770 & 0.27 & 4.1 \\
\hline 2,851 & 0.43 & 6.4 \\
\hline 3,638 & 0.55 & 8.3 \\
\hline 4,105 & 0.62 & 9.8 \\
\hline 4,646 & 0.70 & 11.8 \\
\hline
\end{tabular}

Avg towed motion resistance, $1 \mathrm{~b}=1,279$

\begin{tabular}{ccr} 
Tracked Mode & $-8 \times 4$, & $36-\mathrm{RCI}$ Clay \\
\hline DBP, Ib & $\frac{\mathrm{D} / \mathrm{W}}{0.10}$ & $\frac{\text { Slip, } \%}{3.0}$ \\
\hline 635 & 0.14 & 3.4 \\
927 & 0.24 & 5.1 \\
1,574 & 0.30 & 5.9 \\
1,980 & 0.37 & 6.1 \\
2,488 & 0.48 & 6.7 \\
3,225 & 0.58 & 9.0 \\
3,885 & 0.71 & 13.0 \\
4,723 & 0.22 & 5.0 \\
1,473 & 0.38 & 6.2 \\
2,514 & 0.53 & 8.2 \\
3,529 & 0.69 & 11.5 \\
4,570 & 0.76 & 15.6 \\
5,078 & \multicolumn{3}{l}{} \\
Avg towed motion resistance, \\
1b $=896$
\end{tabular}

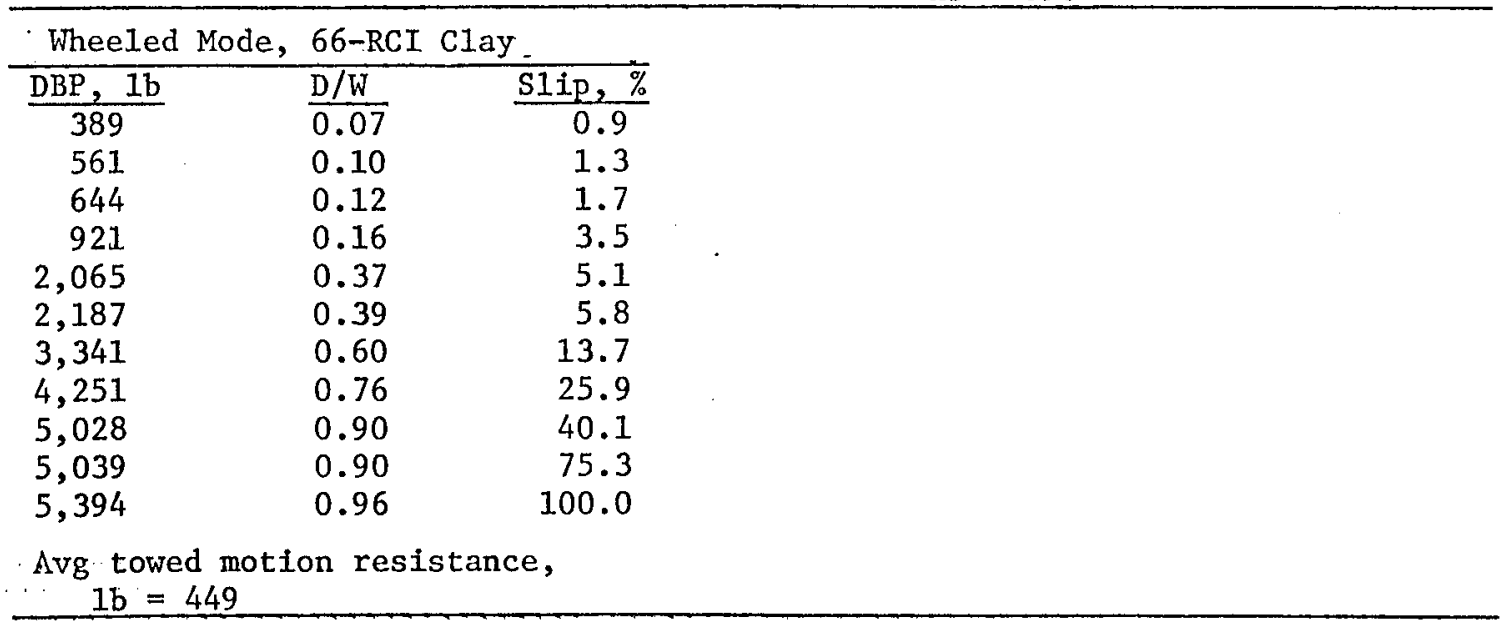


Table 12

Mobility Index Computations for Self-Propelled Wheeled Vehicles in Fine-Grained Soils

Vehicle Wheel/Track Convertible Test Rig Weight 5600

Tire Description $-6 \times 12-12$ TERRA TIRE

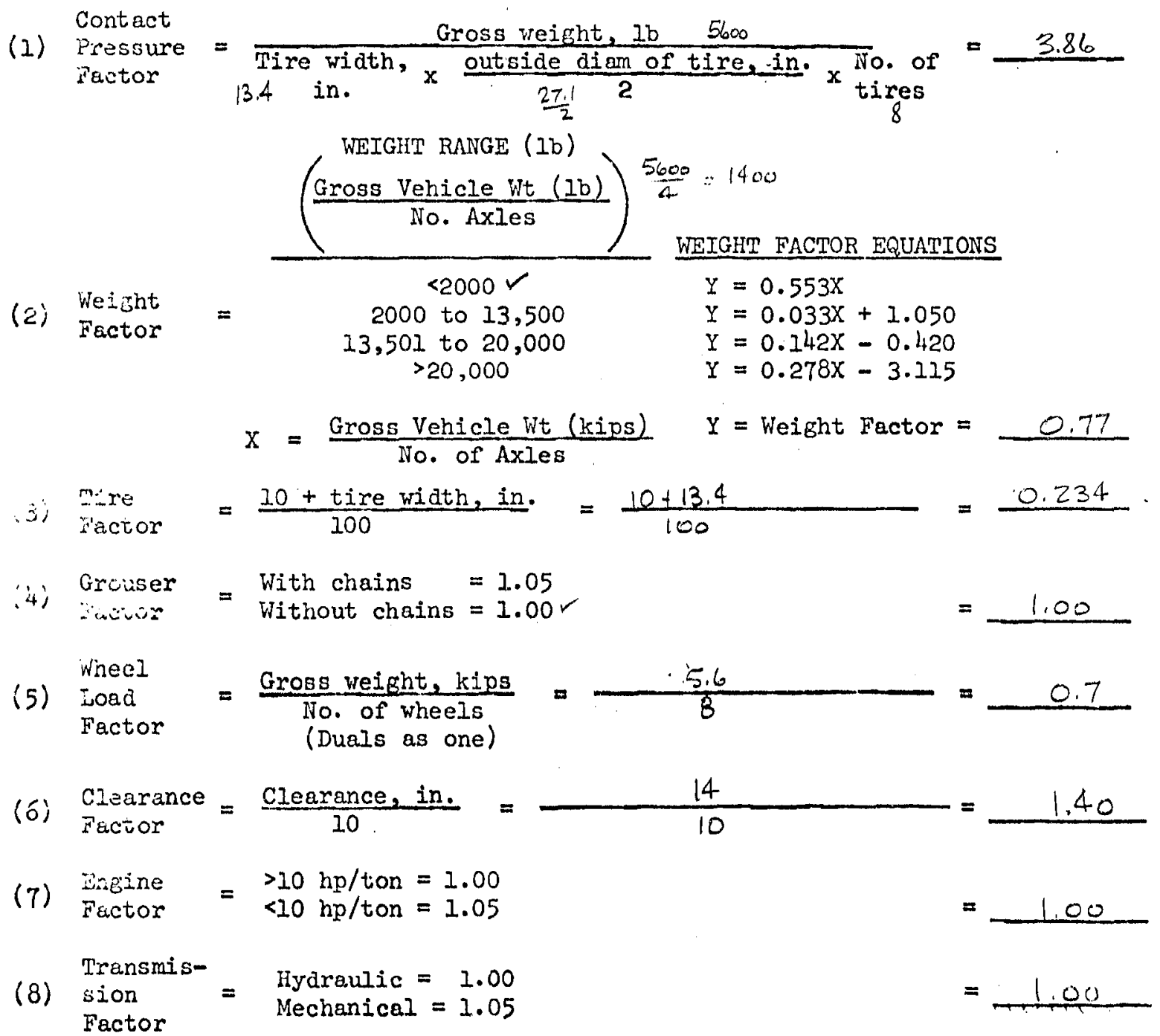

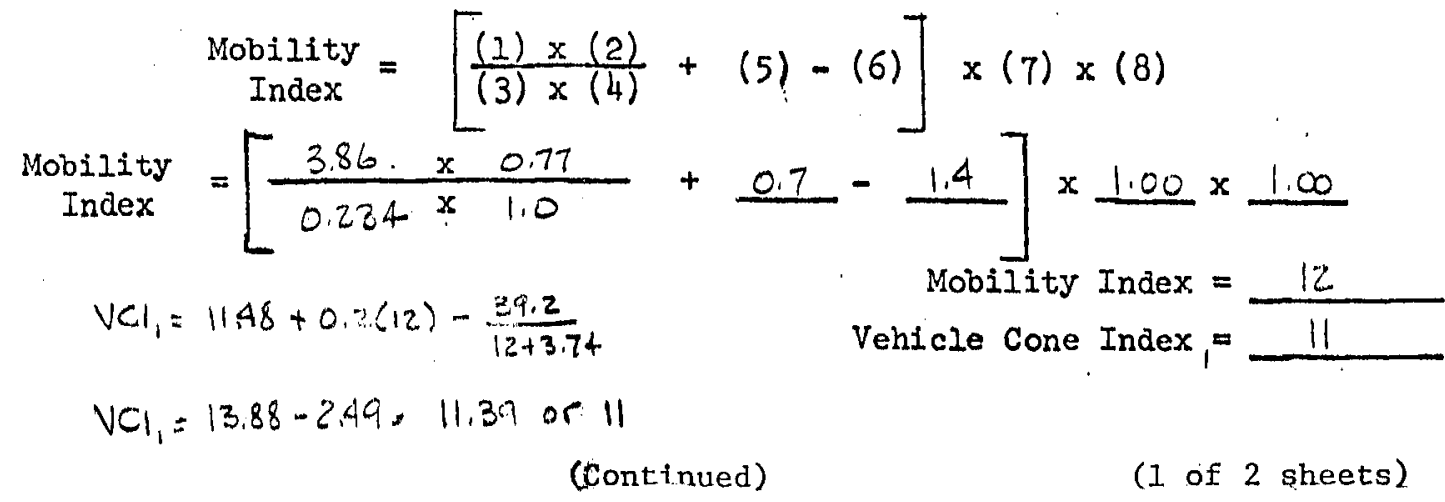


Table 12

(Concluded)

Vehicle

Wheel/Track Convertib.le Test Rig Weight 6700

Irack Description

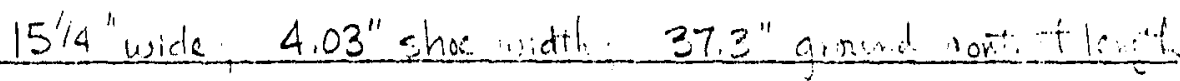
$\underset{\text { Index }}{\text { Mobility }}=\left[\frac{(1) \times(2)}{(3) \times(4)}+(5)-(6)\right] \times(7) \times(8)$

Contact

(1) Pressure

$=\frac{\text { Gross weisht, }, 1 \mathrm{~b}}{\text { Area of tracks in contact }}$

Factor with ground, sq in.

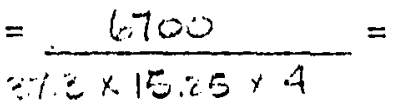
$=$

(2) Weight $\angle 50,000 \mathrm{Ib}=1.0<$

: 50,000 to $69,9991 \mathrm{~b}=1.2$ 70,000 to $99,999 \mathrm{lb}=1.4$

$=$ $100,0001 \mathrm{~b}$ or $>=1.8$

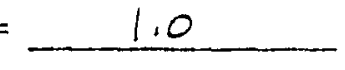

(3) Track
Factor

$=\frac{\text { Track width, in. }}{100}=$ 15.25

$=$ 0.153

(4) Grouscr

$:<1.5$ in. high $=1.0^{-}$ $>1.5 \mathrm{in} . \mathrm{high}=1.1$

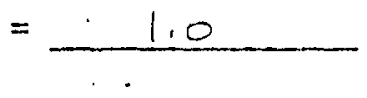

(5) Bogie Gross wt $\div 10$

Total no. bogies in contact vith ground $x$ area of 1 track shoe $=\frac{670}{8 \times 4.03 \times 15.25}$ $=$ 1,26

(6) Clearance
Factor $=\frac{\text { Clearance, in. }}{10}=$ $=$ 1.7

(7) Engine
Factor $=10 \mathrm{hp} /$ ton $=1.00$
$<1.0 \mathrm{hp} /$ ton $=1.05$. $=1.00$

Trans-

(8) mission

$$
\begin{aligned}
&= \text { Hydraulic }=1.00 \checkmark \\
& \text { Mechanical }=1.05
\end{aligned}
$$

$$
=
$$

$1, \infty$

$\left.\underset{\text { Mobility }}{\text { Index }}=\frac{2.94 \times 1.0}{.0 .153 \times 1.0}+1.36-1.7\right] \times 1.00 \times 1.00$ $=$ 18.9

$$
\begin{array}{cl}
V C I_{1}=17.0 & +0.2(18.9)-\frac{39.2}{18.9+5.6} \\
V C l_{1}=10.78-1.61 & V C 1_{1}=-9
\end{array}
$$


APPENDIX A

TEST PLAN FOR WHEEL/TRACK CONVERTIBLE

TEST RIG, 3/4-TON

\section{Background}

1. The Wheel/Track Convertible Test Rig, 3/4-Ton, is in response to USCDC Infantry Agency Draft proposed Small Development Requirement, Tactical Infantry Load Carrier/TILCAR and USARAL DPSDR, Helicopter Transportable Cargo Carrier, Full Tracked, $1 / 2$ ton (both requirements presently being rewritten in material need format). It could also be responsive to the USMC Specific Operational Requirement TM-4.5, Vehicle Utility 1/2 Ton Capacity, USAF Tactical Air Command Required Operational Capability 48-58, Improved Ground Vehicle for the Tactical Air Control System, and TVA-85 requirement for a 1/2-Ton Utility Vehicle.

2. This high mobility vehicle will provide a subsistence loadcarrying capability for the foot soldier in the forward area, thus making available the protective equipment and other items of necessity while lessening the noncombat load required to be backpacked by the infantryman.

3. The short-range objective of this program is to provide the Army with a highly mobile existence load carrier: This, in turn, will provide significant technical information for the development of the high mobility fleet projected for Army-85. The initial test rig will be a one-man $8 \times 8$ skid-steer 3/4-Ton Carrier.

\section{Status}

4. This program was initiated in FY 70, at which time the Concept Design Phase was completed. During the first quarter of FY 71, TACOM 
recismmended and received approval from $H$, AMC, to begin detailed design of a Wheel/Track Convertible Test Rig that would be based on the concept that evolved from the FY 69-70 parametric concept design phase. SubsequentIy, in FY 71, the engineering design of the major subsystems was completed. This included the hull, engine, power train and final drive, cooling system, powered road arms, and friction-driven track.

5. The Test Rig is presently being fabricated in-house by TACOM and is scheduled for completion in the third quarter FY 72. It will be powered by the Ml5I Ford LI4l four-cylinder engine, the XM50IE3 Hawk Loader automatic transmission, and a differential steer unit. Its final drive will consist of powered road arms coupled to the steer unit through a gear drive system. Testing of this configuration will be initiated in FY 72 .

\section{Objective}

6. The overall objective of the test plan is to evaluate the unique suspension and wheel/track convertible features that are considered the high risk/high return areas namely the track, suspension and handling characteristics and to determine military potential of the Test Rig. The overall objectives of the test plan are to: (a) evaluate wheel/track interface under varying surface and terrain conditions, (b) select optimum suspension characteristics, (c) determine hanaling characteristics.

\section{Scope}

7. This test plan was designed to provide sufficient quantitative performance-type data to objectively assess the feasibility of the 
wheel/track convertible concept and its unique suspension at the Exploratory Development Phase of the life cycle of the vehicle. This objective will be sought through the application of ground mobility technology developed by TACOM and WES Laboratories. Thus, specific relations that account for pertinent terrain, vehicle, driver interactions required for an objective vehicle evaluation were included in the test plan along with the appropriate data collection and analysis procedures. The type and number of tests required are minimal, and existing data for comparative vehicle performance will be utilized to the maximum in achieving the test plan objectives.

\section{Test Vehicles}

8. The test vehicles that will be used in this program are the: Wheel/Track Convertible Test Rig, 3/4-Ton; M274A2, 4x4, 1/2-Ton

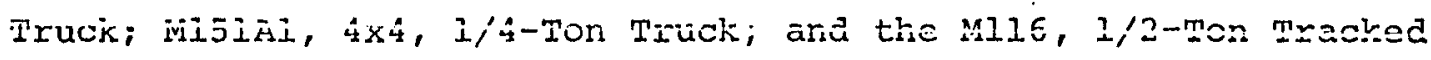
Cargo Carrier. The latter three vehicles will be used in comparative analyses when considered necessary. Special devices such as roll bars and seat belts will be adapted to the test vehicles as required to provide driver safety. A sketch of the Test Rig and pertinent characteristics are shown in fig. Al. Photographs of vehicles that will be used in comparative analyses are given in fig. A2. A comparison of Test Rig and military vehicle characteristics is shown in table Al.

\section{Test Areas}

9. Field tests will be conducted at Keweenaw Field Station, Houghton, Mich., and at Ft. Sill, Oklahoma, Vicksburg, Mississippi, and Yuma Test Station, Yuma, Arizona. Laboratory tests will be conducted at TACOM and WES. 


\section{VEHICLE CHARACTERISTICS}

INGINE

TRANSMISSION

choss onive

Buspenstom

meight Net

WElGht GROss

MAOUNDPRESSUR:

MLTATION

aANGE 25 GaL. FUEL,

mereo ranat

MORSE POWEN / TON

MEHICLE CONE INOLX

CARGO AREA

LT

IRAMSPORTABILITY
* los jeep , water cooled , gasoline Fond a spelo automatic cowie. Os so

mDEetmosmt tORSILASTIC

imotermosmt. ronsilastic

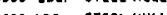

a

Q.2 psi wret - 2.7 taAck

2.6 IMEH FMEE HOARO TQ OECK

230 witrs

$0.40 \mathrm{mPH}$

34.whtec . 20 rrack

3690.11 .

1.6

Phais I ainctaft - Btackagi
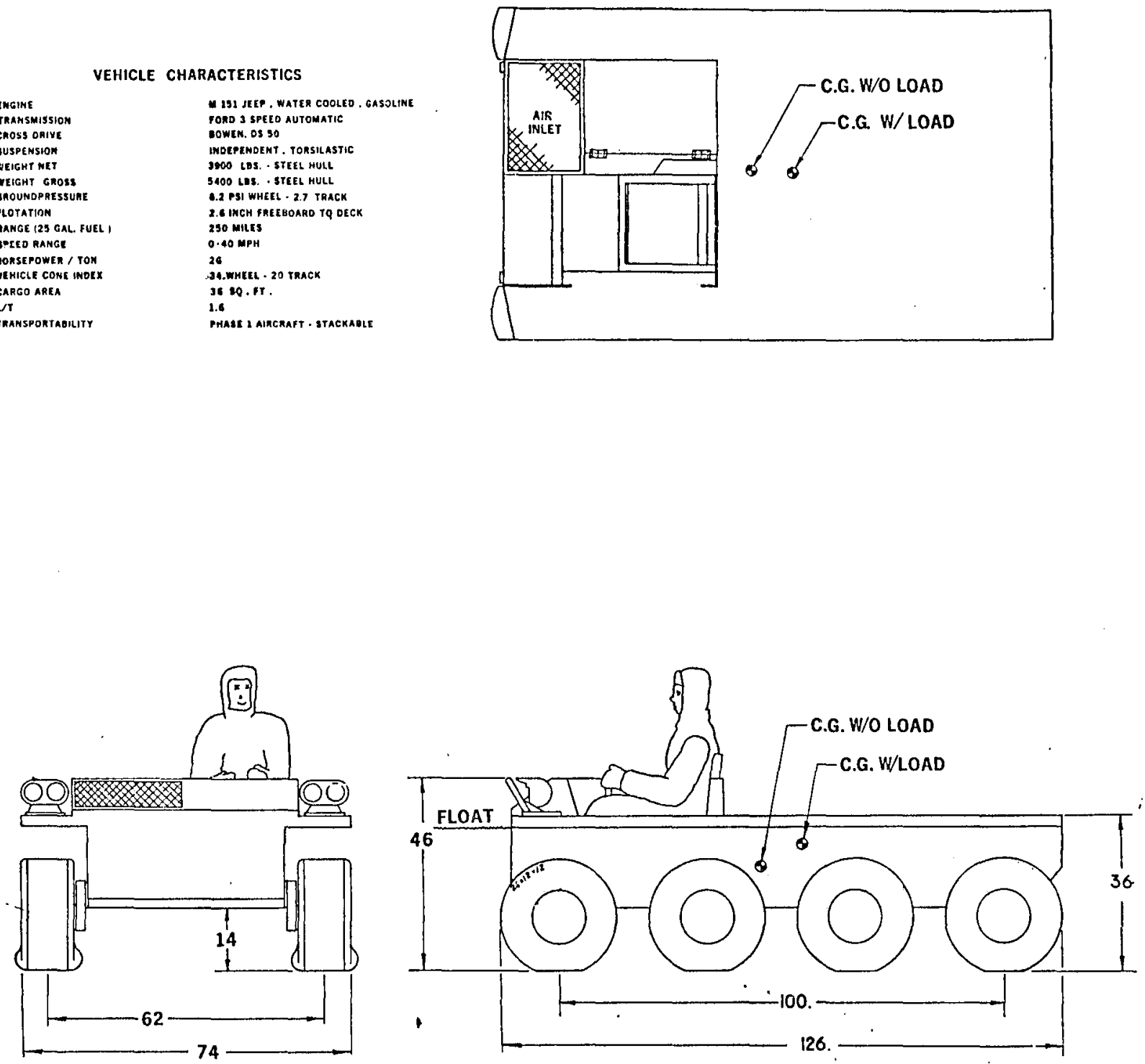

Fig. Al. Field/Track Convertible Test Rig 


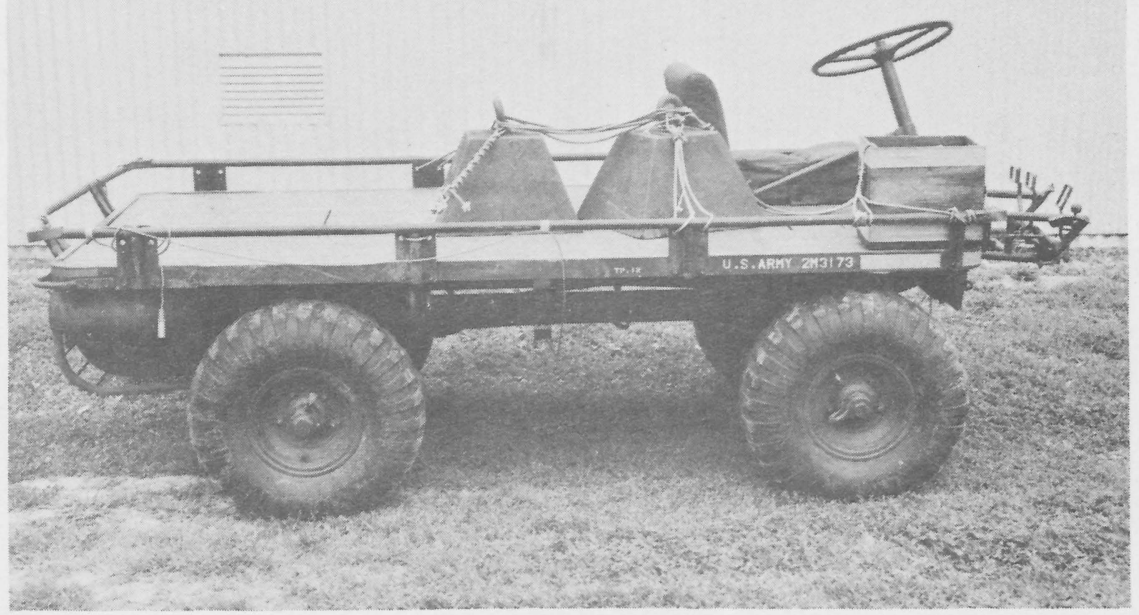

a. M274A2, 4x4, 1/2-ton truck

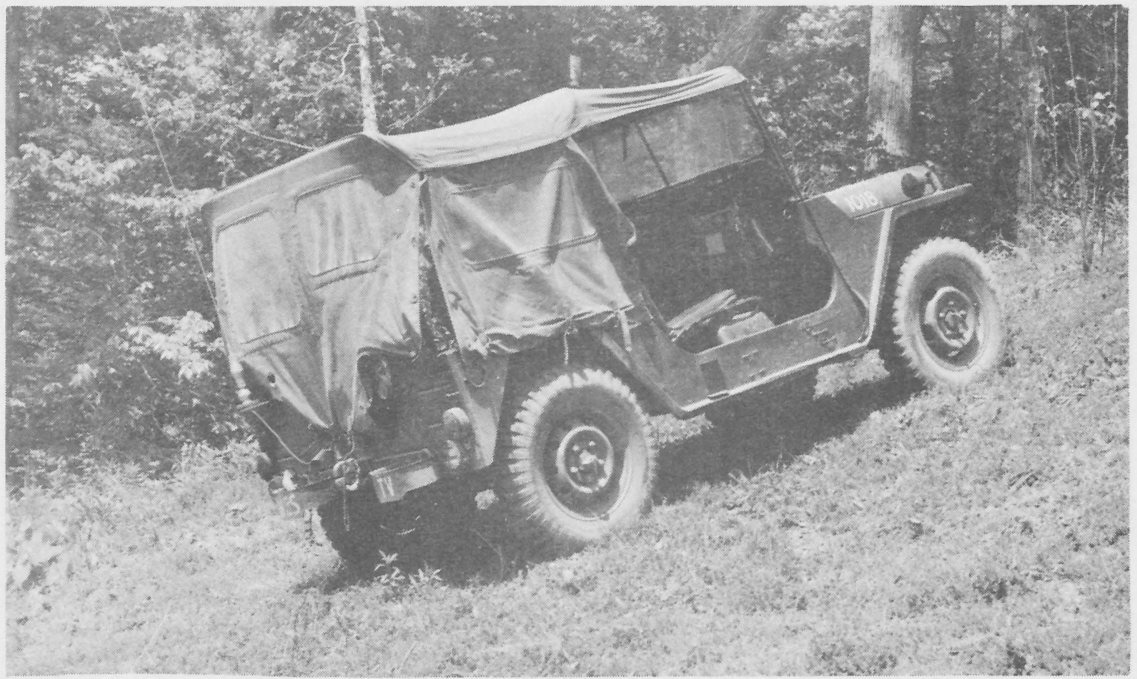

b. MI5IAI, 4x4, I/4-ton truck

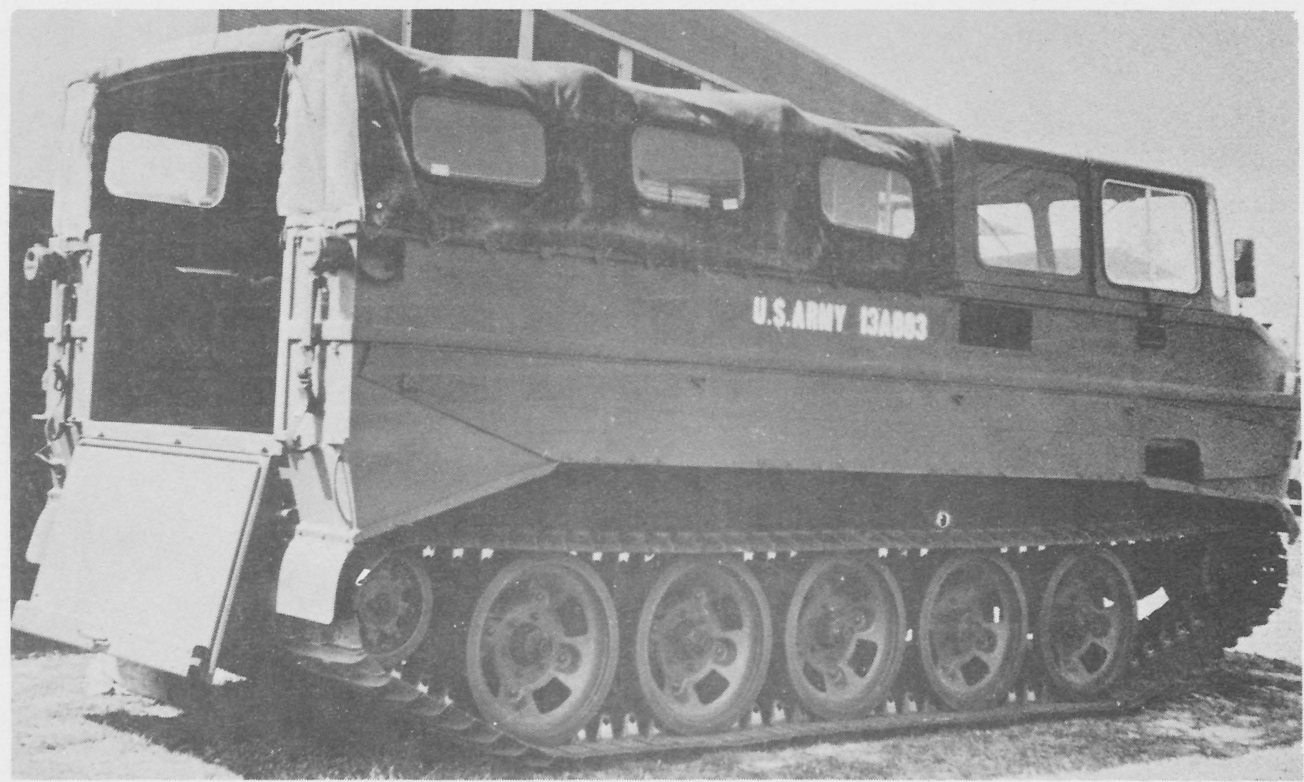

c. M116, 1-1/2-ton cargo carrier

Fig. A2. Vehicles to be used in comparative performance analysis 


\section{Test Program}

10. The test program was designed to achieve the overall objectives identified in paragraph 6 . The test activities included in the test program, listed in chronological order, are: shakedown tests, track tests, suspension tests, handling tests, and dynamic response field evaluation tests. All test activities were considered on the basis of type of test, location of test area in which the desired test condition can be found, data to be collected, results to be achieved, responsible agency, time required, and a cost estimate for each type of test.' Details of the test activities are given in tables A4, A6, A7, A8 and A9. A memorandum report will be prepared and it will include a description of the tests and a discussion of test results of all test activities.

11. In all test activities, sufficient terrain, vehicle, ariver response data will be collected to answer in quantitative terms the questions asked in each specific test activity. The terrain, vehicle, driver relations, testing techniques, and data collection procedures developed under the AMC ground mobility research programs will be used. In addition to the test activities identified herein, a daily log book will be maintained in which system failures, mileage and other data will be recorded from which conventional reliability and maintainability parameters can be obtained for comparative purposes. Photography will be used as an aid in describing terrain conditions tested and pertinent vehicle response. Measurement of fuel consumption will be made where applicable.

12. The specific test activities included in the test program are discussed in the following paragraphs. 


\section{Shakedown tests (table A4)}

13. Upon completion of Test Rig fabrication, shakedown tests will be conducted by TACOM at TACOM. The type of tests will include functional checkout, characteristic measurements, and break-in runs. The functional checkout will involve a preoperational inspection to ensure that the test vehicle is in proper functional condition for testing purposes. Physical and mechanical characteristic measurements will be made to permit making a variety of performance analyses in keeping with the AMC 71 mobility model. The specific measurements to be made are listed in table 12 . Break-in runs scheduled will further ensure the readiness of the Test Rig for field testing. The Test Rig will be run 16 hours in the wheel configuration on primary roads and 8 hours in the track configuration on secondary, unpaved roads. During these runs fund consumption rates will he determined. A summary of the test. activity, including the test variables and terrain conditions, is given in table A4. The log book documentation will be initiated with this activity and continued throughout the program. 14. The Test Rig will be provided with a simulated design payload corresponding to the average military cargo. In the track configuration, tire pressure will be varied to determine the relationship between tire pressure and track tension. Also, the ranges of track tension and tire pressures to be used in the follow-on tests will be established. During the shakedown tests, the specific wheels on which positive drive devices (sprockets) are to be installed will be determined. The results of these data will be used to prepare the Test Rig for testing operations. 
Träck tests (tablexA6)

15. These tests were designed primarily to evaluate the feasibility of the wheel/track convertible concept to determine if the track stays on, if it slips and if it causes any durability or performance problems. The tests will be conducted jointly by TACOM and WES at Houghton, Mich., and Vicksburg, Miss., upon completion of the shakedown tests. This part of the test program includes roads (primary and secondary), trail, cross-country under varying terrain conditions and special soil type tests.

16. Road and trail tests at Houghton will be the first type of test conducted. These surface media will have various combinations of slope, microgeometry, curves and surface conditions. The trails selected for testing will be described and measurements will be made according to WES techniques and the factors to be used in describing. the trails are given in the first colunn of table A5. The data also include measurement of the trail profile elevation. The Test Rig will be tested in the track and wheel configurations with the design payload. The track configuration will first be tested in friction drive, and it will also be tested in the positive drive mode (sprocket). In addition to terrain data, time and distance measurements will be made for computing average speed. Driver response will be recorded to indicate vehicle stability and handling. The sections of the trail or features on the trail that require high traction demands for the vehicle to negotiate will be selected to observe the interaction between the wheel and track especially track slippage, track throwing, soil build-up and judgement of performance. Movies of these observations will be made. Attempts will be made to maintain constant ground pressure distribution in both wheeled and tracked modes. 
17. Cross-country traverse tests will be conducted at Houghton, Mich., and these tests will provide terrain conditions not commonly found on trails. For example, tests will be conducted in woody areas where variations in stem size, spacing, macrogeometry obstacles and vertical steps such as dead fall can be found. The test variables, data to be collected, and results expected are the same as for the trail test discussed in the previous paragraph.

18. The special soil type tests were included to ensure that the performance of the Test Rig in its wheel/track configuration will be satisfactory when operating in various soft surface media since these conditions place the greatest demands on vehicle traction elements. To obtain the necessary soft snow, organic, and fine-grained soil conditions, tests will be conducted at Houghton and Vicksburg. In each of these media, uniform areas will be selected for test purposes. Fưr Ealir type ú suríace meāia, tests wili be run at three or four strengths to relate performance to strength of the media, or in case of snow, to snow depth. Vehicle operations will include straignt line (directional) and turning maneuvers in both cross-country and soft soils tests. The test variables will include wheel/track contiguration with friction and positive drives at the design payload. First-pass relations between strength and maximum drawbar pull-slip and roljing resistance will be established for fine-grained and organic soils. For snow, a relation between snow depth of finegrained, dry snow and drawbar pull-slip and rolling resistance will be developed. In fine-grained and organic soil, tests will be run at strengths ranging from above the one-pass vehicle cone 
index (minimum soil strength required) to about 50 points above the minimum requirement. Pertinent observations will be recorded, and movies will be made of the wheel/track interaction in the test media. Special attention will be given to the amount of material built up on the running gear of the vehicle.

19. Special laboratory tests will be conducted by WES with the Test Rig in the wheel/track configuration at Vicksburg in heavy clay soils prepared to the consistencies discussed in the previous paragraph and with surface conditions ranging from flooded to soft mud to determine the performance of the wheel/track convertible concept in these types of surface conditions. The test variables will be friction and positive track drives. The Test Rig will be tested at design payload and at predetermined track tensions. Drawbar pull-slip and rolling rasiztanco tcsts will be conductca to cotablish optimum track tension. For each test condition, the amount of soil build-up for various levels of traffic will be determined by weighing the vehicle before and after specific test runs. Similar tests will be run with the comparison vehicles.

20. A summary of the track tests is given in table A6, and the indoor facility to be used in the test program is shown in fig. A3.

\section{Suspension tests (table A7)}

21. Suspension tests will be conducted to optimize the Test Rig suspension system within allowable constraints. Drop and discrete obstacle tests will be conducted by TACOM at TACOM. The maximum step height that the Test Rig can negotiate will be determined using paved surface and rigid obstacles. 


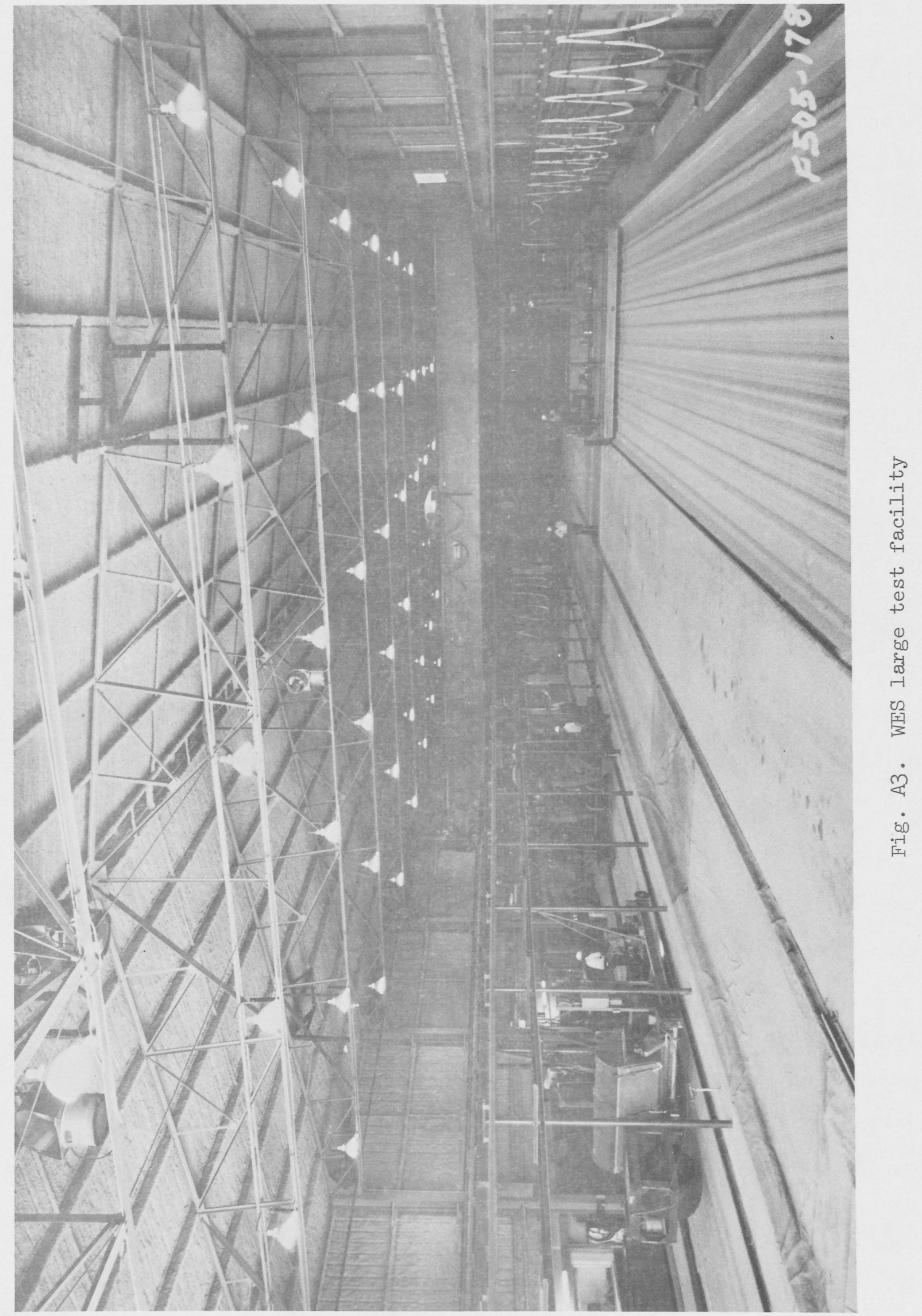


22.' In the arop tests, the Test Rig will be dropped in the track and wheel configurations. The track configuration will include the Friction and positive drive modes as previously determined in the track tests, also track tension will be constant as predetermined. All configurations will be dropped with and without payload. The variables will include tire pressure, suspension damping rate, spring rate, and wheel travel. The last three variables will be varied within allowable limits.

23. Discrete obstacle tests will be conducted to characterize the Test Rig suspension system in terms of obstacle height, speed, peak vertical acceleration relations. Tests will be run over ramped cross section, discrete, rigid obstacles fixed on a hard, level surface. Obstacle height will be varied from 2 to 12 in. Operations will be conducted at 3 -mph increments to maximum safe speed. Failure criteria. include hull pitch in excess of 20 degrees total (peak to peak) and/or peak vertical accelerations in excess of $2 \mathrm{~g}$ 's for a period in excess of 10 milliseconas. The Test Rig will be tested in the same configurations as the drop tests. In addition to the data to be collected for the arop tests, the discrete obstacle tests will include damper. temperature, vehicle speed, obstacle height, vehicle pitch and roll amplitude, vertical acceleration at CG, and vehicle pitch and roll accelerations, road arm displacements and loads. A summary of the test activity is given in table A,

Handing tests (table A 8 )

24. These tests were included in the test program to gain preliminary assessment of the dynamic stability and the handling characteristics 
of the $8 \times 8$ powered trailing arm, ratio/skid steer Test Rig in the wheel mode only. Particular emphasis will be given to the determination as to whether or not the Test Rig exhibits over/under steer characteristics when executing different rates of directional changes. These tests will be conducted by TACOM at the Raco, Michigan, airport. Test courses will be laid out on level, paved surfaces. 25. The types of tests planned include a slalom, constant radius, lane change, and sudden right angle turn. The Test Rig will be tested with and without payload, and at one tire pressure. In the slalom test, the Test Rig will be operated at several constant speeds to determine the spacing of stakes laid out in a straight line that the vehicle can maneuver around safely. Constant radius, lane change, and sudden right angle turn tests will be run at several speeds. The data to be collected will be the same for all types of tests, and they include measurements of vehicle speed, angular velocity, lateral acceleration, braking distance, driver comments and observation notes. Movie coverage will be provided during all phases of the handling tests. The results of these tests will be used to evaluate maneuverability and to determine whether or not the Test Rig exhibits dynamic instabilities. If the latter is true, a determination will be made as to the type of maneuver and speed at which these characteristics are exhibited. Similar data available for the Ml51A2 will be used in making a comparative handling evaluation. A summary of the test activity is given in table A8.

Dynamic response field evaluation test (tabie-Aá)

26. In order to gain some insight as to the dynamic response capabilities of the Test Rig over a variety of natural terrain conditions, 
cross-country and ride tests will be conducted by WES and TACOM at Ft. Sili, Yuma Proving Ground, and Vicksburg over test courses for which terrain and performance data for several vehicles (M48Al, MI13A3, MI5IA1, M35A2 mod) are available. The courses have been staked out and described recently for ground mobility purposes under other test programs. Only those terrain factors that exhibit temporal changes (e.g., soil strength) will require remeasurement. 27. Cross-country tests will be conducted with the Test Rig in track and wheel modes with the design payload. Prior testing will determine whether friction or positive drive will be used. Tests in the wheel mode will be run at one tire pressure at Ft. Sill and at two tire pressures at Yuma. Three or four courses varying in length from about 1 to 3 miles will be tested at each location. Data collection will be similar to suspension tests and will include time and distance. 28. The ride tests scheduled will be conducted by TACOM at Ft. Sill and Vicksburg with the same Test Rig variables as indicated in the above paragraph for the cross-country tests. Testing will be restricted to three level, firm, natural terrain test courses that have desired differences in root mean square (rms) elevation. At each test course, the Test Rig will be run at three or four different speeds. The data collected will be similar to that of the suspension tests. These data will be used to compute ride quality and these values will be used to compare ride with other vehicles previously tested over the same courses. A summary of test activities is given in table $A 9$. 


\section{Report}

29. A memorandum report will be prepared at the end of the test program in which the tests and the results will be described. To expedite preparation of a final report, draft reports on each test activity will be prepared as soon as completed.

\section{Test Schedule and cost}

30. A test schedule based on the number of test days and cost for each test activity is given in table Alo, and a time schedule and cost for each test activity are summarized in table All. A total of 150 working days are required and the total cost of the program is estimated at $\$ 100,000$. 
Table 1

Comparison of Test Rig and Military Vehicle Characteristics

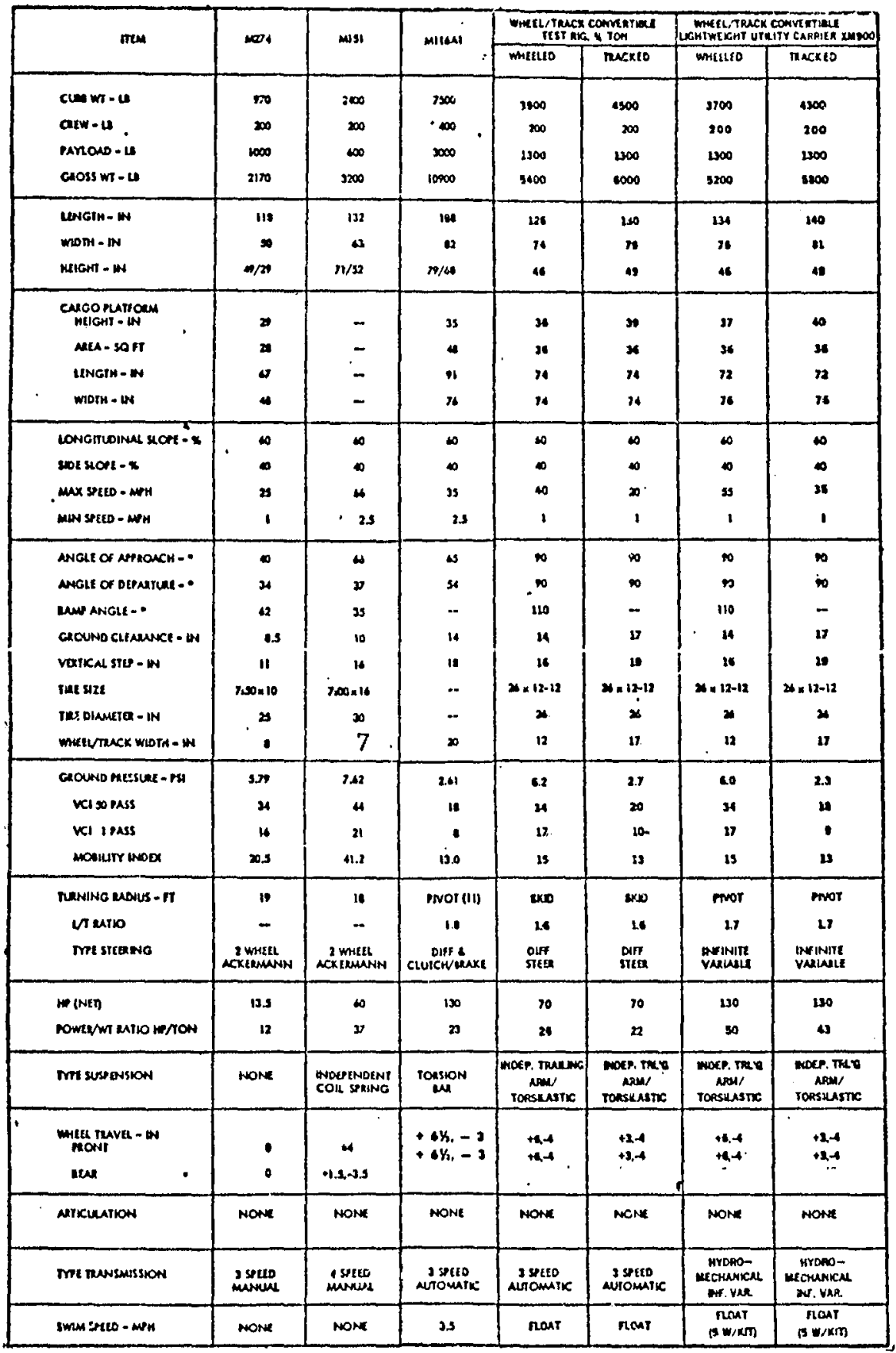


Table A2

Vehicle Data Required for AMC 71 Mobility Model

Variable

vame

NVEH

ITRAN

GViv

DI

WXD

GT

$\lambda$

HPT"

GC

MBC

ITVIR

\section{Definition}

$$
\begin{array}{r}
\text { Vehicle type } \\
\text { Tracked }=0 \\
4 \times 4=1 \\
6 \times 6=2 \\
8 \times 8=3
\end{array}
$$

Transmission type

$$
\text { stick }=0
$$

$$
\text { automatic }=1
$$

Gross vehicle weight (Ib)

Tracked: Length of track on

$$
\text { ground (in.) }
$$

Wheeled: wheel diameter (in.)

Track or wheel width (in.)

Tracked: Grouser hejght (in.)

Wheeled: Number of tires

Tracked: Area of one track

$$
\text { shoe ( } \mathrm{sq} \text {. in.) }
$$

Wheeled: Number of axles

Rated horsepower per ton

Ground clearance at the center of the greatest wheel span (in.)

Tracked: Number of bogies Wheeled: Denotes preserce

$$
\begin{aligned}
\text { of chains }- \text { no } & =0 \\
\text { yes } & =1
\end{aligned}
$$

Transmission variety

$$
\text { hydraulic }=0
$$$$
\text { mechanical }=1
$$

(1 of 8 sheets) 
Table A2 (Continued)

Variable

Name

TL

FEC

VMA

REC

VDA

CGF

CG

GWS

$\mathrm{RW}$
Definition

Distance between first and last wheel centerlines (in.)

Front end clearance (in.)

(Vertical clearance of vehicles' leading edge)

Approach angle (deg)

Rear end clearance (in.)

Departure angle (deg.)

Horizontal distance from the

CG to the front wheel centerline (in.)

Vertical. distance Irom tine

CG to the roadwheel

centerline (in.)

Maximum span between

adjacent wheel centerlines (in.)

Tracked: Roadwheel radius

plus track thickness (in.)

Wheeled: Tire rolling radius (in.) 

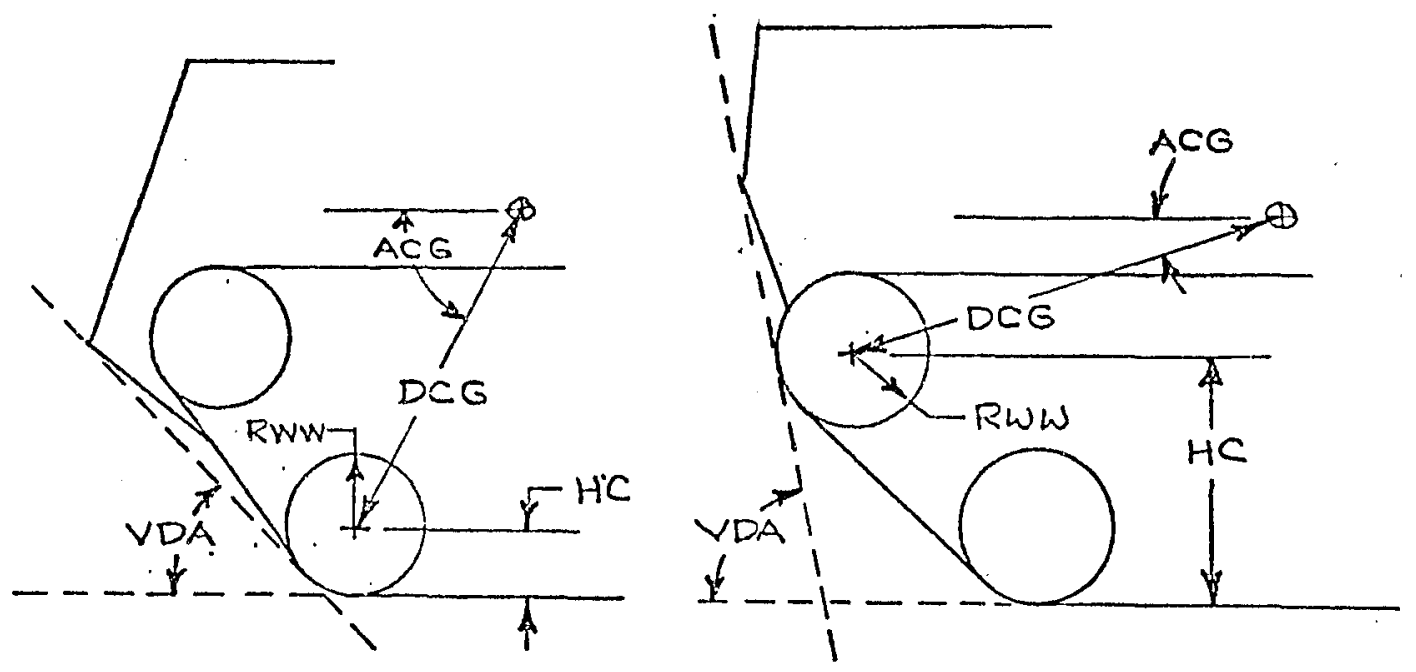

The following four variables relate to the. wheel (roadwheel or idler) whish is used to determine departure angle (see figures).

\begin{tabular}{|c|c|}
\hline I.CG & $\begin{array}{l}\text { Angle between a line } \\
\text { parallel to the ground } \\
\text { and the line connecting } \\
\text { the CG and the wheel } \\
\text { center (deg.) }\end{array}$ \\
\hline DCG & $\begin{array}{l}\text { Distance from the CG to } \\
\text { the wheel center (in.) }\end{array}$ \\
\hline $\mathrm{HC}$ & $\begin{array}{l}\text { Vertical distance from the } \\
\text { wheel center to the ground (in.). }\end{array}$ \\
\hline lKivT & $\begin{array}{l}\text { Wheel radius plus track } \\
\text { thickness (in.) }\end{array}$ \\
\hline IIs & $\begin{array}{l}\text { Maximum vertical step that } \\
\text { the vehicle can climb (in.) }\end{array}$ \\
\hline WC & Winch capacity (1b) \\
\hline SAI & Ingress swamp angle (deg.) \\
\hline
\end{tabular}

(3 of 8 sheets) 
Table A2 (Continued)

AWPK

GCA

ED

vss

VFS

NCREW

NFL

iiis $2 \dot{5}$ on $2 \ddot{y}$ :

RDIAM

TPE

TPLY

w

PBiTT

PBF

V.L

XBR

$R R$

FDK
Auxilliary water propulsion

factor (propeller, water-

jet, etc) - no $=.5$

yes $=.8$

Ground contact area (sq. in.)

Fording depth or draft height (in.)

Swimming speed (mph)

Fording speed (mph)

Number of people in the vehicle on a normal mission.

Track type - flexible $=1$

$$
\text { non - flexibje }=0
$$

Wheel rim diameter (in.)

Tire pressure (psi)

Tire ply rating

Vehicle width (in.)

pushbar height (in.)

Maximum force that the pushbar can withstand

(1b)

Vehicle length (in.)

Maximum braking force

that the vehicle can

develop (Ib)

Tracked: Sprocket pitci

radius (in.)

Wheeled: Tire rolling

radius (in.)

Final drive gear ratio 
EFF

FDREF

NG

$G R(I)$
Transmission efficiency

Final drive efficiency

Number of transmission

gear ratios

Transmission gear ratios

$V \varnothing \varnothing B(I, J)$

The velocity, in travelling over vertical obstacles, which produces, $21 / 2 \mathrm{G}$ vertical acceleration at the drivers' seat ( 5 to 20 pairs of values).

Obstacle Height (in)

Velocity

(mph) 
Table A2 (Continued)

VRIDE (I) Limiting speed due to vibration at the drivers' seat for surface roughness class $I$.

(6 watts absorbed power)

\begin{tabular}{cc}
$\begin{array}{c}\text { Roughness } \\
\text { Class }\end{array}$ & $\begin{array}{c}\text { RMS } \\
1\end{array}$ \\
\hline 2 & 0.25 \\
3 & 1. \\
4 & 2. \\
5 & 3. \\
6 & 4. \\
7 & 5. \\
8 & 6 \\
9 & 7.
\end{tabular}

Limiting

Speed (mph)

Consult the attached graph to approximate these values. If more accuracy is -required, the absorbed power calculation has been programmed and is available. 
Table A2 (Continued)

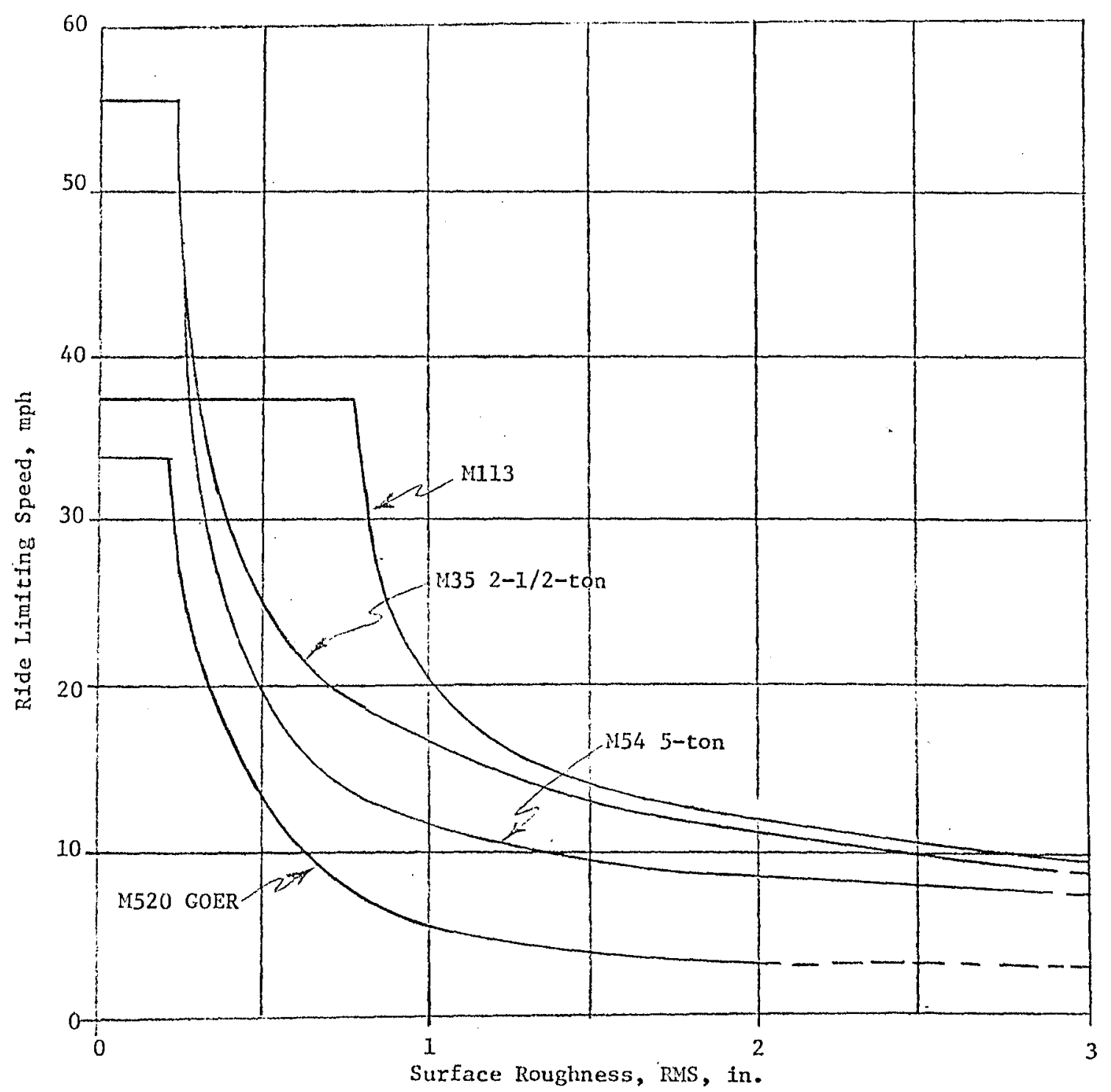

RIDE DYNAMICS CHARACTERISTICS $\mathrm{OF}$

FOUR MILITARY VEHICLES

NOTE: Curves based on existing data (7 Nov 73)

(7 of 8 sheets) 
TTE $[, J)$ Net engine thrque versus engine speed curve. (10 to 20 pail:i of valves). Include maximum and minimum m.mine speed.

Engine Speed (RPM)

Net Engine Torque (ft. 1b.)

The ollowing are required for a vehicle with a torque converter.

TC

Input torque at which the torqueconverter curves were measured (ft. Ib.)

ENTCG

Gear ratio between engine and torque-converter (if present)

LøKUP Denotes presence of a torqueconverter lock-up.

$$
\begin{aligned}
& \text { no }=0 \\
& \text { yes }=1
\end{aligned}
$$

$\operatorname{TNE} I(I, J)$

Converter input speed versus

speed ratio curve. ( 10 to 20

pairs of values)

Speed Ratio

Input Speed (RPM)

Tim,,$- J)$ Converter torque multiplying coefficient versus speed ratio curve (10 to 20 pairs of values)

Speed Ratio

Torque Multiplying

Coefficient

( 8 of 8 sheets) 
Legend for Test Variables Given in Table A4 and Tables :A6-A9

\section{Description}

Funning gear configuration - wheeled

Running gear configuration - tracked

Vehicle weight (loaded or unloaded)

Suspension damping rate

Suspension spring rate

Suspension wheel travel

Track tersion

Friction drive between wheel and track

Positive drive (sprocket) between wheel and track

Vehicle unloaded

Vehicle loaded

Tiro prossyre

Ground contact pressure

Vehicle speed

Obstacle height
Dimension

Symbol

$$
\text { NA }
$$

NA

Ib

Ib sec/ft

Ib/ft

in.

Ib

NA

NA

NA

NA

psi

psi

$\mathrm{mph}$

in. w

$t$

W

c

k

z

$\mathrm{T}$

$t_{f}$

$t p$

u

1

$T_{F}$

$\mathrm{p}$

$\mathrm{v}$

o 
Table A4

\section{Shakedown Tests}

\begin{tabular}{|c|c|c|c|c|c|c|c|}
\hline Type of Test & Location & $\begin{array}{l}\text { Test Variables } \\
\text { and/or } \\
\text { Test Conditions* }\end{array}$ & $\begin{array}{l}\text { Data to be } \\
\text { Collected }\end{array}$ & Results & $\begin{array}{l}\text { Respon- } \\
\text { sible } \\
\text { Agency }\end{array}$ & $\begin{array}{c}\text { Schedule } \\
\text { (Work Days) } \\
\end{array}$ & $\begin{array}{c}\text { Cost } \\
\text { (New } \\
\text { Money) } \\
\end{array}$ \\
\hline $\begin{array}{l}\text { Functional } \\
\text { Checkout }\end{array}$ & TACOM & NA & Record of adjustments & Log of adjustments & TACOM & $1-2$ & $0 * *$ \\
\hline $\begin{array}{l}\text { Characteristic } \\
\text { Measurements }\end{array}$ & TACOM & $\begin{array}{l}t, w, p, w, c, \\
k, z, T, u, I\end{array}$ & Physical, mechanical & $\begin{array}{l}\text { Establish relations } \\
\text { pertinent to dynamic } \\
\text { vehicle response and } \\
t / w \text { interface frictio }\end{array}$ & $\begin{array}{l}\text { TACOM } \\
\text { on }\end{array}$ & $3-6$ & 0 \\
\hline Break-in Runs & TACOM & $\begin{array}{l}\mathrm{w}-16 \mathrm{hr} \\
\mathrm{t}-8 \mathrm{hr}\end{array}$ & $\begin{array}{l}\text { Observation nutes. } \\
\text { Record of adjustments } \\
\text { and fuel consimption. }\end{array}$ & $\begin{array}{l}\text { Summary of notes, } \\
\text { fuel consumption rate }\end{array}$ & $\mathrm{e}^{\mathrm{TACOM}}$ & $7-10$ & 0 \\
\hline
\end{tabular}

* See table A3. For iegend.

* Previously authorized funds to be used. 
Tobse 5

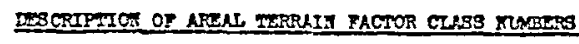

\begin{tabular}{|c|c|c|c|c|c|c|c|c|c|c|c|c|c|c|}
\hline \multirow[b]{2}{*}{ ERRRAIM PACTORS } & \multicolumn{14}{|c|}{ Class kivibers } \\
\hline & 1 & 2 & 3 & 4 & 5 & 6 & 7 & 8 & 9 & 10 & 11 & 12 & 13 & 24 \\
\hline SURPACE TYPE & $\begin{array}{c}\text { Pre } \\
\text { Grafred } \\
\text { Sot }\end{array}$ & $\begin{array}{l}\text { Coerse } \\
\text { Gretned }\end{array}$ & Muskeg & Nest & Perzaneat & & & & 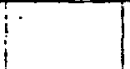 & & & \multicolumn{3}{|c|}{ Spovs } \\
\hline $\begin{array}{l}\text { - SLRPACE STPETGTH (CI OF RET) } \\
\text { CIASS RAIGE }\end{array}$ & $>280$ & $221-280$ & $161-220$ & $101-160$ & $61-100$ & $41-60$ & $33-40$ & $26-32$ & $37-25$ & $21-16$ & $0-10$ & $23-25$ & $7-12$ & $0-6$ \\
\hline VRLUE SELSCTES YOR PREOICTIC & $>300$ & 250 & 190 & 130 & 80 & 50 & 35 & 29 & 20 & 14 & 5 & 19 & 10 & 3 \\
\hline SLOPR(II) & $>0-2$ & $2.1-5$ & $5.1-10$ & $10.1-20$ & $20.1-40$ & $40.1-60$ & $60.1-70$ & $>70$ & & & & & & \\
\hline - VALUE SEIECTED POR PREDICTIOX & $>$ : & 3.5 & 7.5 & 15.0 & 30.0 & 50.0 & 65.0 & 72.0 & & & & & & \\
\hline $\begin{array}{l}\text { CBSTACIE APPROAGI RRGLE (Dez.) } \\
\text { CLASS RAME }\end{array}$ & $178.6-180$ & $180-181.5$ & $|175.6-178.5|$ & $181.5-184.5$ & $170.1-275.5$ & $184,5-190$ & $158.1-170$ & $190.1-202$ & $249.1-158$ & $202.2-211$ & $\mid 135.1-169$ & $211.1-225$ & s0.0-135 & $226-270$ \\
\hline TALUE SRIECTED POR PEEDICTIO & 179 & 181 & $1 \pi 7$ & 183 & 173 & 187 & 164 & 196 & 154 & 205 & 142 & 218 & 112 & 248 \\
\hline 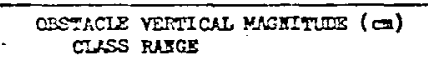 & $0-15$ & $16-25$ & $26-35$ & $35-45$ & $46-60$ & $60-85$ & $>85$ & & & & & & & \\
\hline VALUT SEIECTED FCR FREDICTIO & 8 & 20 & 30 & 40 & 52 & 72 & 85 & & & & & & & \\
\hline $\begin{array}{l}\text { OBSTRCLE BASE YIDTH (O) } \\
\text { CUSS RAYGE }\end{array}$ & $>120$ & $91-120$ & $61-90$ & $31-60$ & $0-30$ & & & & & & & & & \\
\hline TALTES SEIICERD POR PFEDICTIOA & 360 & 205 & 75 & 45 & 15 & & & & & & & & & \\
\hline $\begin{array}{l}\text { CESTACIS IRTGTI (n) } \\
\text { CIASS RATGP }\end{array}$ & $0 . .3$ & $.4-1.0$ & $1.1-2.0$ & $2.1-3.0$ & $3.2-6.0$ & $6.1-150$ & $>150$ & & & & & & & \\
\hline VALUS SPIECTED FOR FREDICTIOS & .2 & .6 & 1.5 & 2.5 & 4.5 & 78 & 150 & & & & & & & \\
\hline $\begin{array}{l}\text { CESTICIE STACISG (n) } \\
\text { CULSS RAEGT }\end{array}$ & Bare & $20.1-60$ & i. 1-20 & $8.2-12$ & $5.6-8$ & $2.1-5.5$ & $2.6-4.0$ & 0.2 .5 & & & & & & \\
\hline PRULZ SEIZCTED FOB PREDICTIC & 60 & to & 15.5 & 9.5 & 6.8 & 4.8 & 3.3 & 1.2 & & & & & & \\
\hline COSTACZY SPACTES ITPY. & Rendico & Lnear & & & & & & & & & & & & \\
\hline 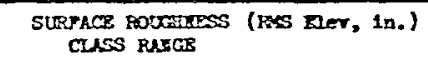 & $0 . .6$ & $.5-1.5$ & $1.6-2.5$ & $2.6-3.5$ & $3.6-4.5$ & $4.6-5.5$ & $5.6-5.5$ & $6.6-7.5$ & $>7.6$ & & & & & \\
\hline vAUUR SEIECTXD FOR PRROICTIOS & .2 & $i$ & 2 & 3 & 4 & 5 & 6 & 1 & $B$ & & & & & \\
\hline STM DIAMETXI (a) & 0 & $>2.5$ & 26.0 & $>10$ & 224 & $>18$ & $>22$ & $>25$ & & & & & & \\
\hline PACEOR VRUAR & o. & 3 & 6 & 10 & $1 k$ & 18 & 22 & 25 & & & & & & \\
\hline $\begin{array}{l}\text { STEX SPACIFG (x) } \\
\text { CIASS RATRS }\end{array}$ & Bare & 220 & $11.1-20$ & $8.1-11$ & $5.6-8$ & $p^{4.1-5.5}$ & $2.6-4$ & $0-2.5$ & & & & & & \\
\hline VAUUE SRIZCESD FOR PREDICTIOA & 100 & 20 & 15.5 & 9.5 & 6.8 & 4.8 & 3.3 & 1.2 & & & & & & \\
\hline VISIEILIT (m) & $>50$ & $24.2-50$ & $12.1-24$ & $9.1-12$ & $6.1-9$ & $4.6-6$ & $3.2-4.5$ & $2.6-3.0$ & $0-1.5$ & & & & & \\
\hline VALUE SELECTRD POR PPEOICTIOU & 50 & 37 & 18 & 10.6 & 7.5 & 5.3 & 3.8 & 2.3 & .8 & & & & & \\
\hline 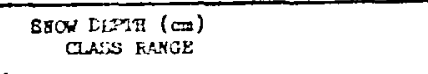 & $2.5-30.5$ & $30.6-45.7$ & $45.8-61.0:$ & $61.1-76.2$ & $76.3-91.4$ & $\begin{array}{l}91.5- \\
121.9\end{array}$ & $\begin{array}{l}122.0- \\
152.5\end{array}$ & $\begin{array}{l}152.6- \\
182.9\end{array}$ & $>182.9$ & & & & & \\
\hline 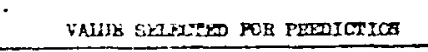 & 26.5 & 33.2 & $=53.4$ & 68.6 & 83.8 & 106.7 & 137.2 & 167.8 & 182.9 & & & & & \\
\hline SWY WHETUFE CANDITICA & $\mathrm{Dry}$ & Wet. & & & & & & & & & & & & \\
\hline
\end{tabular}


Table A6

Track Tests

\begin{tabular}{|c|c|c|c|c|c|c|c|}
\hline Type of Test & Location & $\begin{array}{l}\text { Test Variables } \\
\text { and/or } \\
\text { Test Conditions* }\end{array}$ & $\begin{array}{l}\text { Data to be } \\
\text { Collected }\end{array}$ & Results & $\begin{array}{l}\text { Respon- } \\
\text { sible } \\
\text { Agency }\end{array}$ & Schedule & $\frac{\text { Cost }}{\text { TACOM/WES }}$ \\
\hline Trail & Houghton & $\begin{array}{l}\text { Trails having } \\
\text { various combina- } \\
\text { tions of slope, } \\
\text { microgeometry, } \\
\text { and surface con- } \\
\text { ditions } \\
t_{f}, t_{p}, w, 1, v\end{array}$ & $\begin{array}{l}\text { Average speed, ob- } \\
\text { servation notes, } \\
\text { terrain factors, } \\
\text { driver comments }\end{array}$ & $\begin{array}{l}\text { Comparative speed } \\
\text { performance eval- } \\
\text { uation }\end{array}$ & $\begin{array}{l}\text { TACOM } \\
\text { and } \\
\text { WES }\end{array}$ & $11-24$ & $\$ 10000 / \$ 5000$ \\
\hline $\begin{array}{l}\text { Cross-country } \\
\text { traverse }\end{array}$ & Houghton & $\begin{array}{l}\text { Same as trail-- } \\
\text { with additional } \\
\text { terrain variam } \\
\text { tion }\end{array}$ & Same as trail & Same as trail & $\begin{array}{l}\text { TACOM } \\
\text { and } \\
\text { WES }\end{array}$ & $25-37$ & $\$ 7000 / \$ 3000$ \\
\hline \multirow[t]{2}{*}{$\begin{array}{l}\text { Special ter- } \\
\text { rain condi- } \\
\text { tions }\end{array}$} & $\begin{array}{l}\text { Houghton } \\
\text { and } \\
\text { Vicksburg }\end{array}$ & $\begin{array}{l}\text { Snow, organic } \\
\text { soil, fine- } \\
\text { grained soil } \\
t_{f}, t_{\dot{p}}, 1\end{array}$ & $\begin{array}{l}\text { Observation of } w / t \\
\text { interaction, max } \\
\text { DB?, motion resis- } \\
\text { tarce, type and } \\
\text { strength of sur- } \\
\text { face media }\end{array}$ & $\begin{array}{l}\text { Establish perti- } \\
\text { nent relations } \\
\text { such as surface } \\
\text { media strength- } \\
\text { DBP-motion } \\
\text { resistance re- } \\
\text { lations }\end{array}$ & $\begin{array}{l}\text { TACOM } \\
\text { and } \\
\text { WES }\end{array}$ & $38-56$ & $\$ 10000 / \$ 15000$ \\
\hline & & & & & Totals & 46 days & $\$ 50,000$ \\
\hline
\end{tabular}

* See table A3 for legend. 
Suspens:ion Tests.

\begin{tabular}{|c|c|c|c|c|c|c|c|}
\hline Type of Test & Location & $\begin{array}{l}\text { Test Variables } \\
\text { and/or } \\
\text { Test Conditions* }\end{array}$ & $\begin{array}{l}\text { Data to be } \\
\text { Collected }\end{array}$ & Results & $\begin{array}{l}\text { Respon- } \\
\text { sible } \\
\text { Agency }\end{array}$ & Schedule & Cost \\
\hline Drop & TACOM & $\begin{array}{l}t, w, u, l, T_{p}, \\
t_{f}, t_{p}, \text { vary } c, \\
k, z \text { within } \\
\text { allowable limits; } \\
\text { vehicle dropped } \\
\text { on firm, level } \\
\text { surface }\end{array}$ & $\begin{array}{l}\text { Road arm load and posi- } \\
\text { tion at stat:on } 1,2 \text {, } \\
\text { and } 4 \text { on lefi, side of } \\
\text { vehicle, frequency and } \\
\text { damping of vehicle os- } \\
\text { cillation, spring damp- } \\
\text { ing rate of compliance } \\
\text { elements, anc. observa- } \\
\text { tion notes }\end{array}$ & $\begin{array}{l}\text { Establish vehicle } \\
\text { dynamic characteris- } \\
\text { tics from frequency } \\
\text { and damping of vehi- } \\
\text { cle oscillation and } \\
\text { spring and damping } \\
\text { rates of compliance } \\
\text { elements within } \\
\text { allowable constraints. } \\
\text { Tune dynamic mathe- } \\
\text { matical simulation } \\
\text { model. }\end{array}$ & TACOM & $57-87$ & $\$ 12,000$ \\
\hline $\begin{array}{l}\text { Discrete } \\
\text { Obstacles }\end{array}$ & TACOM & $\begin{array}{l}t, w, t_{f}, t_{p}, u, \\
l, 0, v, T_{p} ; \text { vary } \\
c, k, z \text { within } \\
\text { allowable limits; } \\
\text { rigid, ramped } \\
\text { cross-section } \\
\text { obstacles placed } \\
\text { on level, firm } \\
\text { surface }\end{array}$ & $\begin{array}{l}\text { In addition to drop } \\
\text { test data, demper tem- } \\
\text { peratures, vehicle speed } \\
\text { obstacle height, vehicle } \\
\text { pitch and roll amplitudes, } \\
\text { vertical acceleration at } \\
\text { CG, vehicle fitch and roll } \\
\text { acceleration as well as } \\
\text { suspension displacement } \\
\text { and load will be measured } \\
\text { Driver comments will be } \\
\text { recorded. }\end{array}$ & $\begin{array}{l}\text { Establish obstacle } \\
\text { height, speed, ver- } \\
\text { tical acceleration } \\
\text { relations. Compare } \\
\text {, dynamic performance } \\
\text { with other vehicles } \\
\text { a. To }\end{array}$ & $\begin{array}{l}\text { TACON } \\
- \\
3\end{array}$ & 42 days & $\$ 20,000$ \\
\hline
\end{tabular}


Tazle Å

Handling Tests

\begin{tabular}{|c|c|c|c|c|c|c|c|}
\hline Type of Test & Location & $\begin{array}{l}\text { Test Variables } \\
\text { and/or } \\
\text { Test Conditions* }\end{array}$ & $\begin{array}{l}\text { Data to be } \\
\text { Collectec }\end{array}$ & Results & $\begin{array}{l}\text { Respon- } \\
\text { sible } \\
\text { Agency }\end{array}$ & Schedule & Cost \\
\hline Slalom & $\begin{array}{l}\text { Raco, } \\
\text { Mich. }\end{array}$ & $\begin{array}{l}w, u, l, v, \\
\text { Paved runway }\end{array}$ & $\begin{array}{l}\text { Speed, angulir velocity, } \\
\text { lateral acceleration, } \\
\text { driver commerts, ob- } \\
\text { servation notes }\end{array}$ & $\begin{array}{l}\text { Evaluation of han- } \\
\text { dling characteris- } \\
\text { tics }\end{array}$ & TACON & $99-100$ & s.1000 \\
\hline $\begin{array}{l}\text { Constent } \\
\text { Radius }\end{array}$ & $\begin{array}{l}\text { Raco, } \\
\text { Mich. }\end{array}$ & $\begin{array}{l}\mathrm{w}, \mathrm{u}, I, \mathrm{~T}_{\mathrm{p}}, \mathrm{v} \\
\text { Paved runway }\end{array}$ & Same as slalom test & $\begin{array}{l}\text { Establish over/under } \\
\text { steer characteristics }\end{array}$ & TACOM & $101-103$ & $\$ 1500$ \\
\hline Lane Change & $\begin{array}{l}\text { Raco, } \\
\text { Mich. }\end{array}$ & $\begin{array}{l}\text { w, u, I, v } \\
\text { Paved runway }\end{array}$ & Same as slalcm test & $\begin{array}{l}\text { Establish if over/ } \\
\text { under steer is crit- } \\
\text { ical from handling } \\
\text { standpoint }\end{array}$ & TACOM & $104-106$ & $\$ 1500$ \\
\hline \multirow[t]{2}{*}{$\begin{array}{l}\text { Sudden Right } \\
\text { Angle Turn }\end{array}$} & $\begin{array}{l}\text { Raco, } \\
\text { Mich. }\end{array}$ & $\begin{array}{l}\text { w, u, } 1, v \\
\text { Paved. runway }\end{array}$ & Same as slalom test & Same as lane change & TACOM & $107-108$ & $\$ 1000$ \\
\hline & & & & & Totals & 10 days & $\$ \$ \$, 000$ \\
\hline
\end{tabular}


Talle A9

\section{Dynamic Response Field Evaluation Tests}

\begin{tabular}{|c|c|c|c|c|c|c|c|}
\hline Type of Test & Location & $\begin{array}{l}\text { Test Variables } \\
\text { and/or } \\
\text { Test Conditions* }\end{array}$ & $\begin{array}{l}\text { Data to be } \\
\text { Collected }\end{array}$ & Results & $\begin{array}{l}\text { Respon- } \\
\text { sible } \\
\text { Agency }\end{array}$ & Schedule & Cost \\
\hline $\begin{array}{l}\text { Cross-country } \\
\text { Traverse }\end{array}$ & $\begin{array}{l}\text { Ft. Sill, } \\
\text { Yuma } \\
\text { Proving } \\
\text { Ground }\end{array}$ & $\begin{array}{l}t, w, t_{f}, t_{p} \\
\text { several traverses } \\
\text { containing a vari- } \\
\text { ety of terrain } \\
\text { conditions }\end{array}$ & $\begin{array}{l}\text { Average speed, terrain } \\
\text { factors, observation } \\
\text { notes, driver comments }\end{array}$ & $\begin{array}{l}\text { Comparative speed } \\
\text { performance with } \\
\text { several vehicles }\end{array}$ & WES & $109-118$ & $\$ 10000$ \\
\hline \multirow[t]{2}{*}{ Ride } & $\begin{array}{l}\text { Ft. Sill, } \\
\text { Vicksburg }\end{array}$ & $\begin{array}{l}t, w, I, t_{f}, t_{p} \\
\text { three firm courses } \\
\text { varying in rms } \\
\text { elevation }\end{array}$ & $\begin{array}{l}\text { Speed, vert:cal accel- } \\
\text { eration at selected } \\
\text { points on vehicle, } \\
\text { terrain fac;ors, } \\
\text { observation notes, } \\
\text { driver comments }\end{array}$ & $\begin{array}{l}\text { Comparative ride } \\
\text { performance with } \\
\text { several vehicles }\end{array}$ & TACOM & $119-128$ & $\$ 10000$ \\
\hline & & & & & Totels & $\overline{20 \text { days }}$ & $\$ 20,000$ \\
\hline
\end{tabular}

* See table A 3 for legeñd. 
Table A10

Test Schedule and Costs

\begin{tabular}{|c|c|c|c|c|c|c|}
\hline \multirow[b]{2}{*}{ Test Activity } & \multicolumn{2}{|c|}{ Time, Workdavs } & \multicolumn{3}{|c|}{ Costs $(\$ 1000)$} & \multirow{2}{*}{$\begin{array}{l}\text { Accumulative } \\
\text { Total }\end{array}$} \\
\hline & & $\begin{array}{l}\text { Accumu- } \\
\text { lative }\end{array}$ & TACOM & WES & Total & \\
\hline 1. Shakedown tests & & & & & & \\
\hline $\begin{array}{l}\text { Functional checkout } \\
\text { Characteristic measurements } \\
\text { Break-in runs }\end{array}$ & $\begin{array}{l}2 \\
4 \\
4\end{array}$ & $\begin{array}{r}2 \\
6 \\
10\end{array}$ & $\begin{array}{l}0 \\
0 \\
0\end{array}$ & $\begin{array}{l}0 \\
0 \\
0\end{array}$ & $\begin{array}{l}0 \\
0 \\
0\end{array}$ & \\
\hline
\end{tabular}

2. Track tests

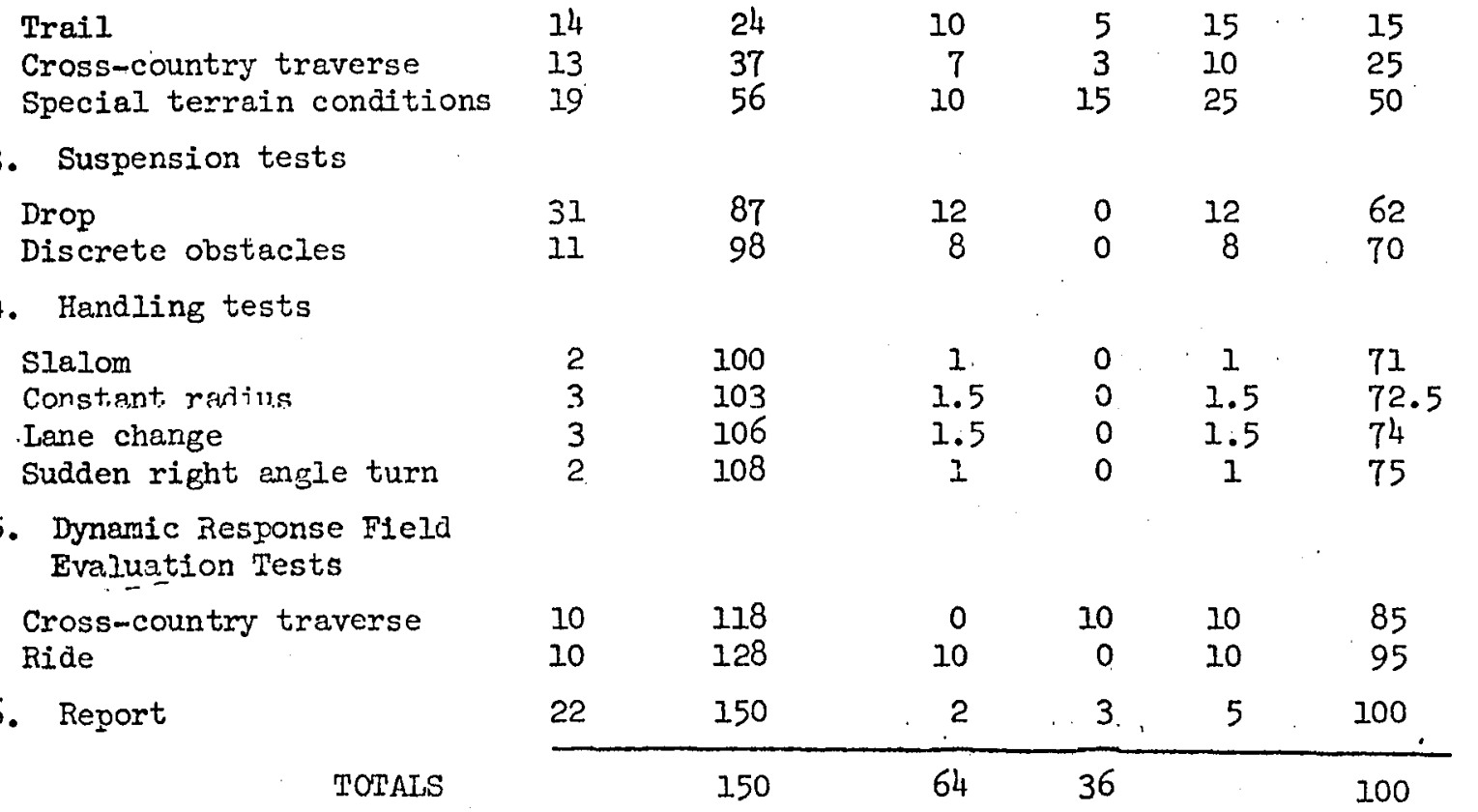


TABL:AII

SUMMARY OF TIME SCHEDULE AND COSTS

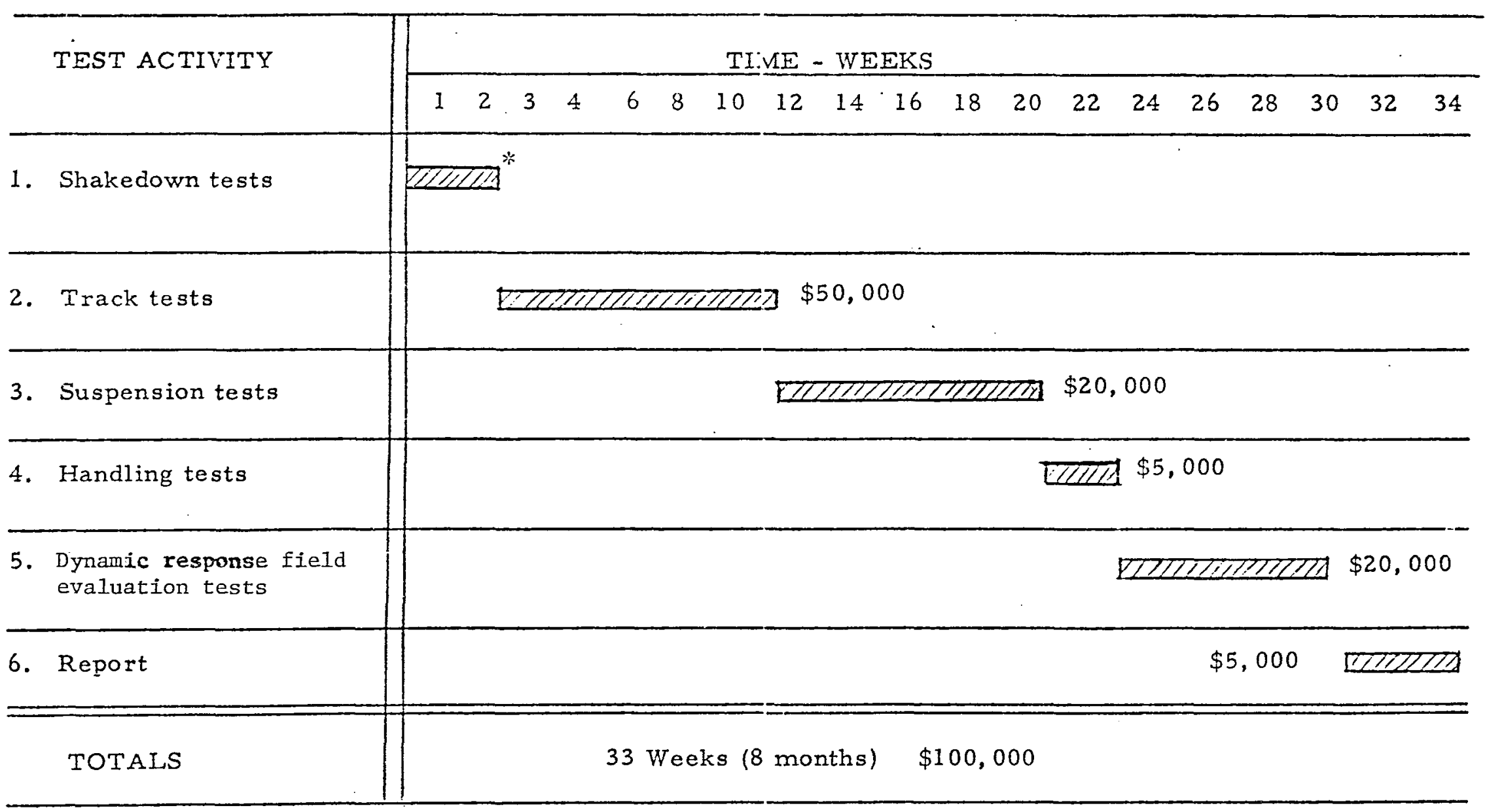

*Previously authorized funds to be used. 
Unclassified

Security Classification

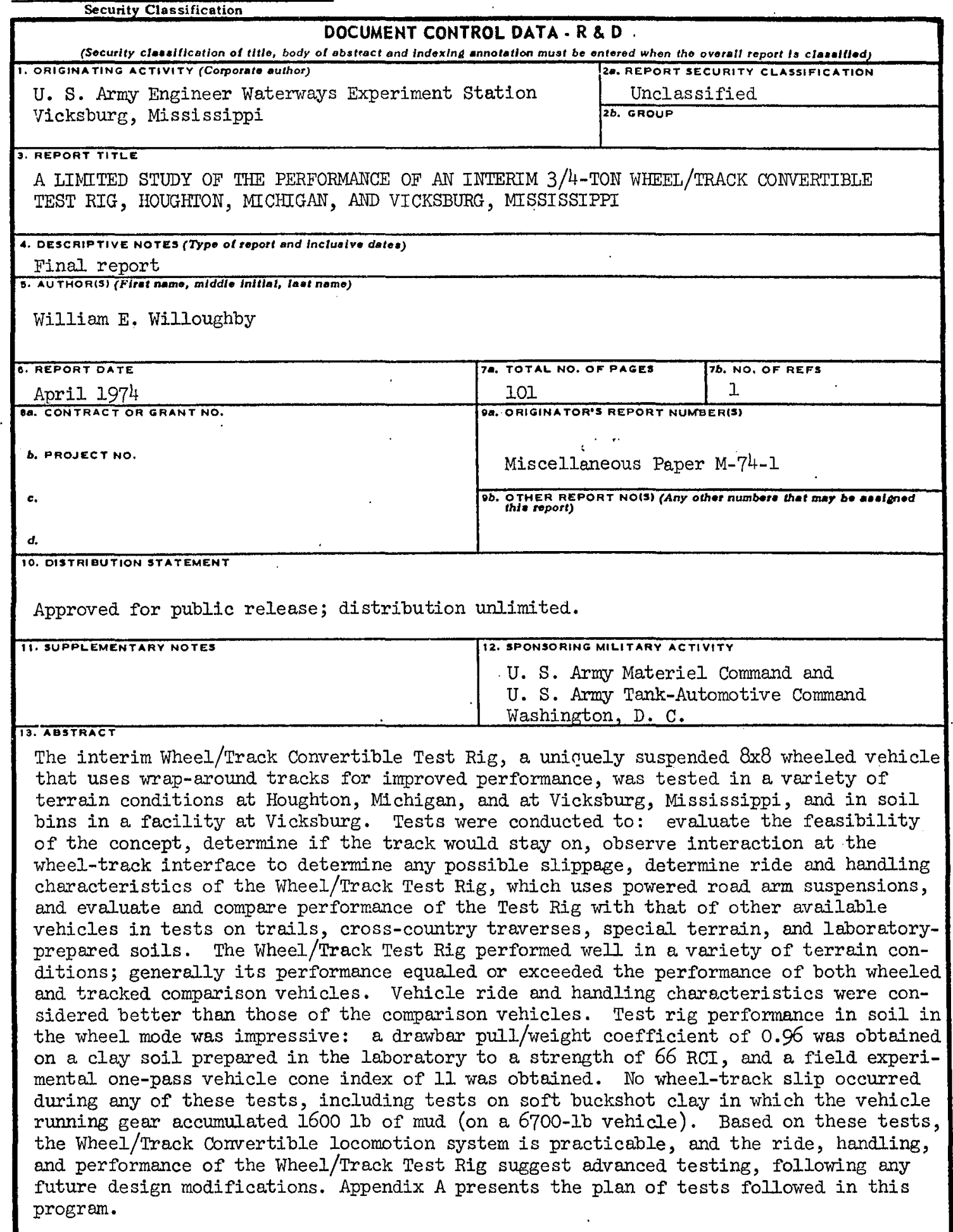

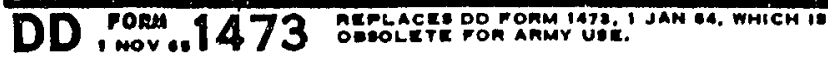

Unclassified

Security Clessification 


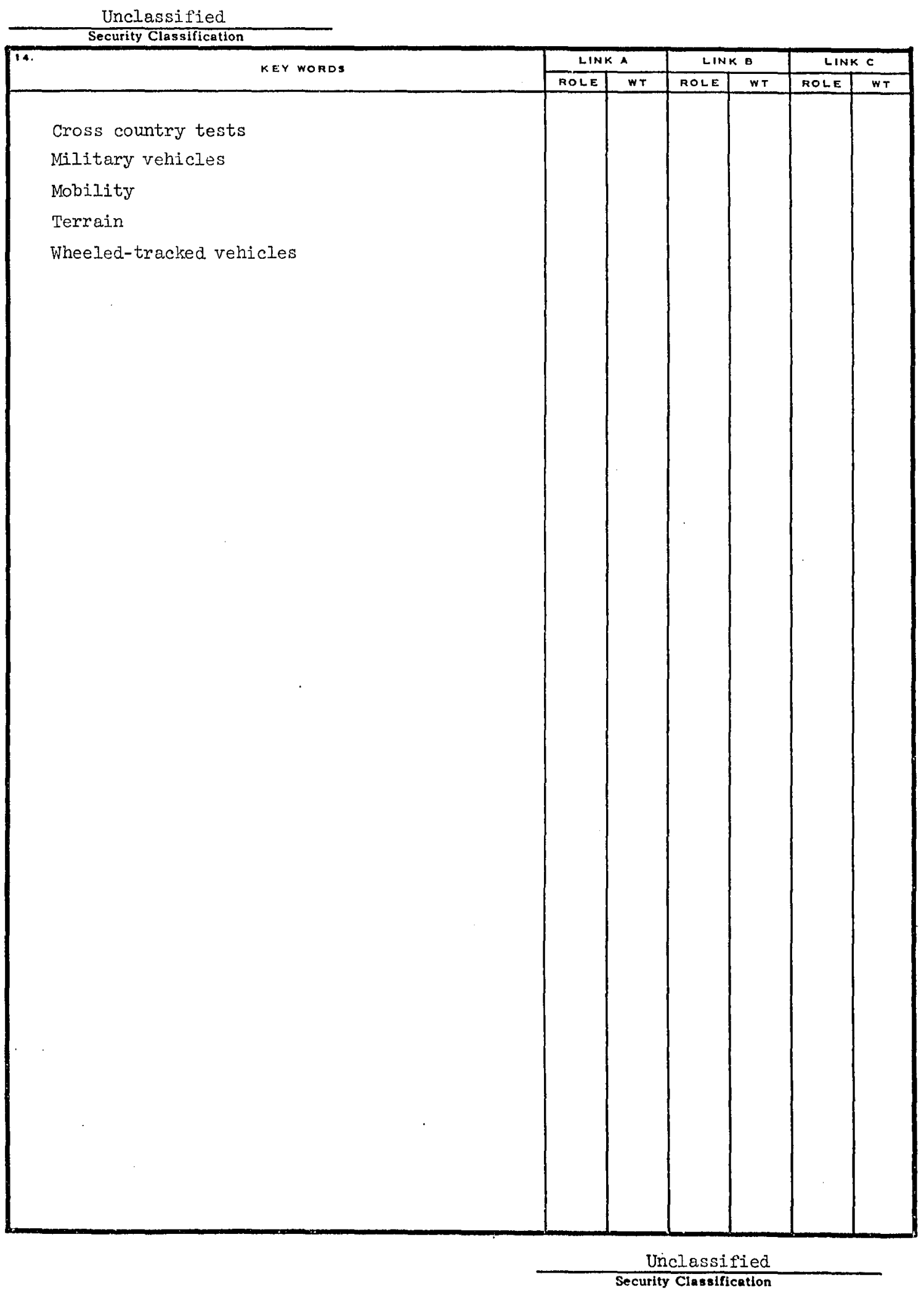


In accordance with ER 70-2-3, paragraph $6 c(1)(b)$, dated 15 February 1973, a facsimlle catalog card in Library of Congress format is reproduced below.

Willoughby, William $\mathrm{E}$

A Iimited study of the performance of an interim 3/4-ton wheel/track convertible test $r 1 g$, Houghton, Michigan, and Vicksburg, Mississippl, by W. E. Willoughby. Vicksburg, U.S. Army Engineer Waterways Experiment Station, 1974

I v. (various pagings) illus. $27 \mathrm{~cm}$. (U. S. Waterways Experiment Station. Miscellaneous paper M-74-1)

Sponsored by U. S. Army Materiel Command and U. S. Army Tank-Automotive Command.

1. Cross country tests. 2. Military vehicles. 3. Mobility. 4. Terrain. 5. Wheeled-tracked vehicles. I. U. S. Army Materiel Comand. II. U. S. Arny Tani-Automotive Command. (Series: U. S. Waterways Experlment Station, Vicksburg, Miss. Miscellaneous paper $\mathrm{M}-7 \mathrm{4}-1$ )

TA7. W34m no.M-74-1 
